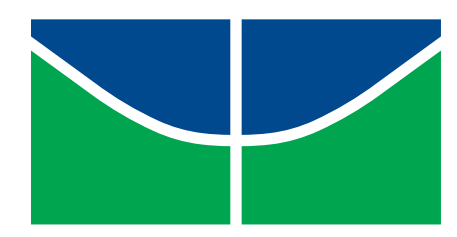

\author{
Universidade de Brasília \\ Instituto de Ciências Exatas \\ Departamento de Matemática
}

\title{
Análise de Qualidade do Ensino nas Escolas Públicas do Distrito Federal Utilizando Prova Brasil:Uma Aplicação de Análise por Envoltória de Dados
}


Ficha catalográfica elaborada automaticamente, com os dados fornecidos pelo(a) autor(a)

Hung, Augusto

Análise de Qualidade do Ensino nas Escolas Públicas do Distrito Federal Utilizando Prova Brasil: Uma Aplicação de Análise por Envoltória de Dados / Augusto Hung; orientador Rui Seimetz. -Brasília, 2016.

$$
94 \mathrm{p} \text {. }
$$

Dissertação (Mestrado - Mestrado Profissional em Matemática) -- Universidade de Brasília, 2016.

1. Escolas Públicas do Distrito Federal. 2. Eficiência. 3. Conglomerado. 4. DEA. I. Seimetz, Rui, orient. II. Título. 


\section{Augusto Hung}

Análise de Qualidade do Ensino nas Escolas Públicas do Distrito Federal Utilizando Prova Brasil:Uma Aplicação de Análise por Envoltória de Dados

Dissertação apresentada ao Departamento de Matemática da Universidade de Brasília, como parte dos requisitos para a obtenção do grau de

\section{Mestre}

Orientador: Prof. Dr. Rui Seimetz

Brasília

2016 


\section{Análise de Qualidade do Ensino nas Escolas Públicas do Distrito Federal} Utilizando Prova Brasil: Uma Aplicação de Análise por Envoltória de Dados.

\section{por}

\section{Augusto Hung *}

Dissertação apresentada ao Departamento de Matemática da Universidade de Brasília, como parte dos requisitos do "Programa" de Mestrado Profissional em Matemática em Rede Nacional - PROFMAT, para obtenção do grau de

\section{MESTRE}

Brasília, 30 de março de 2016.

Comissão Examinadora:
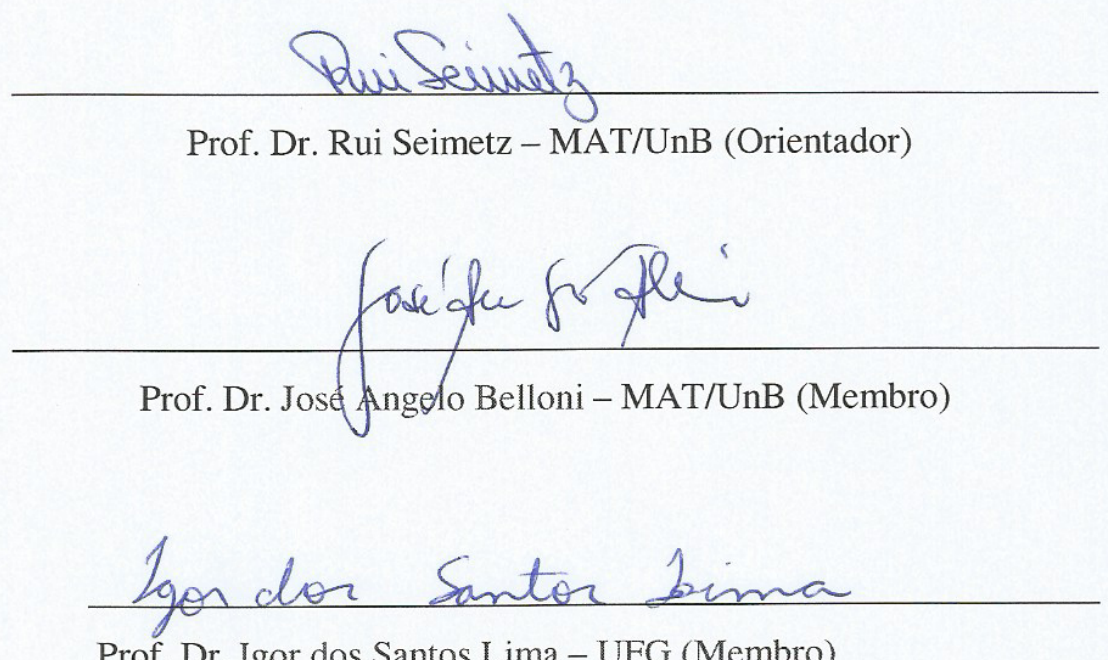

* O autor foi bolsista CAPES durante a elaboração desta dissertação 


\section{Dedicatória}

Dedico este trabalho à minha família, pelo amor que sempre me afertaram e pelo apoio incondicional.

À vocês o meu amor e reconhecimento eterno... 


\section{Agradecimentos}

Serei eternamente grato pelo amor, apoio e incentivo da minha família, pessoas que sempre lutaram para que eu pudesse realizar meus sonhos. Sem a força de vocês eu jamais conseguiria chegar até aqui.

Agradeço ao Professor Doutor José Angelo Belloni, que foi meu orientador na graduação de Estatística. Mesmo concluído o curso de Estatística, ele continuou a me dar suporte neste trabalho. Ao Professor Doutor Rui Seimetz pela paciência, sugestões e dedicação nesse trabalho.

Enfim, obrigado a todos aqueles que participaram e torceram para a concretização de mais um dos meus sonhos. 


\section{Resumo}

As escolas públicas do Distrito Federal possuem a mesma fonte financeira, os alunos possuem o mesmo tipo de acesso, os professores possuem a mesma carreira. Porém os resultados da Prova Brasil são diferentes. Com o intuito de analisar a qualidade do ensino utilizando os resultados da Prova Brasil, as escolas foram divididas em dois grandes grupos que são Ensino Fundamental I e II porque estão em anos diferentes que é $5^{\circ}$ ano e $9^{\circ}$ ano, sem esquecer que cada um desses anos faz provas diferentes. Cada grupo foi dividido em dois conglomerados que são escolas que estão localizadas em regiões mais ricas com mais infraestrutura e em regiões mais pobres com menos infraestrutura. Em seguida aplicou-se o modelo DEA (Análise por Envoltória de Dados) nestes quatro grupos para obter-se informações de quais são as eficientes. Neste sentido, identificam-se ações e estratégia para que as escolas ineficientes sejam projetadas para o patamar de eficiência.

Palavras-chave: Ensino Escolas Públicas do DF, Eficiência, Conglomerado, DEA. 


\begin{abstract}
The public schools of the Federal District have the same financial source, students have the same type of access, teachers have the same career. But the results of the Prova Brasil are different. Thus, they were divided into two groups which are Elementary School I and II because they are in different years that are $5^{\circ}$ and $9^{\circ}$ grades, without forgetting that each of those years has different tests. Thus, each of the group was divided into two clusters which are schools that are located in richer regions with more infrastructure and in poorer areas with less infrastructure. Then it was applied the DEA (Data Envelopment Analysis) model in these four groups to discover eficiente schools. Inefficient schools will be lifted up to the level of efficiency.
\end{abstract}

Keywords: The public schools of the Federal District, efficiency, cluster, DEA . 


\section{Sumário}

\begin{tabular}{ll}
\hline Introdução & 1
\end{tabular}

$1 \quad$ Referencial teórico 5

$1.1 \quad$ Análise por Envoltória de Dados (DEA) . . . . . . . . . . . . . 5

$1.1 .1 \quad$ Eficiência Produtiva . . . . . . . . . . . . . . . . . 6

1.1.2 DEA e a Eficiência Produtiva das Escolas . . . . . . . . . . . . 6

1.1 .3 Modelo CCR . . . . . . . . . . . . . . . . . . . . . . . . 9 9

1.1 .4 Modelo BCC . . . . . . . . . . . . . . . . . . . . 11

1.1 .5 DEA e a Análise de Dados . . . . . . . . . . . . . . . . . . 12

1.1 .6 Seleção de Variáveis em DEA . . . . . . . . . . . . . . . . . . . 14

1.2 Análise de Conglomerados . . . . . . . . . . . . . . . . . . . 16

1.3 Análise de Componentes Principais . . . . . . . . . . . . . . . . . . . . 18

1.4 Coeficiente de Correlação de Pearson . . . . . . . . . . . . . . . . . . . 20

\begin{tabular}{|lll}
2 & Metodologia & 21
\end{tabular}

$2.1 \quad$ Metodologia . . . . . . . . . . . . . . . . . . . 21

3 Aplicação do Modelo DEA em Escolas Públicas do DF 22

$3.1 \quad$ Análise Exploratória dos Dados . . . . . . . . . . . . . . . . . . . 22

3.2 Análise de Componentes Principais . . . . . . . . . . . . . . . . . . . . 32

3.3 Seleção das escolas . . . . . . . . . . . . . . . . . . . . . . . 35

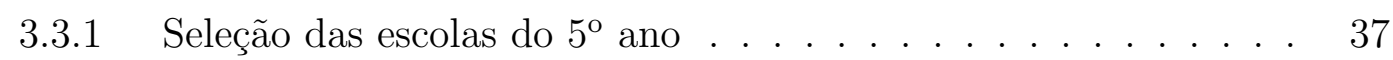

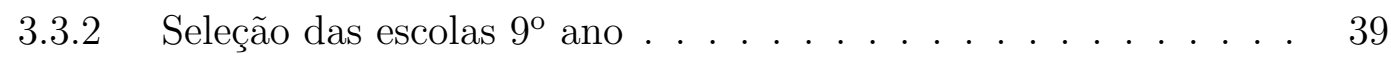

4 Modelo DEA $\quad 42$

$4.1 \quad$ Modelo DEA $55^{\circ}$ ano Conglomerado $1 . \ldots \ldots \ldots$. . . . . . . . . 42

4.2 Modelo DEA - $5^{\circ}$ ano Conglomerado 2 e $9^{\circ}$ ano Conglomerados 1 e 2.45

$4.3 \quad$ Aplicação dos Modelos DEA . . . . . . . . . . . . . . . . . . . . . 45

$4.3 .1 \quad 5^{\circ}$ ano Conglomerado 1 . . . . . . . . . . . . . . . . . 45

$4.3 .2 \quad 5^{\circ}$ ano Conglomerado 2 . . . . . . . . . . . . . . . 47 
$4.3 .3 \quad 5^{\circ}$ ano comparando Conglomerado 1 e $2 \ldots \ldots$. . . . . . . 48

$4.4 \quad 9^{\circ}$ ano Conglomerado $1 \ldots \ldots \ldots \ldots$

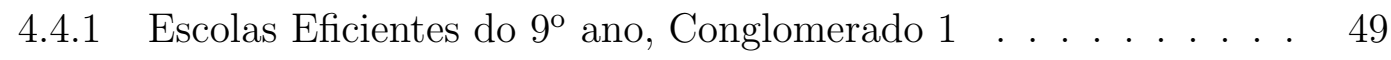

$4.4 .2 \quad 9^{\circ}$ ano, Conglomerado $2 \ldots \ldots \ldots \ldots$

4.4 .3 Comparando as Escolas Eficientes do Conglomerado 1 e 2 . . . 51

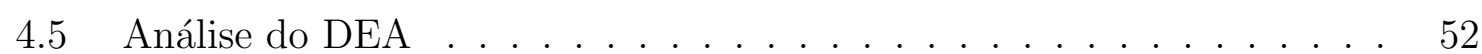

5 Considerações Finais 53

$\begin{array}{ll}\text { Referências } & 56\end{array}$

\begin{tabular}{ll}
\hline A Apêndice & 58
\end{tabular}

\begin{tabular}{ll}
\hline B Apêndice & 71
\end{tabular} 


\section{Lista de Figuras}

$1.1 \quad$ DEA - problemas dos multiplicadores. . . . . . . . . . . . . . . . 8

1.2 DEA - problemas do envelopamento. . . . . . . . . . . . . . 8

1.3 DEA - Medidas radiais de eficiência produtiva. . . . . . . . . . . . . . . 9

1.4 DEA - Modelo CCR orientado para consumo. . . . . . . . . . . . . . . 10

1.5 DEA - Modelo CCR orientado para a produção. . . . . . . . . . . . . . 10

1.6 DEA - Etapas da projeção para a fronteira. . . . . . . . . . . . . . . 11

1.7 DEA - Modelo BCC orientado para a produção. . . . . . . . . . . . . . 12

$1.8 \quad$ Fluxograma descritivo do procedimento de Norman e Stoker. . . . . . . . 15

3.1 Nota da Prova Brasil do $5^{\circ}$ ano da Escola Pública do DF. . . . . . . . . . 24

3.2 Média Ponderada da Prova Brasil do $5^{\circ}$ ano Escola Pública do DF. . . 24

3.3 Padronização da Nota do $5^{\circ}$ ano da Prova Brasil da Escola Pública do

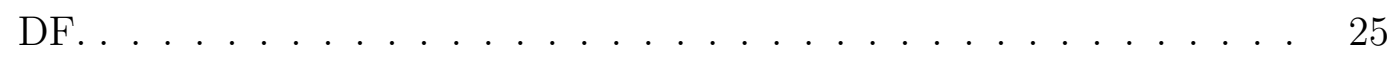

3.4 Taxa de Aprovação $5^{\circ}$ ano Escola Pública do Distrito Federal. . . . . . 26

3.5 Nota da Prova Brasil do $9^{\circ}$ ano da Escola Pública do DF. . . . . . . . . 27

3.6 Média Ponderada da Prova Brasil, 9 ano Escola Pública do DF. . . . . 27

3.7 Padronização da Nota do $9^{\circ}$ ano da Prova Brasil das Escolas Públicas do DF. . . . . . . . . . . . . . . . . . 28

3.8 Taxa de Aprovação $9^{\circ}$ ano Escola Pública do DF. . . . . . . . . . . . . 28

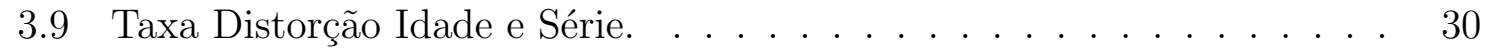

3.10 Taxa de Abandono por Série. . . . . . . . . . . . . . . . . . . 30

3.11 Titulação dos Docentes do $1^{\circ}$ a $5^{\circ}$ ano em 2013. . . . . . . . . . . . . . 31

3.12 Título do Docente $6^{\circ}$ a $9^{\circ}$ ano em 2013. . . . . . . . . . . . . . . . . 31

3.13 Análise de Componentes Principais Fator 1 e 2 do $5^{\circ}$ ano. . . . . . . . . 33

3.14 Análise de Componentes Principais Fator 1 e 2 do $9^{\circ}$ ano. . . . . . . . . 34

3.15 Dendograma $5^{\circ}$ ano. . . . . . . . . . . . . . . . 37

3.16 Média Padronizada das Variáveis Separadas por Conglomerado 1 e 2. . 37

3.17 Box-Plot de Taxa de Aprovação Segundo Conglomerado 1 e 2. . . . . . 38 
3.18 Nota da Prova Brasil segundo Conglomerados 1 e 2. . . . . . . . . . . . 38

3.19 Box-Plot da Prova Brasil de Português, Matemática e Média dos dois em 2013. . . . . . . . . . . . . . . . . . . . . . . . . . . . . . 39

3.20 Dendograma $9^{\circ}$ ano. . . . . . . . . . . . . . . . . . . . . . . . . . 40

3.21 Média Padronizada das Variáveis Separados por Conglomerado 1 e 2. . $\quad 40$

3.22 Box-Plot de Taxa de Aprovação Segundo Conglomerado 1 e 2. . . . . . 41

3.23 Nota da Prova Brasil Segundo Conglomerado 1 e 2. . . . . . . . . . . . 41

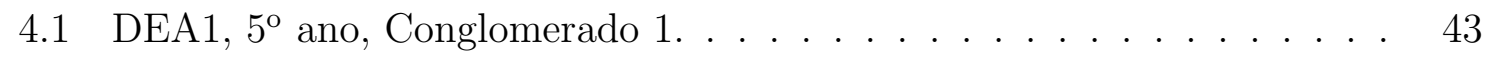

4.2 DEA 2, Conglomerado $1,5^{\circ}$ ano . . . . . . . . . . . . . . 44

4.3 DEA 2, Conglomerado $1,5^{\circ}$ ano . . . . . . . . . . . . . . . . . . . 46

4.4 EC $209 \mathrm{Sul}$ ineficiente para atingir a eficiência. . . . . . . . . . . . . . . 46

4.5 DEA 2, Conglomerado 2, $5^{\circ}$ ano $\ldots \ldots \ldots$. . . . . . . . . . . . 47

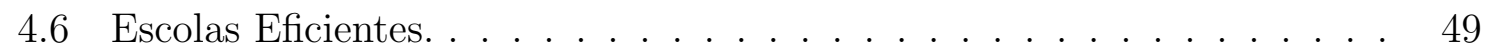

4.7 DEA 2, $9^{\circ}$ ano, Conglomerado $1 . \ldots \ldots \ldots \ldots$

4.8 Escolas Eficientes $9^{\circ}$ ano, Conglomerado 2. . . . . . . . . . . . . . . . . 51

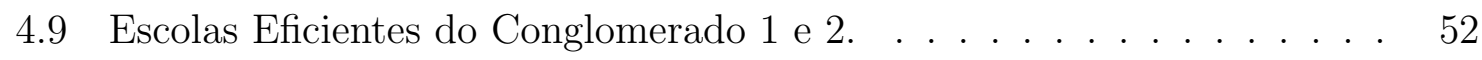




\section{Lista de Tabelas}

3.1 Número de Escolas da Rede Pública do DF por situação urbana e rural segundo CRE em 2013. . . . . . . . . . . . . . . . . . . . . . . . 23

3.2 Número de Escolas no Ensino Fundamental por nível de ensino segundo a CRE em 2013. . . . . . . . . . . . . . . . . . . . . . . . . . . . . 23

3.3 Titulação dos Professores das Escolas Públicas do GDF em 2013. . . 30

3.4 Recursos e Equipamentos Pedagógicos. . . . . . . . . . . . . . . . . . . . 32

3.5 Autovalores $5^{\circ}$ ano. . . . . . . . . . . . . . . . . . . . . . . . 33

3.6 Autovalores $9^{\circ}$ ano. . . . . . . . . . . . . . . . . . . . . . . . . . . . . . . . . 34

4.1 Escolas eficientes do DEA1. . . . . . . . . . . . . . . . . . . . . . . . . . 43

4.2 Escolas eficientes DEA $2,5^{\circ}$ ano, Conglomerado 1. . . . . . . . . . . . . 44

4.3 Escolas eficientes DEA 2, $5^{\circ}$ ano, Conglomerado 1. . . . . . . . . . . . 45

4.4 DEA 2, $5^{\circ}$ ano, Conglomerado 2. . . . . . . . . . . . . . . . 47

4.5 Escolas Eficientes do $5^{\circ}$ ano, Conglomerado 1. . . . . . . . . . . . . . . 48

4.6 Escolas Eficientes do $9^{\circ}$ ano, Conglomerado 1. . . . . . . . . . . . . . . 49

$4.7 \quad$ Escolas Eficientes $9^{\circ}$ ano, Conglomerado 2. . . . . . . . . . . . . . . . . 50

4.8 Escolas Eficientes entre Conglomerado 1 e $2 . \quad$. . . . . . . . . . . . . . 51

A.1 Nível de Desempenho dos alunos segundo a Prova Brasil. . . . . . . . . 58

B.1 Análise de Componente Principal $5^{\circ}$ ano. . . . . . . . . . . . . . . . . . 72

B.2 Análise de Componentes Principais do $9^{\circ}$ ano. . . . . . . . . . . . . . . 72

B.3 Correlação $5^{\circ}$ ano Conglomerado 1. . . . . . . . . . . . . . . . . . . . 73

B.4 Escolas do $5^{\circ}$ ano Conglomerado 1 para o patamar de eficiência. . . . . 74

B.6 Escolas Eficientes segundo Escolas $5^{\circ}$ ano Conglomerado 1. 


\section{Notação}

$\begin{array}{ll}\text { DEA } & \text { Análise por Envoltória de Dados } \\ \text { CCR } & \text { Charnes, Cooper e Rhodes (Retorno Constante a Escala) } \\ \text { BCC } & \text { Banker, Charnes e Cooper (Retorno Variável a Escala) } \\ \text { DMU } & \text { Decision Making Unity - Escolas avaliadas } \\ \text { s/a } & \text { Sujeito a } \\ s_{j}^{+} & \text {Folga na produção } \\ s_{j}^{-} & \text {Folga no consumo } \\ \varepsilon & \text { Penalização pela folga } \\ t r & \text { Traço } \\ I & \text { Matriz Identidade } \\ S & \text { Matriz de Variância e Covariância } \\ l & \text { Multiplicador de Lagrange } \\ E\left(Y_{i}\right) & \text { Esperaça de } Y_{i} \\ \text { diag } & \text { Diagonal } \\ \text { cov } & \text { Covariância } \\ \text { corr } & \text { Correlação } \\ \text { var } & \text { Variância } \\ \mathbb{R} & \text { Conjunto dos Números Reais } \\ \bar{x} & \text { Média da variável } x \\ \bar{y} & \text { Média da variável y } \\ \text { outliers } & \text { Pontos discrepantes ao demais } \\ \text { benchmarks } & \text { Escolas Eficientes } \\ i s o q u a n t a & \text { igual quantidade e pode ser definida como sendo uma linha } \\ & \text { na qual todos os pontos representam combinações dos fato- } \\ & \text { res que indicam a mesma quantidade produzida. } \\ & \end{array}$




\section{Introdução}

No Brasil, os pais matriculam seus filhos na escola pública mais próxima de sua residência. Uma característica é que as de diferentes bairros são semelhantes em termos da taxa de aprovação, infraestrutura e perfil sócio econômico. Porém, elas apresentam resultados díspares em relação a provas padronizadas.

Sabemos como fazer uma escola de qualidade, uma escola boa. Há inclusive escolas públicas assim no Brasil, algumas centenas delas, ou talvez poucos milhares. São escolas de prestígio, de alto padrão, onde o ensino é de qualidade, os alunos estudam e aprendem e os resultados são elevados. São escolas militares, colégios de aplicação e unidades estaduais ou municipais que possuem as mesmas características. Mas essas escolas são poucas - uma pequena fração entre as mais de 120.000 unidades urbanas de ensino fundamental no país.

Em geral não aprendemos a fazer aquilo que os países desenvolvidos sempre fizeram: manter um padrão de qualidade de ensino. E quando o nível deste cai, há mecanismos para trazer a escola de volta. Resultado: embora os pais tendem a matricular seus filhos na escola do bairro, os responsáveis sabem que o ensino oferecido ali é semelhante ao proporcionado por unidades de outros bairros. E sabem que se seus filhos se esforçarem também obterão bons resultados.

Manter uma rede de escolas de padrão não significa que todas as unidades são idênticas, que recebem os mesmos recursos, que são $100 \%$ padronizadas. Ao contrário, para ter resultados semelhantes, as escolas precisam de recursos distintos pois algumas têm mais problemas e desafios do que outras. Para promover a igualdade é necessário tratar desigualmente os desiguais. Escolas que caem no desempenho recebem ajuda extra; escolas com maior número de alunos com dificuldade de aprendizado recebem mais e melhores recursos, e assim por diante.

Esta pesquisa apresenta uma metodologia para avaliar a qualidade das escolas vinculadas à Secretaria de Educação do Distrito Federal sob o ponto de vista do desempenho dos seus alunos na Prova Brasil e considerando a infraestrutura disponível.

A Prova Brasil e o Sistema Nacional de Avaliação da Educação Básica 
(SAEB) são avaliações para diagnóstico, em larga escala, desenvolvidas pelo Instituto Nacional de Estudos e Pesquisas Educacionais Anísio Teixeira (INEP/MEC). Têm o objetivo de avaliar a qualidade do ensino oferecido pelo sistema educacional brasileiro a partir de testes padronizados e questionários socioeconômicos. [15].

Nos testes aplicados na quarta e oitava séries (quinto e nono ano) do Ensino Fundamental, os estudantes respondem a itens (questões) de Língua Portuguesa, com foco em leitura, e Matemática, com foco na resolução de problemas. No questionário socioeconômico, os estudantes fornecem informações sobre fatores de contexto que podem estar associados ao desempenho. Por esta razão, deve-se separar em dois grandes grupos por terem seriados e provas diferentes por serem impossível de compará-las. [15].

Os professores e diretores das turmas e escolas avaliadas também respondem a questionários que coletam dados demográficos, perfil profissional e de condições de trabalho.

A partir das informações do SAEB e da Prova Brasil, o MEC e as secretarias estaduais e municipais de Educação podem definir ações voltadas ao aprimoramento da qualidade da educação no país e a redução das desigualdades existentes, promovendo, por exemplo, a correção de distorções e debilidades identificadas e direcionando seus recursos técnicos e financeiros para áreas identificadas como prioritárias.

As médias de desempenho nessas avaliações também subsidiam o cálculo do Índice de Desenvolvimento da Educação Básica (IDEB), ao lado das taxas de aprovação nessas esferas.

Além disso, os dados também estão disponíveis para toda a sociedade que, a partir dos resultados, pode acompanhar as políticas implementadas pelas diferentes esferas de governo. No caso da Prova Brasil, ainda pode ser observado o desempenho específico de cada rede de ensino e do sistema como um todo das escolas públicas urbanas e rurais do país. Em [15] tem-se informações completas da Prova Brasil e SAEB.

Para este trabalho informações relativas a infraestrutura física e de pessoal das escolas foram obtidas no Censo Escolar de 2013.

O Censo Escolar é um levantamento de dados estatístico-educacionais de âmbito nacional realizado todos os anos e coordenado pelo INEP. Ele é feito com a colaboração das secretarias estaduais e municipais de Educação e com a participação de todas as escolas públicas e privadas do país.

Trata-se do principal instrumento de coleta de informações da educação básica, que abrange as suas diferentes etapas e modalidades: ensino regular (Educação Infantil e Ensinos Fundamental e Médio), Educação Especial e Educação de Jovens e Adultos (EJA). O Censo Escolar coleta dados sobre estabelecimentos, matrículas, funções docentes, movimento e rendimento escolar. 
Essas informações são utilizadas para traçar um panorama nacional da Educação Básica e servem de referência para a formulação de políticas públicas e execução de programas na área da educação, incluindo os de transferência de recursos públicos como merenda e transporte escolar, distribuição de livros e uniformes, implantação de bibliotecas, instalação de energia elétrica, Dinheiro Direto na Escola e Fundo de Manutenção e Desenvolvimento da Educação Básica e de Valorização dos Profissionais da Educação (FUNDEB).

Além disso, os resultados obtidos no Censo Escolar sobre o rendimento (aprovação e reprovação) e movimento (abandono) escolar dos alunos do Ensino Fundamental e Médio, juntamente com outras avaliações do Inep (SAEB e Prova Brasil), são utilizados para o cálculo do Índice de Desenvolvimento da Educação Básica (IDEB), indicador que serve de referência para as metas do Plano de Desenvolvimento da Educação (PDE), do Ministério da Educação. [15].

As Escolas Públicas do Governo do Distrito Federal pertencem ao mesmo sistema de ensino; os professores têm a mesma carreira; o acesso dos alunos ao sistema é o mesmo e os recursos provêm da mesma fonte. As escolas têm alguma autonomia na alocação de parte destes recursos e na execução do processo pedagógico. Porém, observou-se diferenças significativas no desempenho dos alunos avaliados na Prova Brasil.

Para mensuração de desempenho das escolas utilizou-se a Análise por Envoltória de Dados, técnica que avalia a eficiência com que a escola transforma os recursos disponíveis (professores, titulação do professor, alunos matriculados, equipamentos) em resultados (desempenho da Prova Brasil, Taxa de Aprovação).

A técnica DEA considera múltiplos recursos e múltiplos resultados sem exigir que se conheça a priori um conjunto de taxas de substituição (pesos) entre as variáveis nem a especificação da forma funcional das relações entre os recursos e os resultados. Estas características são particularmente vantajosas na avaliação de instituições cujos fatores de produção não estão diretamente submetidos a valores de mercado ou outras medidas cardinais de importância, como, por exemplo, escolas.

Apesar de pertencerem ao mesmo sistema de ensino, as Escolas do Distrito Federal diferenciam-se com relação a infraestrutura disponível além de localizarem-se em regiões administrativas com situações socioeconômicas bastante distintas.

Para garantir a comparabilidade entre as escolas, condição necessária para a aplicação da DEA, classificou-se as escolas em grupos com características semelhantes, utilizando Análise de Conglomerados (Cluster Analysis).

Em cada segmento analisado (Ensino Fundamental I e Ensino Fundamental II) identificou-se dois conglomerados com características distintas, uns formados por escolas com boas condições de infraestrutura localizadas em regiões de rendas mais altas e outras com piores condições de infraestrutura em regiões de renda mais baixa. 
Aplicou-se DEA a cada um dos conglomerados em cada segmento, classificando, assim, as escolas em eficientes e ineficientes e identificando possibilidade de melhoria para as ineficientes.

Num segundo momento comparou-se as escolas de ambos os conglomerados em cada segmento, observando-se a permanência de escolas menos equipadas como eficientes. Essas escolas constituem referências de bom desempenho dos alunos mesmo em condições desfavoráveis, e devem ser objeto de investigações futuras.

A projeção das escolas ineficientes nas fronteiras de eficiência permitiu, não só mensurar as ineficiências, mas, também, identificar ações e estratégias para aumentar a produtividade.

No presente trabalho, foram estudadas "características" de Escolas Públicas do DF tendo as variáveis qualitativas como internet, sala de professores, laboratório de informática, laboratório de ciência entre outros. E também as variáveis quantitativas que são nota da Prova Brasil, números de professores, alunos, televisores, e outros recursos pedagógicos. Tem por objetivo avaliar a qualidade da educação das Escolas Públicas do Distrito Federal, fazendo a análise de recursos como financeiro, patrimonial, humano e fazer uma dualidade entre a Prova Brasil e a quantidade de alunos aprovados no Ensino Fundamental.

Além disso, tem como objetivos específicos:

- Realizar uma análise descritiva do Sistema Público de Ensino do Distrito Federal;

- Apresentar uma metodologia para avaliar o desempenho das Escolas Públicas do DF sob o ponto de vista da eficiência produtiva, considerando indicadores de qualidade do ensino;

- Identificar estratégias e ações que conduzam as Escolas Ineficientes ao patamar da eficiência respeitando seus projetos pedagógicos e especificidades ambientais. 


\section{Capítulo 1}

\section{Referencial teórico}

\subsection{Análise por Envoltória de Dados (DEA)}

A tese de Doutorado de Edward Rhodes, orientado por W.W. Cooper, [13], deu origem à Análise por Envoltória de Dados (DEA), na qual o problema abordado foi o desenvolvimento de um método para comparar a eficiência de escolas públicas DMU's levando em consideração os outputs (Resultados) segundo Charnes et al., [7]. Esta tese teve como objetivo desenvolver um modelo para estimar a eficiência técnica, na qual não se utilizava pesos para as variáveis, tanto para os inputs (Recursos) quanto para os outputs (Resultados) e sem converter todas as variáveis em valores econômicos comparáveis (Modelo CCR).

O que diferencia o método DEA dos demais métodos baseados em avaliação puramente econômica é que estes necessitam converter todos os RECURSOS e RESULTADOS em unidades monetárias. O DEA trata simultaneamente múltiplos recursos e múltiplos resultados sem exigir, a priori, nenhuma estrutura de pesos entre eles.

Além disso, DEA considera outliers, desvios em relação ao comportamento médio, como possíveis benchmarks a serem tomados como referência pelas demais DMU's e avalia cada observação individual com o objetivo de determinar uma fronteira linear por partes, que compreende o conjunto de DMU's Pareto-Eficiente.

DEA é uma técnica utilizada por profissionais de várias áreas do conhecimento com enfoques de interesses diversos, segundo [9].

Econometristas consideram DEA como uma técnica para estimação de uma função de produção empírica. Matemáticos a consideram uma metodologia para determinar soluções não dominadas em um problema com múltiplos critérios. E para os engenheiros industriais, DEA constitui uma ferramenta para o aumento e melhoria da produtividade. 


\subsubsection{Eficiência Produtiva}

Sob aspectos econômicos e de produtividade material a eficiência na produção se relaciona com a capacidade que uma organização tem de transformar os recursos no máximo de resultados.

A eficiência produtiva é a capacidade de se evitar desperdícios afim de produzir a maior quantidade de resultados que os recursos utilizados permitem e utilizar o mínimo possível de recursos necessários à determinada produção.

Um modelo de avaliação de eficiência conhecido como modelo CCR (Retorno Constantes a Escalas - CRS) foi proposto por Charnes, Cooper e Rhodes (1978), dando origem a um complexo de modelos e técnicas de construção de fronteiras de produção e medidas de eficiência relativa, conhecida como Análise por Envoltória de Dados (DEA).

O modelo conhecido como BCC (Retorno Variáveis a Escalas- VRS) desenvolvido por Banker, Charnes e Cooper em 1984, é uma medida de eficiência técnica, isolando o componente da eficiência produtiva total que é devido a afastamentos da escala mais produtiva (eficiência de escala) do componente de eficiência técnica propriamente dita (eficiência técnica), segundo [3].

O DEA é um método largamente usado para estimar as eficiências de unidades organizacionais que possuem as mesmas características e que usam um mesmo conjunto de recursos para produzir um mesmo conjunto de resultados, por meio de processos tecnológicos semelhantes.

O modelo DEA considera valores observados de recursos utilizados e resultados alcançados para construir um espaço de possibilidades de produção, delimitado por uma fronteira linear por partes definida a partir dos melhores desempenhos. As unidades que se posicionam sobre essa fronteira são ditas eficientes, enquanto a ineficiência das demais é mensurada a partir da medida da distância à fronteira. Essa distância determina a possibilidade de aumento na produção.

DEA é adequado quando não é possível ou apropriado unir recursos e resultados em uma única unidade.

\subsubsection{DEA e a Eficiência Produtiva das Escolas}

A eficiência produtiva mensurada pela técnica DEA será conceituada formalmente. Considere uma escola como um sistema de produção múltipla, que transforma $N$ itens de recursos, representados por um vetor de quantidades $x=\left(x_{1}, x_{2}, \ldots\right.$, $\left.x_{N}\right) \in \mathbb{R}_{+}^{N}$, em $M$ itens de resultados cujas quantidades estão representadas em um vetor $y=\left(y_{1}, y_{2}, \ldots, y_{M}\right) \in \mathbb{R}_{+}^{M}$, determinando um plano de produção descrito pelo vetor $(x, y) \in \mathbb{R}_{+}^{N+M}$, onde $\mathbb{R}$ representa o conjunto dos números reais e $M$ e $N$ são números inteiros positivos. 
Supor que foram observados $K$ planos de produção $\left(x_{i}, y_{i}\right), i=1,2, \ldots$, $k$, realizados por $K$ escolas similares, que foram denotados por $D M U^{\prime} s$ (Decision Making Unity). O $x_{k i}$ é a quantidade do recurso $i(i=1,2, \ldots, N)$ utilizada e $y_{k j}$ é a quantidade do resultado $j(j=1,2, \ldots, M)$ produzida pela $D M U_{k}$. Neste trabalho, a escola avaliada será simbolizada por $D M U_{0}$, representada nos modelos DEA pelo plano de produção $\left(x_{0}, y_{0}\right)$. O desempenho resultante do $D M U_{0}$ é dado pela expressão algébrica

$$
E_{0}=\frac{\sum_{j=1}^{M} q_{j} y_{0 j}}{\sum_{i=1}^{N} p_{i} x_{0 i}}
$$

onde $p=\left(p_{1}, p_{2}, \ldots, p_{N}\right)$ e $q=\left(q_{1}, q_{2}, \ldots, q_{M}\right)$ são os vetores de pesos utilizados para a agregação dos recursos e dos resultados da $D M U_{0}$, respectivamente. O desempenho resultante, $E_{0}$, é uma medida da produtividade da $D M U_{0}$, por configurarse uma razão entre a produção agregada e o consumo agregado.

A utilização de um conjunto de pesos para cada $D M U$ resulta em uma medida de desempenho específica para cada escola sob avaliação.

Os pesos para cada $D M U_{0}$ são determinados maximizando-se o valor da produtividade $E_{0}$, sujeito à restrição de que a produtividade de nenhuma $D M U$, calculada com os pesos da $D M U_{0}$, possa exceder um valor constante pré-fixado (usualmente tomado igual a 1). O seguinte problema de programação matemática pode ser usado para calcular tais pesos:

$$
\begin{gathered}
E_{0}=\max \quad \frac{\sum_{j=1}^{M} q_{j} y_{o j}}{\sum_{i=1}^{N} p_{i} x_{0 i}} \\
s / a \quad E_{k}=\quad \frac{\sum_{j=1}^{M} q_{j} y_{k j}}{\sum_{i=1}^{N} p_{i} x_{k i}} \leq 1 \quad \forall k=1,2, \ldots, K \\
p_{i} \geq 0, \quad \forall i=1,2, \ldots, N ; \quad q_{j} \geq 0, \quad \forall j=1,2, \ldots, M
\end{gathered}
$$

A medida $E_{0}$, produtividade da $D M U_{0}$, pode ser dividida pela produtividade máxima, constituindo-se, assim, numa medida da eficiência relativa da $D M U_{0}$, já que a produtividade máxima observada será sempre igual a 1.

Na solução desse problema de otimização, a eficiência da $D M U_{0}$ é maximizada sob a condição que a eficiência de cada uma das unidades não excede o valor 1 . Assim, uma $D M U_{k}$ será considerada eficiente, sob o ponto de vista da $D M U_{0}$, quando sua medida de eficiência relativa $E_{k}$ (calculada com os pesos da $D M U_{0}$ ) for igual a 1 , e ineficiente quando esta medida for menor que 1.

Na equação (1), o modelo definido caracteriza-se por um problema de programação fracional que pode ser reduzido a dois problemas de programação linear, empregando o procedimento de transformação de problemas fracionais de Charnes e Cooper, de acordo com [6] e [3]. Essa transformação se faz alterando a função objetivo 
em (1) e resulta em dois problemas de programação linear: Um que mantém constante o agregado de recursos e busca maximizar o agregado de produção (2); e, outro, que minimiza o agregado de recursos, mantendo constante o agregado de produção (3). Esses problemas estão explicitados na Figura 1.1.

Os problemas (2) e (3) são chamados problemas dos multiplicadores, por expressarem as taxas de substituição entre recursos e entre resultados (os pesos) - que definem a faceta da fronteira de eficiência na qual é projetada a $D M U_{0}$. O conceito de desempenho que está sendo mensurado em cada um deles torna-se mais claro quando se analisam problemas equivalentes a (2) e (3). Os problemas (4) e (5) da Figura 1.2 correspondem aos problemas duais dos problemas (2) e (3), respectivamente, e são conhecidos como problemas do envelopamento.

\begin{tabular}{|l|l|}
\hline $\begin{array}{l}\text { DEA orientado para o consumo } \\
\text { (problema dos multiplicadores) }\end{array}(2)$ & $\begin{array}{l}\text { DEA orientado para a produção } \\
\text { (problema dos multiplicadores) (3) }\end{array}$ \\
\hline $\max _{p_{i}, q_{j}} \sum_{j=1}^{M} y_{0 j} q_{j}$ & $\min _{p_{i}, q_{j}} \sum_{i=1}^{N} x_{0 i} p_{i}$ \\
$\mathrm{~s} / \mathrm{a}$ & $\mathrm{s} / \mathrm{a}$ \\
$\sum_{i=1}^{N} x_{0 i} p_{i}=1$ & $\sum_{j=1}^{M} y_{0 j} q_{j}=1$ \\
$\sum_{i=1}^{N} x_{k i} p_{i}-\sum_{j=1}^{M} y_{k j} q_{j} \geq 0$, & $\sum_{i=1}^{N} x_{k i} p_{i}-\sum_{j=1}^{M} y_{k j} q_{j} \geq 0$, \\
$\forall k=1,2, \ldots, K$, & $\forall k=1,2, \ldots, K$ \\
$p_{i} \geq 0, \forall i=1,2, \ldots, N$ & $p_{i} \geq 0, \forall i=1,2, \ldots, N$ \\
$q_{j} \geq 0, \forall j=1,2, \ldots, M$ & $q_{j} \geq 0, \forall j=1,2, \ldots, M$ \\
\hline
\end{tabular}

Figura 1.1: DEA - problemas dos multiplicadores.

\begin{tabular}{|c|c|}
\hline $\begin{array}{l}\text { DEA orientado para o consumo } \\
\text { (problema do envelopamento) (4) }\end{array}$ & $\begin{array}{l}\text { DEA orientado para a produção } \\
\text { (problema do envelopamento) (5) }\end{array}$ \\
\hline $\begin{array}{l}\min \theta \\
\quad \mathrm{s} / \mathrm{a} \\
\sum_{k=1}^{K} z_{k} y_{k j} \geq y_{0 j}, \forall j=1,2, \ldots, M \\
x_{0 i} \theta-\sum_{k=1}^{K} z_{k} x_{k i} \geq 0, \forall i=1,2, \ldots, N \\
\theta \in \mathbb{R} ; z_{k} \geq 0 \forall k=1,2, \ldots, K\end{array}$ & $\begin{array}{l}\max \lambda \\
\quad \mathrm{s} / \mathrm{a} \\
y_{0 j} \lambda-\sum_{k=1}^{K} z_{k} y_{k j} \leq 0, \forall j=1,2, \ldots, M \\
\sum_{k=1}^{K} z_{k} x_{k i} \leq x_{0 i}, \forall i=1,2, \ldots, N \\
\lambda \in \mathbb{R}, z_{k} \geq 0, \forall k=1,2, \ldots, K\end{array}$ \\
\hline
\end{tabular}

Figura 1.2: DEA - problemas do envelopamento.

As regiões de viabilidade dos problemas (4) e (5) caracterizam, respectivamente, o conjunto de necessidades de consumo $(L)$ associado ao vetor de produção da $D M U_{0}\left(L\left(y_{0}\right)\right)$ e o conjunto de possibilidades de produção $(P)$ associado ao seu vetor de consumo $P\left(x_{0}\right)$. Os escalares $Z_{k}$ são os coeficientes dos planos de produção $\left(x_{k}, y_{k}\right)$, nas combinações lineares que definem a tecnologia de produção.

O valor ótimo para $\theta$ no problema (4), que notaremos $\theta^{*}$, representa a contração equiproporcional máxima possível no vetor de recursos da $D M U_{0}$, mantendo-se constante o vetor de observados. Se nenhuma contração equiproporcional for possível, 
então $\theta^{*}=1$ e a $D M U_{0}$ é dita eficiente na isoquanta do conjunto de necessidades de consumo $L\left(y_{0}\right)$. Se $\theta^{*}<1$, então a $D M U_{0}$ é ineficiente e $\theta^{*}$ é a medida de sua ineficiência, já que os recursos utilizados poderiam ser reduzidos equiproporcionalmente de $x_{0}$ para $\theta^{*} x_{0}$ sem redução nos resultados produzidos.

De maneira equivalente, $\lambda^{*}$, o valor ótimo do problema (5), é a expansão máxima possível no vetor de resultados da $D M U_{0}$, mantendo-se constante o vetor de recursos utilizados. Se $\lambda^{*}=1$, então nenhuma expansão é possível e a $D M U_{0}$ é dita eficiente na isoquanta do conjunto de possibilidades de produção $P\left(x_{0}\right)$. Se $\lambda^{*}>1$, então a $D M U_{0}$ é dita ineficiente e seus resultados podem ser expandidos de $y_{0}$ para $\lambda^{*} y_{0}$ sem acréscimo de recursos. O valor $1 / \lambda^{*}$ define a medida de eficiência fraca da $D M U_{0}$ orientada para o aumento da produção de resultados.

As medidas radiais (proporcionais) de eficiência estão ilustradas na Figura 1.3. que mostra as orientações para a maximização da produção e para a minimização do consumo e as projeções radiais (equiproporcionais) para as fronteiras.

As medidas definidas nos problemas (4) e (5) se caracterizam por uma projeção radial (equiproporcional) sobre a fronteira, mantendo, portanto, as proporções entre recursos e entre resultados observadas na $D M U_{0}$.

As medidas radiais (equiproporcionais) têm a vantagem de serem independentes de unidades de medidas e, portanto, independentes de relações de preços. Por outro lado, a contração equiproporcional de todos os recursos, ou expansão equiproporcional de todos os resultados, sugere eficiência mesmo quando permanecem excessos no consumo de algum recurso ou folga (falta) na produção de algum resultado.
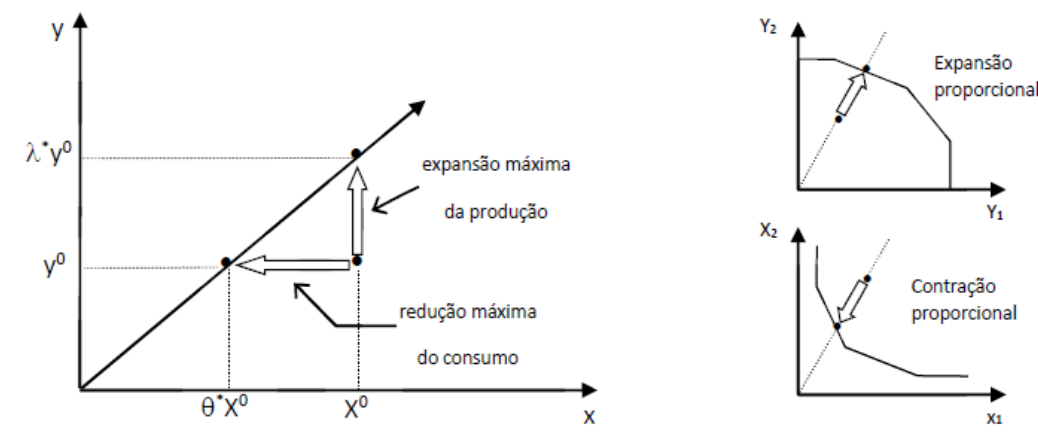

Figura 1.3: DEA - Medidas radiais de eficiência produtiva.

\subsubsection{Modelo CCR}

É sempre possível trabalhar, separadamente, com a medida de eficiência radial e os possíveis excessos no consumo de recursos e folgas na produção. Charnes, Cooper e Rhodes [5], propõem um modelo de avaliação da eficiência que calcula, 
simultaneamente, as folgas e os excessos existentes, mesmo mantendo o princípio da projeção radial sobre a fronteira (Modelo CCR). A Figura 1.4 (orientado para o consumo de recursos) e Figura 1.5 (orientado para a produção de resultados) representam os problemas de programação linear associados ao modelo CCR.

Apesar do cálculo em paralelo da expansão proporcional e dos excessos e folgas, o procedimento de otimização proposto pode ser interpretado em duas etapas consequentes:

1. um deslocamento radial na direção da fronteira e;

2. um movimento não-radial para a fronteira de eficiência.

\begin{tabular}{|l|l|}
\hline \multicolumn{2}{|c|}{$\begin{array}{c}\text { Modelo CCR orientado para o consumo retornos constantes à escala } \\
\text { - descarte forte de recursos e resultados }\end{array}$} \\
\hline $\begin{array}{l}\text { (problema dos multiplicadores) } \\
\max _{p_{i}, q_{j}} \sum_{j=1}^{M} y_{0 j} q_{j}\end{array}$ & $\begin{array}{l}\text { (problema do envelopamento) } \\
\mathrm{s} / \mathrm{a}\end{array}$ \\
$\min \theta-\varepsilon\left(\sum_{j=1}^{M} s_{j}^{+}+\sum_{i=1}^{N} s_{i}^{-}\right)$ \\
$\sum_{i=1}^{N} x_{0 i} p_{i}=1$ & $\mathrm{~s} / \mathrm{a}$ \\
$\sum_{i=1}^{N} x_{k i} p_{i}-\sum_{j=1}^{M} y_{k j} q_{j} \geq 0$, & $\sum_{k=1}^{K} z_{k} y_{k j}-s_{j}^{+}=y_{0 j}, \forall j=1,2, \ldots, M$ \\
$\forall k=1,2, \ldots, K$ & $\theta \in \mathbb{R} ; z_{0 i} \theta-\sum_{k=1}^{K} z_{k} x_{k i}-s_{i}^{-}=0, \forall i=1,2, \ldots, N$ \\
$p_{i} \geq \varepsilon, \forall i=1,2, \ldots, N$ & $s_{j}^{+} \geq 0, \forall j=1,2, \ldots, M ; s_{i}^{-} \geq 0$, \\
$q_{j} \geq \varepsilon, \forall j=1,2, \ldots, M$ & $\forall i=1,2, \ldots, N$ \\
$\varepsilon>0, \varepsilon \in \mathbb{R}$ & \\
\hline
\end{tabular}

Figura 1.4: DEA - Modelo CCR orientado para consumo.

\begin{tabular}{|c|c|}
\hline \multicolumn{2}{|c|}{$\begin{array}{c}\text { Modelo CCR orientado para a produção retornos constantes à escala } \\
\text { - descarte forte de recursos e resultados }\end{array}$} \\
\hline (problema dos multiplicadores) & (nrobloma do onvolonamento) \\
\hline $\min _{p_{i}, q_{j}} \sum_{i=}^{N}$ & $\max \lambda+\varepsilon\left(\sum_{j=1}^{M} s_{j}^{+}+\sum_{i=1}^{N} s_{i}^{-}\right)$ \\
\hline $\mathrm{s} / \mathrm{a}$ & $\mathrm{s} / \mathrm{a}$ \\
\hline$\sum_{j=1}^{M} y_{0 j} q_{j}=1$ & $y_{0 j} \lambda-\sum_{k=1}^{K} z_{k} y_{k j}+s_{j}^{+}=0, \forall j=1,2 . ., M$ \\
\hline $\begin{array}{c}\sum_{i=1}^{N} x_{k i} p_{i}-\sum_{j=1}^{M} y_{k j} q_{j} \geq 0 \\
\forall k=1,2, \ldots, K \\
p_{i} \geq \varepsilon, \forall i=1,2, \ldots, N\end{array}$ & $\sum_{k=1}^{K} z_{k} x_{k i}+s_{i}^{-}=x_{0 i}, \forall i=1,2, \ldots, N$ \\
\hline $\begin{array}{l}q_{j} \geq \varepsilon, \forall j=1,2, \ldots, M \\
\varepsilon>0, \varepsilon \in \mathbb{R}\end{array}$ & $\lambda \in \mathbb{R} ; z_{k} \geq$ \\
\hline & \\
\hline
\end{tabular}

Figura 1.5: DEA - Modelo CCR orientado para a produção.

Dessa forma, a projeção de uma $D M U$ ineficiente sobre a fronteira é feita em duas etapas conforme a Figura 1.6. 
As expressões $\sum_{k=1}^{K} z_{k} y_{k j}$ e $\sum_{k=1}^{K} z_{k} x_{k i}$ nas restrições dos problemas do envelopamento representam combinações lineares dos resultados e dos recursos das $K$ $D M U^{\prime} s$ tomadas como referências e o escalar $Z_{k}$ é o coeficiente da $D M U_{k}$ nessas combinações. A falta de restrições sobre os valores dos $Z_{k}$ pressupõe a hipótese de retornos constantes à escala de produção, uma vez que quaisquer expansões ou contrações dos planos de produção observados sejam viáveis. As desigualdades presentes nas duas primeiras restrições desses problemas caracterizam o livre descarte de recursos e resultados. Seguem esquemas de projeção para a fronteira.

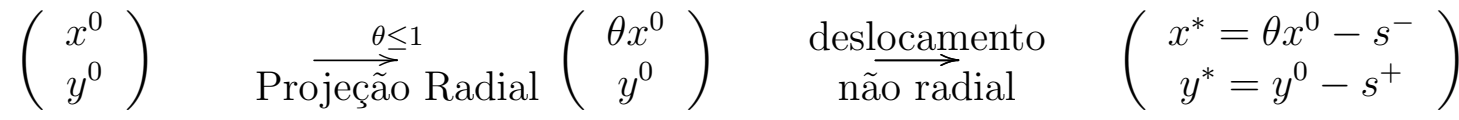

$$
\begin{aligned}
& \text { a) modelo orientado para o consumo }
\end{aligned}
$$

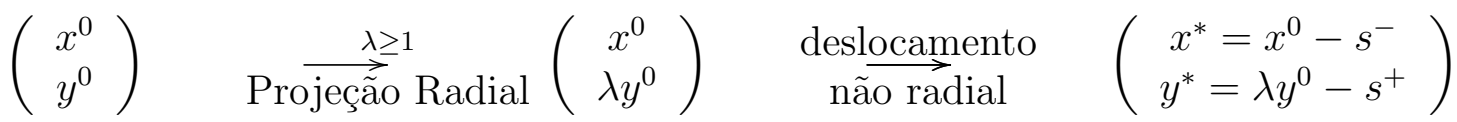

$$
\begin{aligned}
& \text { b) modelo orientado para a produção }
\end{aligned}
$$

Figura 1.6: DEA - Etapas da projeção para a fronteira.

\subsubsection{Modelo BCC}

Em 1984, Banker, Charnes e Cooper desenvolveram um modelo DEA conhecido como Modelo BCC, [2], que pressupõe tecnologias que exibam retornos variáveis à escala de produção e descarte forte de recursos e resultados. Esse modelo admite que a produtividade máxima varie em função da escala de produção, ao possibilitar que a tecnologia exiba propriedades de retornos às escalas diferentes ao longo de sua fronteira.

A medida de eficiência resultante permite que se isole da ineficiência produtiva total o componente associado à escala de produção, permitindo identificar a ineficiência técnica. O modelo possibilita a utilização de unidades de referência de portes distintos viabilizando assim o uso de todas as escolas como unidades de referência, independentemente do tamanho, pois estas estão livres das dificuldades que surgem ao considerar a escala de produção.

Os problemas de programação linear associados ao Modelo BCC estão representados na Figura 1.7, na qual estão assinaladas as diferenças em relação ao Modelo CCR. 


\begin{tabular}{|l|l|}
\hline \multicolumn{2}{|c|}{ Modelo BCC orientado para a produção retornos variáveis à escala } \\
- descarte forte de recursos e resultados
\end{tabular}

Figura 1.7: DEA - Modelo BCC orientado para a produção.

O problema do envelopamento do Modelo BCC se diferencia do seu equivalente no Modelo CCR pela restrição $\sum_{k=1}^{K} z_{k}=1$, que restringe as combinações lineares dos planos observados a combinações convexas desses planos. A tecnologia restringe-se a contrações dos planos de produção observados, impedindo expansões e, assim, caracterizando a hipótese de retornos variáveis à escala.

O hiperplano suporte ao conjunto tecnologia definido por $\left(\mathrm{p}^{*}, \mathrm{q}^{*}\right)$, no problema dos multiplicadores, tem um termo independente de variável $\left(v_{0}\right)$ que exerce o papel de intercepto, possibilitando a existência na fronteira de facetas definidas por hiperplanos que não passam na origem, o que caracteriza, de forma equivalente ao problema do envelopamento, retornos variáveis à escala.

\subsubsection{DEA e a Análise de Dados}

Considerando qualquer um dos modelos citados de DEA, cada escola será avaliada sob a visão que mais lhe convêm (os pesos relativos que maximizam sua produtividade) e só será considerada ineficiente se outra(s) escola(s) obtiver(em), com a estrutura de pesos escolhida, uma produtividade maior. Desta forma, para cada escola avaliada, se estabelece uma ordenação de todas elas, segundo as eficiências calculadas com os pesos relativos adotados (resultantes do processo de otimização).

O modelo DEA empregado para cada escola ineficiente identifica um conjunto de escolas eficientes que formam um grupo de referência (benchmarks) para a análise do desempenho da escola em avaliação. Essas escolas de referência determinam uma faceta no conjunto de possibilidades de produção na qual será projetado (Figura 1.6 .

O vetor de resultados $y_{0}$ é expandido radialmente para $\lambda^{*} y_{0}$, mantido o vetor de recursos $x_{0}$, determinando uma meta (meta proporcional) para a produção, e isso 
constitui a primeira etapa. Um novo conjunto de relações parciais de produtividade é determinado e este explicita as relações entre recursos e resultados que podem ser alcançadas sem alteração nas quantidades de recursos consumidos.

Numa segunda etapa serão tratadas as possíveis folgas na produção e excessos no consumo observados após a expansão proporcional. A eliminação das folgas e excessos é proposta a partir de um conjunto de pesos (taxas de substituição) fornecido pelo problema dos multiplicadores, obtendo-se uma meta global para cada escola ineficiente.

Conhecendo a medida de eficiência, a análise dos resultados da aplicação do modelo DEA se concentra no estudo da faceta de eficiência associada a cada escola avaliada. As características da faceta de eficiência permitem estudar o sentido da medida obtida e a viabilidade das metas projetadas para cada escola.

A medida de eficiência relativa de cada escola calculada pelos modelos DEA corresponde à distância entre o plano de operação realizado e a fronteira eficiente. A fronteira é composta de seções lineares - chamadas facetas de eficiência - determinadas pelas combinações convexas de subconjuntos de escolas eficientes. Cada escola corresponde a uma faceta de eficiência em relação à qual sua medida de eficiência é calculada e na qual sua meta global é projetada.

As facetas de eficiência são caracterizadas por um conjunto de vértices e um conjunto de taxas de substituição entre variáveis. Os vértices definem os limites de cada faceta, enquanto as taxas de substituição refletem relações de valor entre as variáveis e descrevem as condições de equilíbrio (otimalidade) que garantem a condição de eficiência.

Os vértices da faceta de eficiência são as escolas eficientes de referência para a escola avaliada. A meta projetada para cada escola ineficiente é uma combinação convexa dos planos de operação de suas escolas de referência. As referências caracterizam-se como planos de operação similares a cada escola a ser avaliada.

As taxas de substituição estão expressas nas variáveis duais e representam produtividades marginais que consistem em ponderadores utilizados na agregação dos recursos e dos resultados. Essas taxas definem as funções de produção que determinam a fronteira de eficiência. Para cada escola avaliada, as taxas de substituição descrevem as relações de produção associadas à sua faceta na fronteira de possibilidades de produção, definindo a função de produção naquela seção linear da fronteira.

$\mathrm{Na}$ avaliação do desempenho de uma escola, na qual não existem preços relativos entre recursos e entre resultados, as taxas de substituição devem ser interpretadas como indicadores da importância relativa dos recursos e dos resultados na caracterização do plano de operação eficiente adotado como meta global.

Para avaliar a importância de cada escola eficiente na determinação das facetas é necessário identificar o número de vezes que cada uma delas aparece como 
referência para as ineficientes.

\subsubsection{Seleção de Variáveis em DEA}

Para a seleção de variáveis na análise de dados usaremos o procedimento de seleção de Norman e Stoker.

Em [11], Norman e Stoker propuseram um procedimento de seleção de variáveis para a construção de funções de desempenho que utiliza uma combinação de análise de correlações lineares simples e DEA.

A aplicação da técnica DEA pressupõe uma classificação prévia das variáveis em recursos ou resultados para a construção da função de desempenho. Uma análise estatística dos dados deve identificar as relações existentes entre as variáveis e entre conjuntos de variáveis, condição necessária para classificá-las como descritoras dos recursos ou dos resultados do processo produtivo. As medidas de associação estatística entre recursos e resultados devem refletir relações causais adequadas, identificando, em particular, que recursos são responsáveis por cada resultado e que resultados são esperados de cada recurso.

Devem, também, serem analisadas as associações entre recursos e entre resultados para identificar se existe complementaridade ou competição entre eles. Assim, não deve haver independência estatística entre duas variáveis descritoras dos resultados ou dos recursos, isto é, a associação entre duas variáveis representativas dos recursos ou ambas representativas dos resultados deve ser positiva (caracterizando atividades complementares) ou negativa (atividades concorrentes ou competitivas), mas não deve ser muito próxima de zero.

Conhecida a classificação das variáveis em recursos ou resultados, utiliza-se o procedimento de seleção de variáveis proposto por Norman e Stoker para identificar aquelas que mais influenciam o desempenho de uma escola e construir um indicador único da eficiência produtiva que considera esses fatores conjuntamente. Esse procedimento identifica os recursos e os resultados mais relevantes à mensuração do desempenho adotado através da construção de uma sequência de funções de desempenho.

A função de desempenho da primeira etapa do procedimento de Norman e Stoker corresponde a um único resultado e um único recurso. Em cada uma das etapas seguintes são observadas as associações entre cada variável e o indicador da eficiência da etapa anterior para decidir se existem novas variáveis a considerar na função de desempenho. Essas novas variáveis podem representar um novo recurso ou um novo resultado, bem como decomposições de variáveis já presentes no modelo.

Se alguma variável que influência a eficiência estiver ausente da função de desempenho, então o indicador da eficiência calculado deverá estar viesado com relação ao fator educacional descrito por esta variável. Deve-se esperar, nesse caso, associação 
estatística significativa entre o indicador da eficiência e essa variável, que é indicativa da possibilidade de entrada dessa variável na função de desempenho. A recíproca não é, necessariamente, verdadeira. Associações estatísticas fortes não permitem concluir que uma dada variável influencia o desempenho. É necessário determinar relações causais lógicas entre cada fator e a eficiência produtiva.

A relevância da decomposição de variáveis que estão presentes de forma agregada na função de desempenho é verificada através da análise das correlações entre as suas parcelas e o indicador da eficiência. Associações inversas entre parcelas e a eficiência são sinalizadoras da necessidade de decomposição da variável agregada. Na Figura 1.8 apresentamos um fluxograma do procedimento citado.

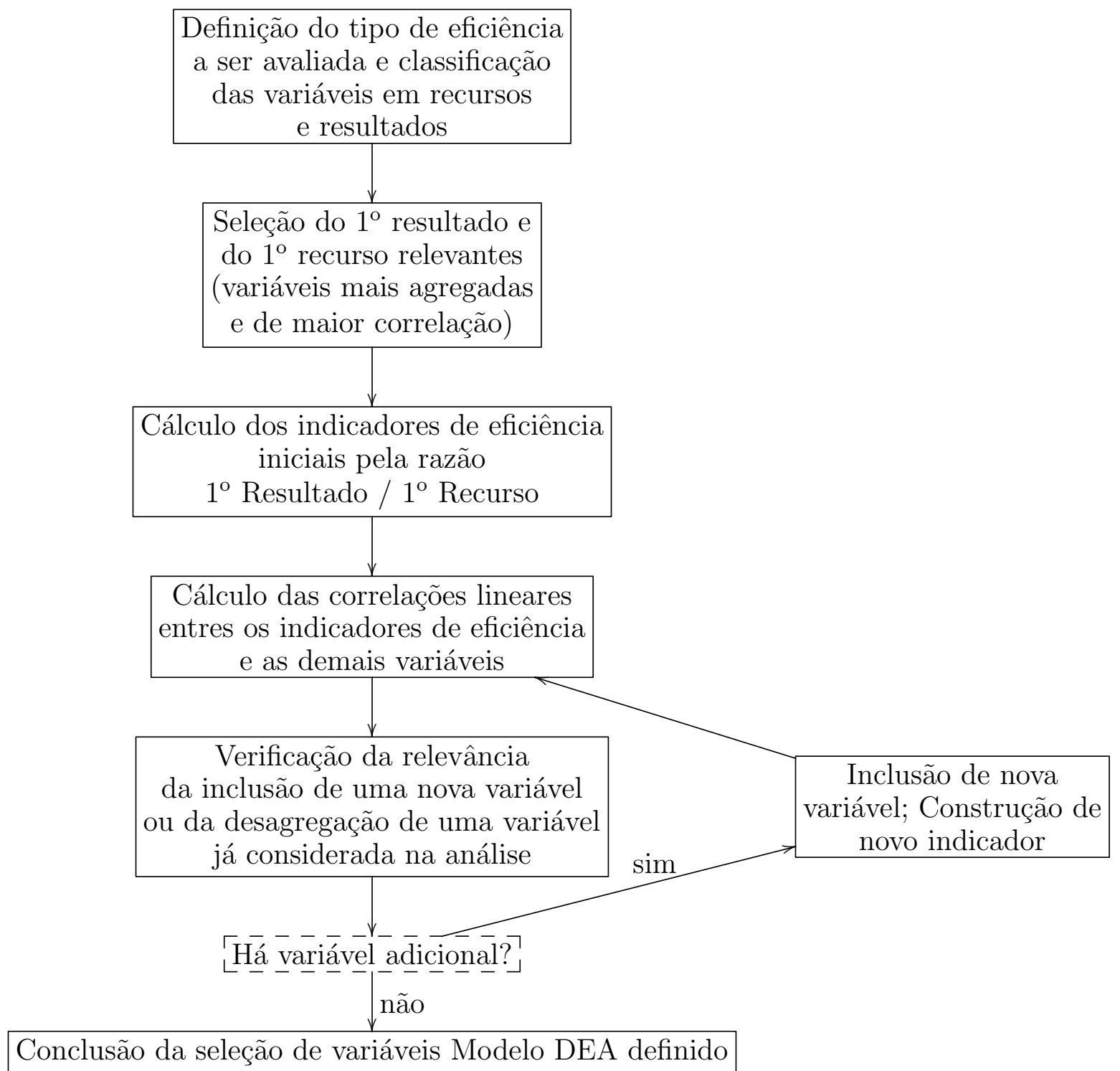

Figura 1.8: Fluxograma descritivo do procedimento de Norman e Stoker. 


\subsection{Análise de Conglomerados}

A análise de conglomerados consiste em um processo de partição de uma população heterogênea em vários subgrupos mais homogêneos. Seu objetivo é buscar entender a estrutura dos dados aglomerando observações similares em grupos. No agrupamento, não há classes pré-definidas, os elementos são agrupados de acordo com a similaridade entre eles. Os grupos são determinados de forma a obter-se homogeneidade dentro dos grupos e heterogeneidade entre eles.

A sua aplicação é, portanto, bastante imediata e pode conferir um bom poder explanatório à pesquisa, supondo que decisões ponderadas sejam tomadas sobre formas alternativas para mensuração de similaridades, critérios para formação de grupos e número ideal de grupos a serem formados.

Uma análise de conglomerados mais criteriosa deve apresentar métodos com as seguintes características:

- Ser capaz de lidar com dados com alta dimensionalidade;

- Ser "escalável" com o número de dimensões e com a quantidade de elementos a serem agrupados;

- Habilidade para lidar com diferentes tipos de dados;

- Capacidade de definir agrupamentos de diferentes tamanhos e formas;

- Ser robusto à presença de ruído;

- Apresentar resultado consistente independente da ordem em que os dados são apresentados.

Existem várias técnicas de análise de conglomerados, as quais permitem diferentes medidas de similaridade e métodos de formação de grupos. As medidas de similaridades entre os elementos a serem agrupados normalmente são expressas como uma função distância ou métrica.

Seja $M$ um conjunto de dados. Aplicando-se uma métrica em $M$ tem-se uma função $d: M \times M \rightarrow \mathbb{R}$, tal que para qualquer observação $A, B, C \in M$ a métrica deve satisfazer:

1. $\mathrm{d}(\mathrm{A}, \mathrm{B})>0$, para todo $\mathrm{A} \neq \mathrm{B}$

2. $d(A, A)=0$

3. $\mathrm{d}(\mathrm{A}, \mathrm{B})=\mathrm{d}(\mathrm{B}, \mathrm{A})$

4. $\mathrm{d}(\mathrm{A}, \mathrm{B}) \leq \mathrm{d}(\mathrm{A}, \mathrm{C})+\mathrm{d}(\mathrm{C}, \mathrm{B})$

Serão apresentadas, a seguir, algumas medidas que calculam as similaridades, que são as distâncias entre os elementos. Essa distância é normalmente representada na forma de matriz, ou seja, em uma matriz de similaridade. Esta matriz de similaridade é simétrica.

A distância euclidiana é a distância geométrica no espaço multidimensional. A distância euclidiana entre dois elementos $X=\left[X_{1}, X_{2}, \ldots, X_{p}\right]$ e 
$Y=\left[Y_{1}, Y_{2}, \ldots, Y_{p}\right]$ elementos de $\mathbb{R}^{p}$ é dada por:

$$
d_{X Y}=\sqrt{\left(X_{1}-Y_{1}\right)^{2}+\left(X_{2}-Y_{2}\right)^{2}+\ldots+\left(X_{p}-Y_{p}\right)^{2}}=\sqrt{\sum_{i}^{p}\left(X_{i}-Y_{i}\right)^{2}}
$$

A distância Manhattan é definida pela expressão:

$$
d M_{X Y}=\sqrt{\left|X_{1}-Y_{1}\right|+\left|X_{2}-Y_{2}\right|+\ldots+\left|X_{p}-Y_{p}\right|}=\sqrt{\sum_{i}^{p}\left|X_{i}-Y_{i}\right|}
$$

Em alguns casos os resultados apresentados pela distância de Manhattan são próximos aos da distância Euclidiana. No caso da distância de Manhattan como as diferenças não são elevadas ao quadrado o efeito das dimensões elevadas de algum elementos é maximizado.

A distância de Chebychev é apropriada no caso em que se deseja definir dois elementos como diferentes, se apenas uma das dimensões é diferente. Ela é definida por:

$$
d C_{X Y}=\max \left\{\left|X_{1}-Y_{1}\right|,\left|X_{2}-Y_{2}\right|, \cdots,\left|X_{p}-Y_{p}\right|\right\}
$$

Existem várias técnicas que são utilizadas para formar os grupos de conglomerados, ou seja, são técnicas que auxiliam na formação dos conglomerados.

As Técnicas Hierárquicas Aglomerativas consideram cada indivíduo (observação) como um conglomerado de tamanho 1, ou seja, inicialmente têm-se $n$ conglomerados. Os pares de conglomerados mais similares são agrupados e passam a constituir um único conglomerado.

Os métodos aglomerativos são caracterizados de acordo com o critério utilizado para medir a distância entre os grupos. Eis alguns deles:

1. Métodos de ligação:

(a) Single linkage (ou ligação por vizinho mais próximo);

(b) Complete linkage(ou ligação por vizinho mais distante);

(c) Average linkage(ou ligação por média);

(d) Median linkage(ou ligação por mediana);

2. Métodos de centróide (ou ligação por centróide);

3. Métodos de soma de erros quadráticos ou variância (método de Ward). 
Os grupos, nos métodos hierárquicos, são geralmente representados por um diagrama bi-dimensional chamado de dendograma ou diagrama de árvore conforme Figuras 3.15 e 3.20. Nestes diagramas, cada ramo representa um elemento, enquanto a raiz representa o agrupamento de todos os elementos. Através do dendograma e do conhecimento prévio sobre a estrutura dos dados, deve-se determinar uma distância de corte para definir quais serão os grupos formados.

Essa decisão é subjetiva e deve ser feita de acordo com o objetivo da análise e o número de grupos desejados. Se eles apresentam resultados semelhantes, significa que o grupo está bem definido no espaço, ou seja, o grupo é real. Mas se ocorre o contrário, os grupos provavelmente não existem, conforme [14].

As Técnicas Hierárquicas Divisivas trabalham na direção oposta dos métodos aglomerativos, ou seja, um grupo inicial contendo todos os elementos é dividido em dois subgrupos, de tal forma que os elementos em um subgrupo estejam distantes dos elementos do outro subgrupo. Esses subgrupos são então divididos em subgrupos dissimilares e o processo continua até cada elemento formar um grupo. O método divisivo exige um maior número de iterações (que cresce exponencialmente), pois começa considerando todas as divisões dos elementos em dois grupos, com pelo menos um elemento em cada grupo.

Os métodos não-hierárquicos, ou por particionamento, foram desenvolvidos para agrupar elementos em $K$ grupos, onde $K$ é a quantidade de grupos definida previamente. Nem todos valores de $K$ apresentam grupos satisfatórios, sendo assim, aplica-se o método várias vezes para diferentes valores de $K$, escolhendo os resultados que apresentem melhor interpretação dos grupos ou uma melhor representação gráfica. Na referência 44 o leitor encontra mais detalhes.

A ideia central da maioria dos métodos por particionamento é escolher uma partição inicial dos elementos e, em seguida, alterar os membros dos grupos para obterse a melhor partição, segundo [1].

Quando comparado com o método hierárquico, o método por particionamento é mais rápido porque não é necessário calcular e armazenar, durante o processamento, a matriz de similaridade.

Em geral, os métodos por particionamento diferem entre si pela maneira que constituem a melhor partição. Os métodos por particionamento mais conhecidos são o método k-means (k-médias) e o método $k$-medoid (k-medóides).

\subsection{Análise de Componentes Principais}

A Análise de Componentes Principais (ACP) permite estudar a estrutura das variáveis na matriz $\mathrm{X}$ sem a necessidade de conhecer suas distribuições de proba- 
bilidade. As variáveis nesse caso devem ser quantitativas.

O objetivo da ACP é transformar as variáveis originais, que constituem um espaço p-dimensional, em novas variáveis ortogonais que constituem um espaço $\mathrm{r}$-dimensional $(\mathrm{r} \leq \mathrm{p})$. As componentes devem explicar a maior quantidade possível da variabilidade do sistema.

Para o cálculo da componente principal é preciso conhecer a variância das variáveis. A variância de um vetor X é uma matriz $\Sigma$. O objetivo é traduzir esta matriz a um só número. A variância total é a soma das variâncias dos elementos que estão representados na diagonal principal da matriz $\Sigma$, é o chamado traço da matriz:

$$
\text { variância total }=\sum_{i=1}^{p} \sigma_{i}^{2}=\operatorname{tr}(\Sigma)=\sum_{i=1}^{p} \operatorname{var}\left(x_{i}\right)
$$

onde,

$$
\operatorname{tr}(\Sigma)=\sum_{i=1}^{p} \lambda_{i}
$$

onde $\lambda_{i}$ são os autovalores da matriz $\Sigma$ ordenados em ordem decrescente $\left(\lambda_{i} \geq \ldots \geq \lambda_{p}\right)$.

Em ACP deve-se encontrar uma combinação linear das variáveis originais de modo que a variância desta combinação linear seja máxima em relação à variância total.

Uma componente principal é $Y=a_{i}^{T} x$, deve-se definir um vetor " $a$ " que maximize a variância de $\mathrm{Y}$, tem-se:

$$
\operatorname{var}(Y)=\operatorname{var}\left(a_{i}^{T} x\right)=a_{i}^{T} \cdot \operatorname{var}(x) \cdot a=a_{i}^{T} \cdot S \cdot a
$$

onde $S$ é uma matriz quadrada.

Utiliza-se a restrição: $a^{T} a=\sum_{i=1}^{p} a_{i}^{2}=1$ (norma unitária)

Calcula-se o máximo da variância usando os multiplicadores de Lagrange, derivando e igualando a zero. Tem-se:

$$
\begin{gathered}
\varphi=a^{T} S a-l\left(a^{T} a-1\right) \\
\frac{d \varphi}{d a}=\frac{d}{d a}\left[a^{T} S a-l\left(a^{T} a-1\right)\right]=0 \\
=2(S a-l a)=0 \\
=2(S-l \mathrm{I}) a=0 \\
=(S-l \mathrm{I}) a=0
\end{gathered}
$$

Resolvendo a equação anterior obtêm-se p-autovalores, um para cada componente principal. Os autovalores são as variâncias das componentes e a $1^{\mathrm{a}}$ componente é aquela que apresentar maior variância. A contribuição de cada componente na 
variância total pode ser calculada da seguinte forma:

$$
\frac{\operatorname{var}\left(Y_{i}\right)}{\operatorname{tr}(S)}=\frac{\lambda_{i}}{\sum_{i=1}^{p} \lambda_{i}}=\frac{\lambda_{i}}{\lambda_{1}+\lambda_{2}+\ldots+\lambda_{p}}
$$

Propriedades das Componentes Principais:

a) $E\left(Y_{i}\right)=0, \forall \mathrm{i} \in\{1,2,3, \cdots, p\}$

b) $\operatorname{Var}(Y)=\operatorname{diag}\left(\lambda_{1}, \lambda_{2}, \ldots, \lambda_{p}\right)$, onde $\operatorname{cov}\left(\mathrm{Y}_{i}, Y_{j}\right)=0, \mathrm{i} \neq \mathrm{j}, i, j \in\{1,2,3, \cdots, p\}$

c) $\operatorname{cov}\left(\mathrm{Y}_{i}, X_{j}\right)=\lambda_{i} a_{i j} ; \quad \operatorname{corr}\left(\mathrm{Y}_{i}, X_{j}\right)=\frac{\lambda_{i} a_{i j}}{S_{j} \sqrt{\lambda_{i}}}=\frac{a_{i j} \sqrt{\lambda_{i}}}{S_{j}}, i, j \in\{1,2,3, \cdots, p\}$

Indicamos a referência [8] ao leitor interessado em obter mais detalhes acerca de Análise de Componentes Principais.

\subsection{Coeficiente de Correlação de Pearson}

O Coeficiente de Correlação de Pearson (CCP) é uma medida do grau de relação linear entre duas variáveis quantitativas. Este coeficiente varia entre os valores -1 e 1. O valor 0 (zero) significa que não há relação linear, o valor 1 indica uma relação linear perfeita e o valor -1 também indica uma relação linear perfeita mas inversa, ou seja quando uma das variáveis aumenta a outra diminui. Quanto mais próximo estiver de 1 ou -1, mais forte é a associação linear entre as duas variáveis.

O Coeficiente de Correlação de Pearson é normalmente representado pela letra r e a sua fórmula de cálculo é:

$$
r=\frac{\sum_{i=1}^{p}\left(x_{i}-\bar{x}\right)\left(y_{i}-\bar{y}\right)}{\sqrt{\sum_{i=1}^{p}\left(x_{i}-\bar{x}\right)^{2} \sum_{i=1}^{p}\left(y_{i}-\bar{y}\right)^{2}}}
$$

$R=\left(r_{i j}\right), 1 \leq i, j \leq n, r_{i j}$ é a correlação entre as variáveis $x_{i}$ e $y_{j}$ dada por 1.1 , onde $R$ é matriz das correções $r_{i j}$. 


\section{Capítulo 2}

\section{Metodologia}

\subsection{Metodologia}

A trajetória metodológica desta pesquisa segue os seguintes passos:

1. Análise estatística exploratória dos dados com o objetivo de descrever a informação presente nas Bases de Dados, caracterizar as escolas e conhecer os fatores educacionais presentes nos dados. Esta análise utiliza Medidas Estatísticas, Análise de Componentes Principais, Análise de Correlação Linear Simples e Análise de Conglomerados. Desta análise obtém-se um conjunto pré-selecionado de variáveis e grupos de escolas para análise de desempenho.

2. A metodologia de avaliação do desempenho das escolas sob o ponto de vista da eficiência produtiva basea-se na Análise por Envoltória de Dados aplicada a subconjuntos de escolas classificadas a partir da infraestrutura disponível.

3. A aplicação de DEA permite a identificação das escolas de melhor desempenho e a determinação de ações e estratégias de melhoria para as escolas consideradas ineficientes.

Os passos apresentados permitiram alcançar os objetivos propostos. 


\section{Capítulo 3}

\section{Aplicação do Modelo DEA em Escolas Públicas do DF}

\subsection{Análise Exploratória dos Dados}

\section{Informações Disponíveis}

O Instituto Nacional de Estudos e Pesquisas Educacionais (INEP), é uma autarquia vinculada ao Ministério da Educação e tem como missão institucional produzir e disseminar informações educacionais. As estatísticas e avaliações produzidas pelo INEP visam fornecer os subsídios necessários para a formulação e implementação de políticas voltadas para a melhoria contínua da educação no País. Dentre as informações educacionais produzidas pelo INEP, destaca-se o Censo Escolar e os resultados da Prova Brasil.

Os dados da Secretaria de Educação - SE permitem determinar quais escolas pertencem a uma determinada Região Administrativa - RA e Coordenação Regional de Ensino - CRE, além de saber quais escolas são administradas pela SE.

\section{Dados}

Os dados utilizados foram os microdados da Prova Brasil, o Censo Escolar, a Taxa de Rendimento das Escolas, Taxa de Distorção Idade e Série e dados da Secretaria da Educação do Distrito Federal.

As escolas selecionadas para o estudo de DEA foram as Escolas Públicas do Distrito Federal. Foram desconsideradas as escolas federais como o Colégio Militar e o Dom Pedro II porque possuem características diferentes das outras escolas públicas. Os alunos que ingressam nessas escolas serão obrigados a fazer um Vestibulinho que é uma espécie de vestibular. Nas escolas públicas do Distrito Federal o aluno tem direito à vaga e, para se matricular, basta o responsável ligar para 156 ou ir à escola que 
almeja. Se a escola não tem vaga, o aluno é encaminhado para outra escola.

Pelo site do INEP tem-se que, no Distrito Federal, 88,5\% das escolas públicas são urbanas enquanto $11,5 \%$ são rurais como mostra a Tabela 3.1 .

Tabela 3.1: Número de Escolas da Rede Pública do DF por situação urbana e rural segundo CRE em 2013.

\begin{tabular}{l|c|c|c}
\hline \multirow{2}{*}{ CRE } & \multicolumn{3}{|c}{ Instituições Educacionais } \\
\cline { 2 - 4 } & Urbana & Rural & Total \\
\hline Plano Piloto - Cruzeiro & 103 & 0 & 103 \\
Gama & 43 & 7 & 50 \\
Taguatinga & 62 & 4 & 66 \\
Brazlândia & 18 & 12 & 30 \\
Sobradinho & 35 & 11 & 46 \\
Planaltina & 44 & 20 & 64 \\
Núcleo Bandeirante & 31 & 3 & 34 \\
Ceilândia & 89 & 0 & 89 \\
Guará & 25 & 0 & 25 \\
Samambaia & 40 & 0 & 40 \\
Santa Maria & 26 & 0 & 26 \\
Paranoá & 17 & 14 & 31 \\
São Sebastião & 19 & 4 & 23 \\
Recanto das Emas & 24 & 0 & 24 \\
\hline Total & 576 & 75 & 651 \\
\hline
\end{tabular}

Tabela 3.2: Número de Escolas no Ensino Fundamental por nível de ensino segundo a CRE em 2013.

\begin{tabular}{l|c|c}
\hline CRE & $1^{\circ}$ a $5^{\circ}$ ano & $6^{\circ}$ a $9^{\circ}$ ano \\
\hline Núcleo Bandeirante & 20 & 11 \\
Brazlândia & 15 & 8 \\
Ceilândia & 56 & 24 \\
Gama & 29 & 16 \\
Guara & 11 & 8 \\
Paranoá & 13 & 7 \\
Planaltina & 34 & 18 \\
Plano Piloto & 41 & 16 \\
Recanto das Emas & 16 & 11 \\
Samambaia & 22 & 12 \\
Santa Maria & 13 & 8 \\
São Sebatião & 12 & 5 \\
Sobradinho & 23 & 11 \\
Taguatinga & 33 & 13 \\
\hline Total & 338 & 168 \\
\hline
\end{tabular}

Tem-se 506 escolas de Ensino Fundamental, das quais 338 escolas oferecem 
Ensino Fundamental I ( $1^{\circ}$ ao $5^{\circ}$ ano) e 168 escolas o Ensino Fundamental II $\left(6^{\circ}\right.$ ao $9^{\circ}$ ano) como mostra a Tabela 3.2 .

Da base de dados da Prova Brasil, foram extraídas as notas em Português e Matemática dos anos de 2007, 2009, 2011 e 2013. Aparentemente, as notas de Matemática são maiores do que as de Português, porém, essas notas estão em escalas diferentes. No caso do Português começa com 125 e vai a 350, enquanto a Matemática começa com 125 e vai a 425 como mostram as Figuras 3.1 e 3.2 .

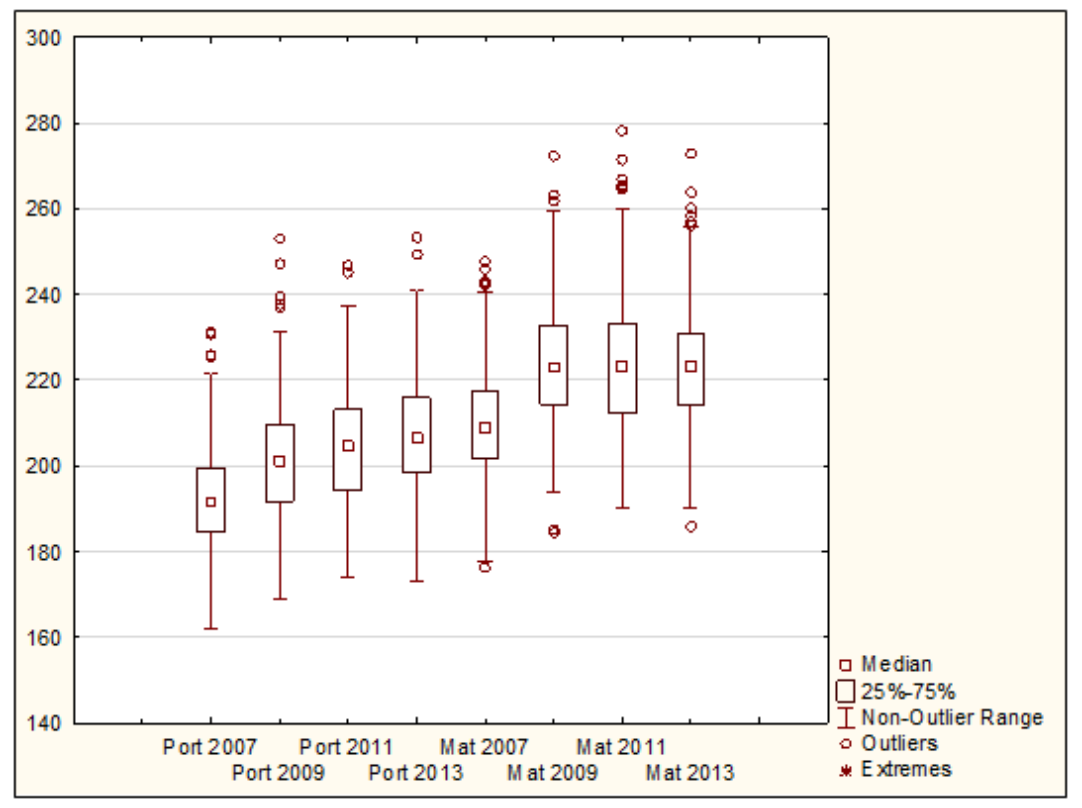

Figura 3.1: Nota da Prova Brasil do $5^{\circ}$ ano da Escola Pública do DF.

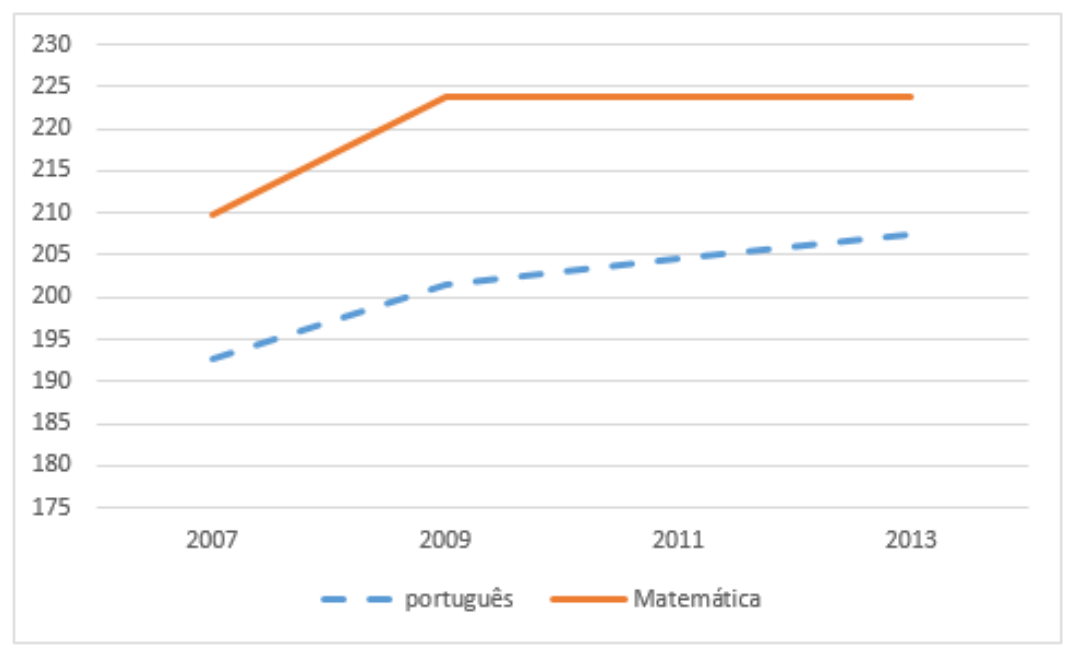

Figura 3.2: Média Ponderada da Prova Brasil do $5^{\circ}$ ano Escola Pública do DF. 
Observa-se que a média ponderada da Prova Brasil do $5^{\circ}$ ano na Figura 3.2 apresenta um aumento no período 2009 comparando com 2007 nas duas disciplinas. Porém, a média ponderada Matemática houve um decrescimento baixo de 2009 a 2013 , enquanto em Português houve um leve crescimento neste período. De acordo com a escala de desempenho do INEP, os alunos estão no nível 3 em Português e nível 5 em Matemática (informação mais detalhado no Apêndice Tabela A.1). Além disso, não podemos dizer que os alunos sabem mais Matemática do que Português porque as escalas são diferentes. No caso da Matemática a prova começa com escala 125 e o seu máximo é 425 enquanto Português começa com 125 e o máximo é 325. Em razão disso, do gráfico não é possível dizer se uma média é melhor do que a outra. Para viabilizar a comparação entre as notas fez-se uma padronização da seguinte forma:

$$
\text { Valor padronizado }=\frac{100 \cdot(\text { média ponderada-nota mínima })}{(\text { nota máxima-nota mínima })}
$$

Com isso, os valores passam a ser de 0 a 100 e pode-se comparar as médias Português e Matemática, conforme se observa na Figura 3.3 .

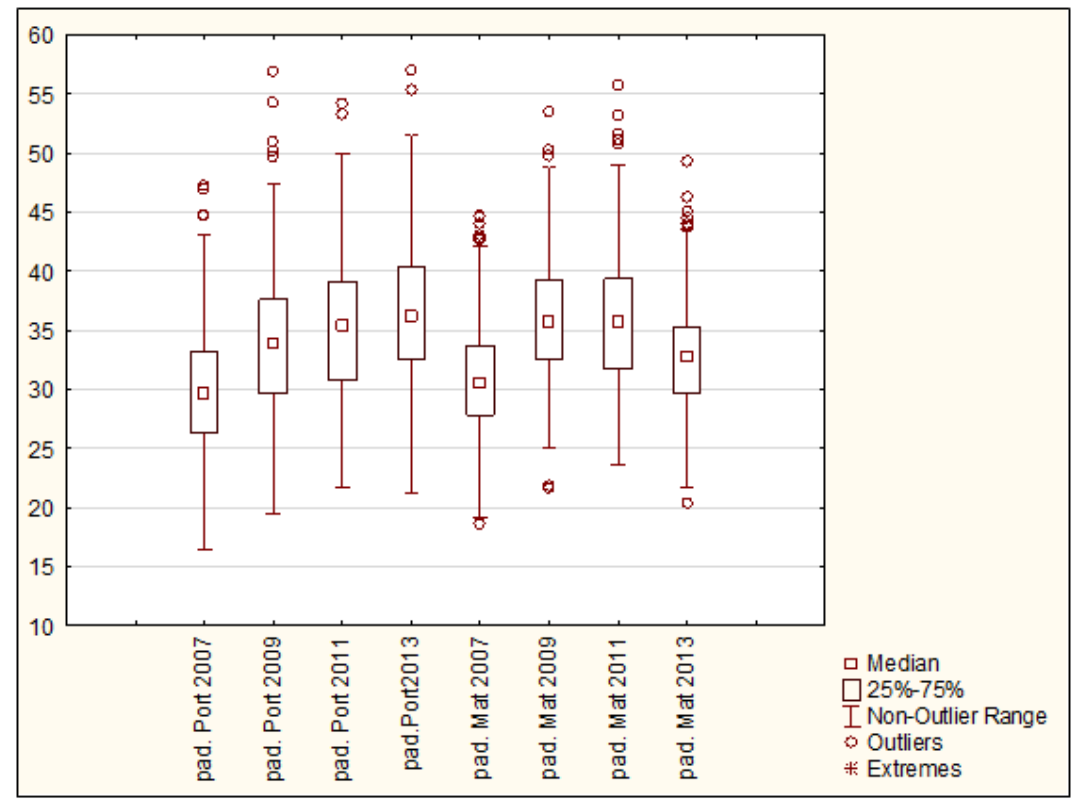

Figura 3.3: Padronização da Nota do $5^{\circ}$ ano da Prova Brasil da Escola Pública do DF.

Na Figura 3.3 observa-se que a nota da Prova Brasil do $5^{\circ}$ ano tem desempenhos próximos em Português e Matemática. Por outro lado, os alunos possuem médias inferiores a 40 e se utilizassem o critério das escolas públicas para a aprovação que é de 50, isso implicaria que a maioria dos alunos seriam reprovados.

A Taxa de Aprovação é outro indicador de qualidade e neste caso foram considerados apenas os anos em que foram aplicados a Prova Brasil. A Figura 3.4 
mostra que a maioria dos alunos são aprovados porque a mediana da taxa é superior a $90 \%$ nos anos considerados. Ou seja, a maioria dos alunos foram aprovados sem ter uma base sólida em Matemática e Português de acordo com a nota da Prova Brasil. Um dos motivos de isso ocorrer é que o regimento escolar pode aprovar o aluno mesmo que o professor seja discordante com a sua aprovação.

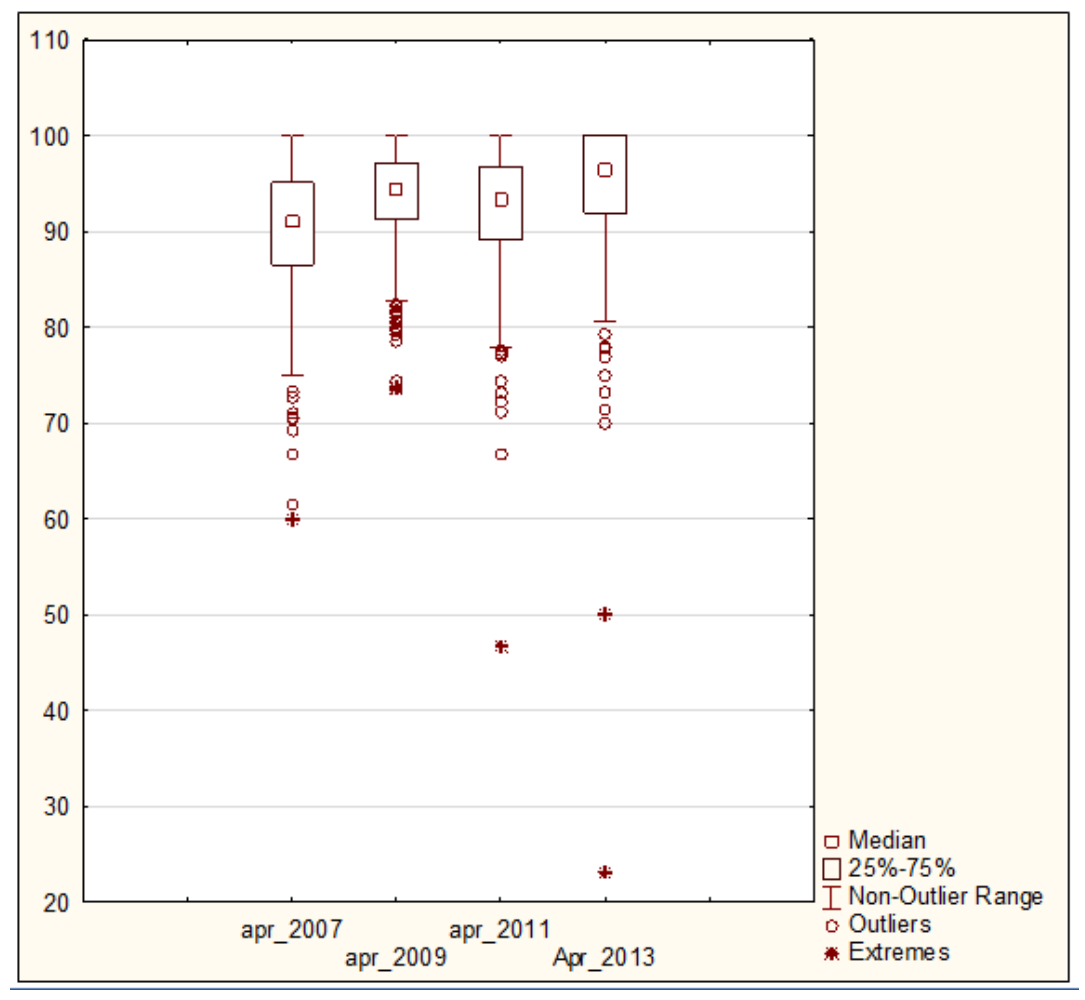

Figura 3.4: Taxa de Aprovação $5^{\circ}$ ano Escola Pública do Distrito Federal.

Das Figuras 3.3 e 3.4 obtém-se que a maioria das escolas tiveram a Taxa de Aprovação acima de $80 \%$, a que contradiz a realidade da Prova Brasil padronizada que mostrou notas abaixo de 50 pontos.

De forma análoga, padronizou-se as notas do $9^{\circ}$ ano.

A média ponderada da nota da Prova Brasil do $9^{\circ}$ ano aponta um crescimento de 2007 para 2009 em Matemática, um decrescimento de 2009 para 2011, um crescimento de 2011 para 2013, enquanto em Português houve um crescimento de 2007 a 2009, um leve crescimento de 2009 para 2011 e um decrescimento de 2011 a 2013. Pela escala de desempenho do INEP, os alunos estão no nível 5 em Português e nível 5 e 6 em Matemática (informação mais detalhada na Tabela A.1 do Apêndice) como mostram as Figuras 3.5 e 3.6 . 


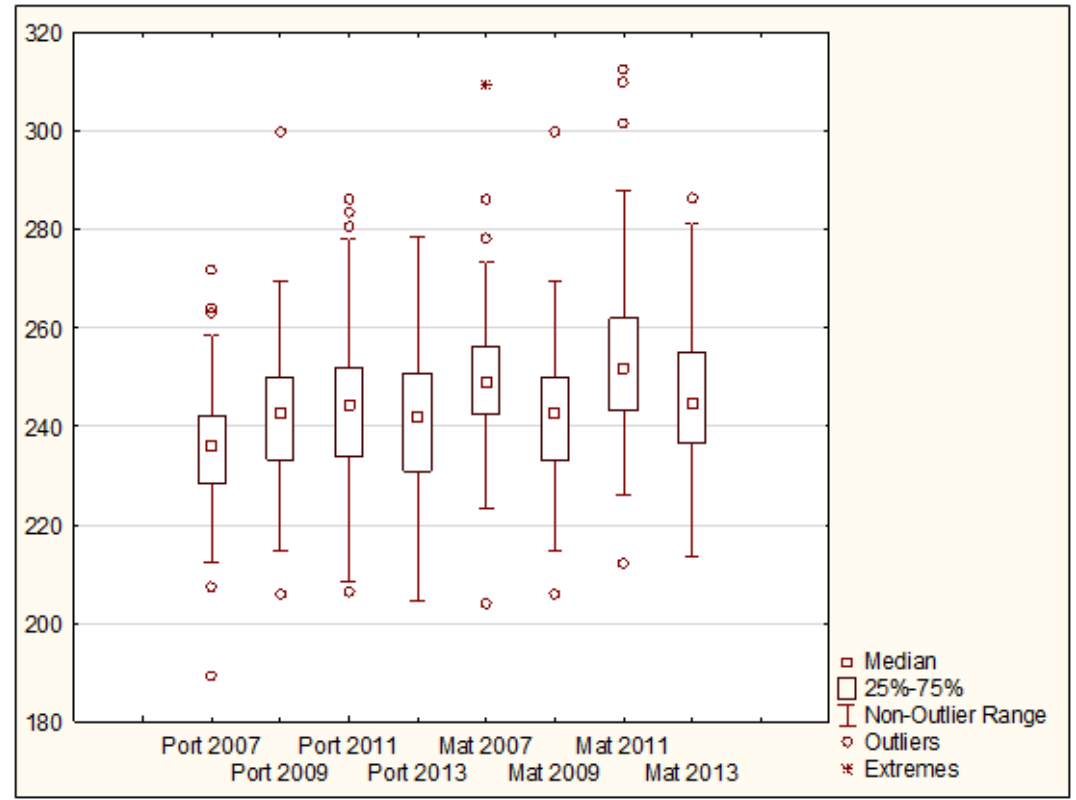

Figura 3.5: Nota da Prova Brasil do $9^{\circ}$ ano da Escola Pública do DF.

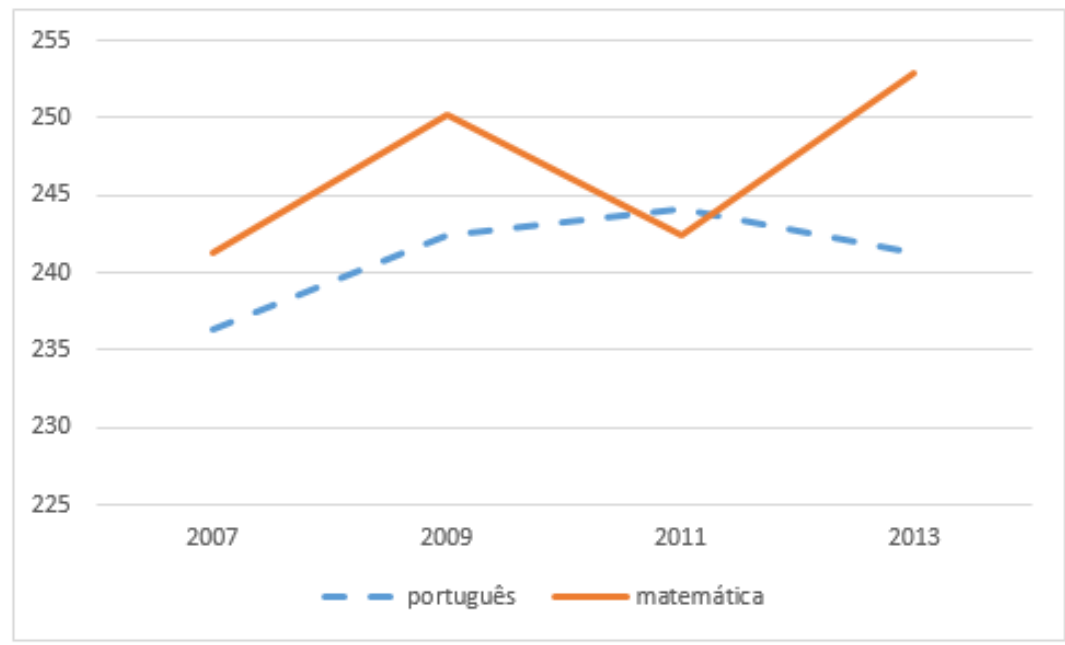

Figura 3.6: Média Ponderada da Prova Brasil, $9^{\circ}$ ano Escola Pública do DF.

Como não há possibilidade de comparar, na forma análoga ao $5^{\circ}$ ano, fez-se a padronização das notas da Prova Brasil, como mostra a Figura 3.7 abaixo: 


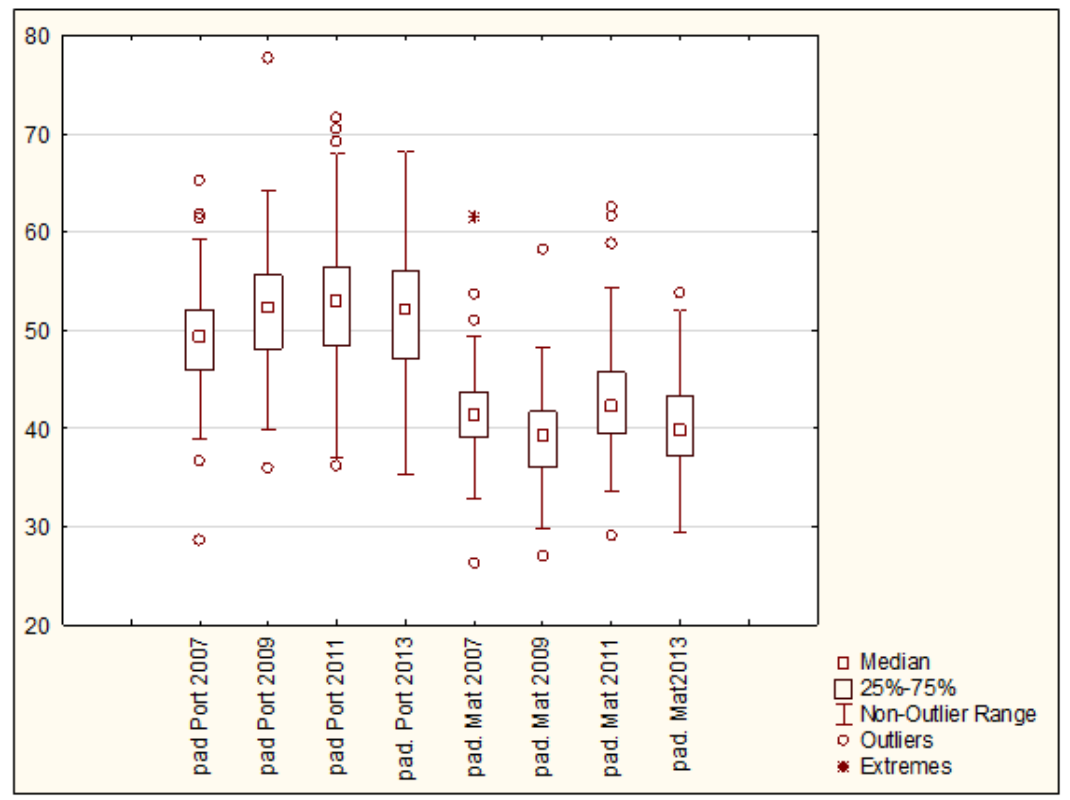

Figura 3.7: Padronização da Nota do $9^{\circ}$ ano da Prova Brasil das Escolas Públicas do DF.

Este gráfico mostra que os alunos tiveram melhor desempenho em Português do que em Matemática. Além disso, a nota de Português foi acima de 50 enquanto a Matemática foi pouco abaixo de 50 pontos.

Por outro lado, o $9^{\circ}$ ano mostra que há mais alunos retidos na série, porém ainda mostra que os alunos passam de série sem dominar o conteúdo proposto de acordo com as Figuras 3.7 e 3.8 .

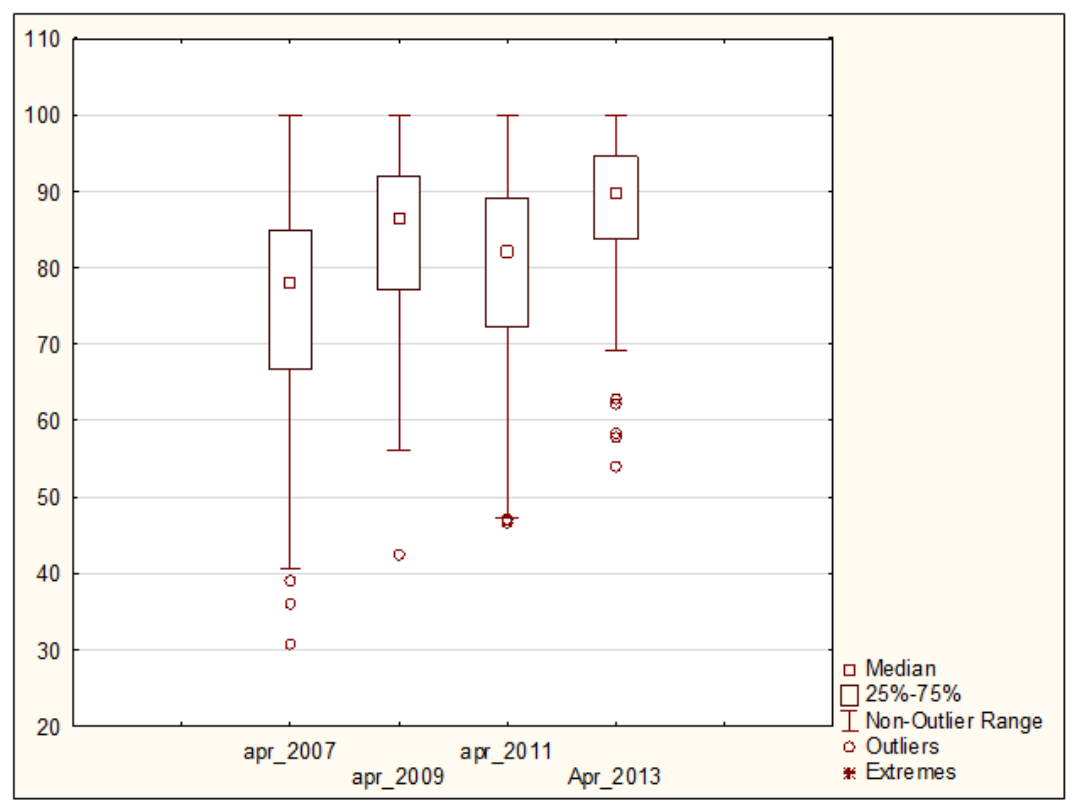

Figura 3.8: Taxa de Aprovação $9^{\circ}$ ano Escola Pública do DF. 
Outro fator importante que foi destacado é a Taxa de Distorção Idade e Série (TDI) como mostra a Figura 3.9, comforme [16]. Temos que essa taxa vai aumentando do $1^{\circ}$ ano (TDI 00) ao $6^{\circ}$ ano (TDI 05) e depois vai decrescendo do $6^{\circ}$ ano (TDI 05) ao $9^{\circ}$ ano (TDI 08). E na Figura 3.10 tem-se o abandono dos alunos. Significa que os alunos estão desistindo de cursar a série antes mesmo de começar o ano letivo, porque o sistema matricula os alunos automaticamente pela continuação do ano letivo, mesmo que ele reprove ou falte muita aula. Por outro lado, quando o aluno não frequenta ou tem pouca frequência no primeiro bimestre esses nomes são retirados do sistema. Por esse motivo a taxa de abandono é baixa. Em razão disso, distorce os dados estatístico dificultando um diagnóstico mais preciso. Além disso, pode-se entender a grande salto da Taxa Distorção Idade e Série do $5^{\circ}$ ano para o $6^{\circ}$ ano devido ao aumento de conteúdo em que os alunos não estão acostumados, sem esquecer que os professores do Ensino Fundamental II são especialistas no conteúdo enquanto no Ensino Fundamental I são pedagogos. E isso contradiz a alta Taxa de Aprovação como mostram as Figuras 3.4 e 3.8. Ou seja, os alunos estão sendo aprovados sem dominar o conteúdo e esses problemas vão acumulando e aumentando ainda mais o abandono e a Taxa de Distorção Idade e Série. Por isso, há uma necessidade de modificar o sistema de recuperação para verificar se este aluno está dominando o conteúdo, além da dependência que na Secretaria da Educação do DF não é levado a sério por falta de normas. Nessas dependências os alunos deveriam ter aulas em horários contrários para sanar suas dificuldades. Para reforçar e tirar dúvidas dos professores dos Ensino Fundamental I e dos alunos que estão em dificuldade poder-se-ia ter professores especialistas para fazer o reforço em horário contrário e na hora da coordenação revisar com os professores. É comum os professores do $6^{\circ}$ ano reclamarem que os alunos não entendem bem operação matemática ou são fracos em leitura. Por outro lado, deveria ter pedagogo no Ensino Fundamental II para sanar a dúvida do docente e proporcionar uma maneira mais eficiente para o professor conduzir a aula. Muitos desses professores acabam imitando um bom professor que tiveram na universidade ou no tempo da escola. Ou querem descontar as dificuldades que eles tiveram e imitam os piores professores que dos quais foram alunos durante seus cursos de graduação. 


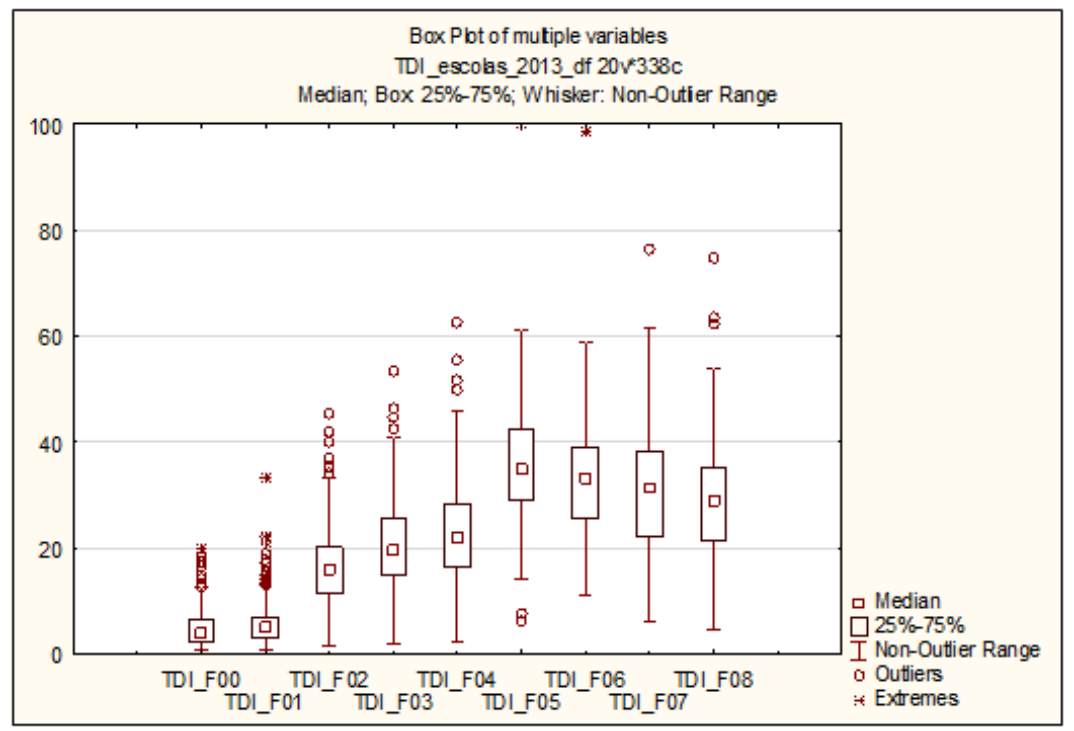

Figura 3.9: Taxa Distorção Idade e Série.

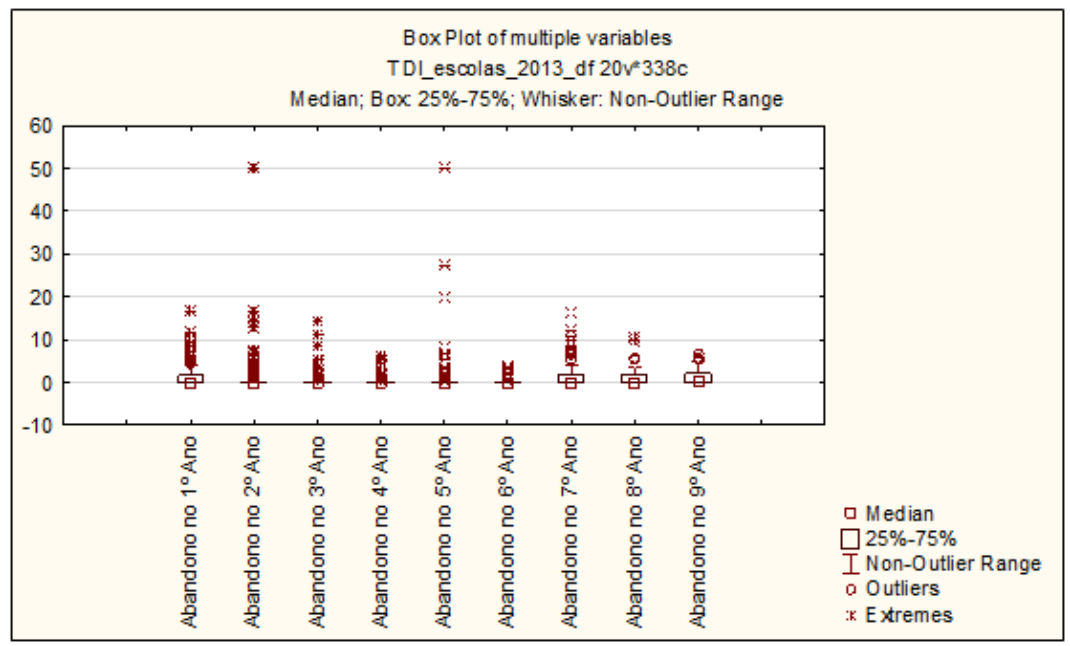

Figura 3.10: Taxa de Abandono por Série.

Também foram analisados os recursos das escolas, número de docentes e titulação, entre outros, para verificar sua influência da qualidade do ensino. Um fato curioso é que entre os professores do $1^{\circ}$ a $5^{\circ}$ ano, a maioria possui pós-graduação, enquanto do $6^{\circ}$ a $9^{\circ}$ ano a maioria não possui pós-graduação, como mostra a Tabela 3.3 .

Tabela 3.3: Titulação dos Professores das Escolas Públicas do GDF em 2013.

\begin{tabular}{l|c|c|c|c|c}
\hline & Especialização & Mestrado & Doutorado & Sem Pós & Total \\
\hline $1^{\circ}$ a $5^{\circ}$ ano & 4997 & 162 & 15 & 4145 & 9319 \\
$6^{\circ}$ a $9^{\circ}$ ano & 3130 & 243 & 30 & 4781 & 8184 \\
\hline Total & 8127 & 405 & 45 & 8926 & 17503 \\
\hline
\end{tabular}


Ou seja, nos $1^{\circ}$ ao $5^{\circ}$ anos, $53,6 \%$ dos professores possuem uma especialização, 1,7\% mestrado, 0,2 \% doutorado e 44,5\% não possuem pós-graduação, conforme a Figura 3.11 .

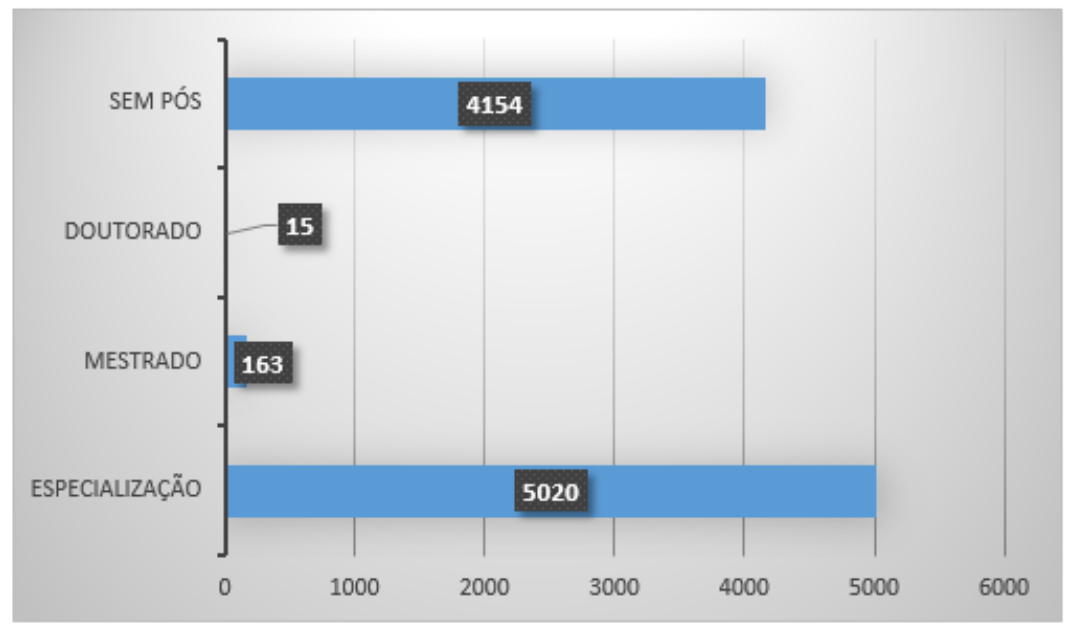

Figura 3.11: Titulação dos Docentes do $1^{\circ}$ a $5^{\circ}$ ano em 2013.

Por outro lado, entre os $6^{\circ}$ ao $9^{\circ}$ anos há mais professores sem pós-graduação do que com especialização, visto que, 38,2\% possuem especialização, 3,0\% mestrado, 0,4\% doutorado e 58,4\% não possuem pós-graduação, conforme a Figura 3.12 .

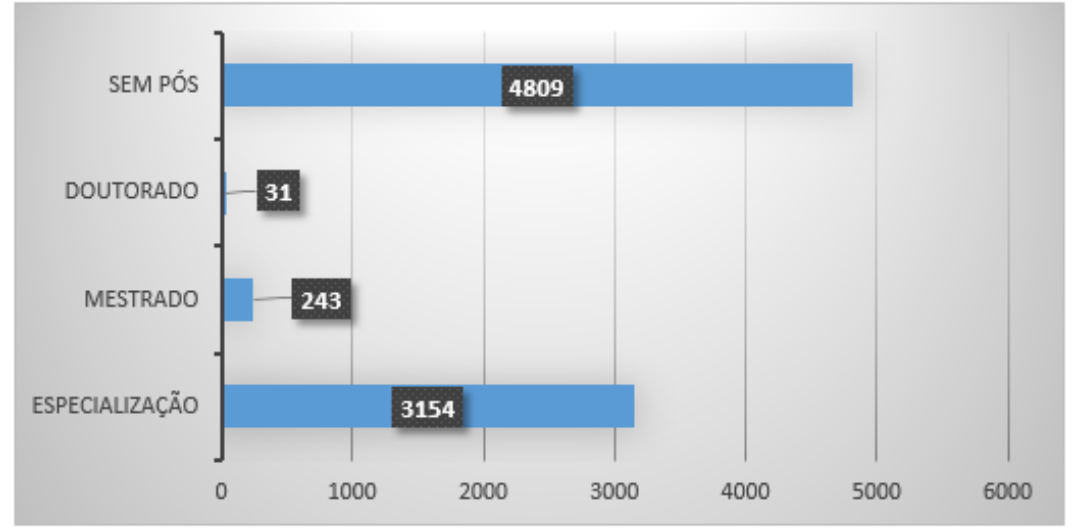

Figura 3.12: Título do Docente $6^{\circ}$ a $9^{\circ}$ ano em 2013.

Outras informações sobre os recursos da escola referem-se a instalações administrativas, didático-pedagógicas e equipamentos disponíveis a professores e alunos, conforme a Tabela 3.4. A informação sobre a disponibilidade destes recursos está no Censo Escolar e permitiu a construção de indicadores que qualificam a infraestrutura da escola. 
Tabela 3.4: Recursos e Equipamentos Pedagógicos.

\begin{tabular}{c|c}
\hline Código & Significado \\
\hline ID_LABORATORIO_INFORMATICA & Laboratório de Informática \\
ID_LABORATORIO_CIENCIAS & Laboratório de Ciências \\
ID_SALA_ATENDIMENTO_ESPECIAL & Sala Atendimento Especial \\
QUADRA & Quadra \\
ID_BIBLIOTECA & Biblioteca \\
ID_PARQUE_INFANTIL & Parque Infantil \\
ID_DEPENDENCIAS_PNE & Dependência PNE \\
ID_REFEITORIO & Refeitório \\
ID_DESPENSA & Despesa \\
ID_ALMOXARIFADO & Almoxarifado \\
PATIO & Pátio \\
ID_AREA_VERDE & Área Verde \\
ID_AEE & Nutendimento Educacional Especializado \\
NUM_SALAS_EXISTENTES & Número de Salas Existentes \\
NUM_SALAS_UTILIZADAS & Número de Salas Utilizadas \\
NUM_EQUIP_TV & Número de Equipamento de TV \\
NUM_EQUIP_DVD & Número de Equipamento de DVD \\
NUM_EQUIP_PARABOLICA & Número Equipamento Copiabólica \\
NUM_EQUIP_COPIADORA & Número Equipamento Impressora \\
NUM_EQUIP_IMPRESSORA & Número Equipamento Som \\
NUM_EQUIP_SOM & Número Equipamento Multimidia \\
NUM_EQUIP_MULTIMIDIA & Número Equipamento de Foto \\
NUM_EQUIP_FOTO & Número de Computadores \\
NUM_COMPUTADORES & Internet \\
\hline ID_INTERNET &
\end{tabular}

\subsection{Análise de Componentes Principais}

Com as variáveis Renda, Prova Brasil, Total de Professor, Porcentagem de Professores sem Pós-Graduação, Porcentagem de Professores com Pós-Graduação, Total de Alunos, Aprovação,Taxa de Distorção Idade e Série, Abandono, Instalação , TV / SALA e Computadores (Comp) - onde as três últimas variáveis foram construídos da secção 3.3 fez-se a Análise de Componentes Principais e com isso gerou-se a Tabela B.1 do Apêndice e a Tabela 3.5 que gera a Figura 3.13 onde o Fator 1 explica a Renda, Prova Brasil e Aprovação com sentido contrário a Total de Alunos, Total de Professores e Taxa de Distorção Idade e Série. Enquanto o Fator 2 explica Professores sem PósGraduação contrapondo com Professores com Pós-Graduação, Instalação, Total de Alunos e Total de Professores. E o Fator 1 e Fator 2 explicam 37,96\% da variabilidade total como mostrado a Figura 3.13. Pode-se analisar cada uma das variáveis como coordenadas de um plano cartesiano, como por a exemplo Renda que é $(0,60 ; 0,18)$. Mas a intenção é analisar os grupos as quais eles pertencem que será destacado. Destaca-se 
que a Renda, Prova Brasil e Aprovação se contrapõem com Taxa Distorção Idade e Série e Professores sem Pós-Graduação. Além disso, também se contrapõem com o Total de Alunos, Total de Professores e Instalação.

Tabela 3.5: Autovalores $5^{\circ}$ ano.

\begin{tabular}{c|c|c|c|c}
\hline & Autovalores & \% Total & Acumulativo & Acumulativo \\
\hline 1 & 2,76 & 21,23 & 2,76 & 21,23 \\
2 & 2,18 & 16,73 & 4,93 & 37,96 \\
3 & 1,71 & 13,13 & 6,64 & 51,10 \\
4 & 1,60 & 12,34 & 8,25 & 63,43 \\
5 & 1,15 & 8,84 & 9,39 & 72,27 \\
6 & 0,84 & 6,46 & 10,23 & 78,72 \\
7 & 0,81 & 6,23 & 11,04 & 84,95 \\
8 & 0,58 & 4,47 & 11,62 & 89,42 \\
9 & 0,53 & 4,11 & 12,15 & 93,53 \\
10 & 0,38 & 2,90 & 12,54 & 96,43 \\
11 & 0,33 & 2,50 & 12,86 & 98,94 \\
12 & 0,14 & 1,06 & 13,00 & 100,00 \\
\hline
\end{tabular}

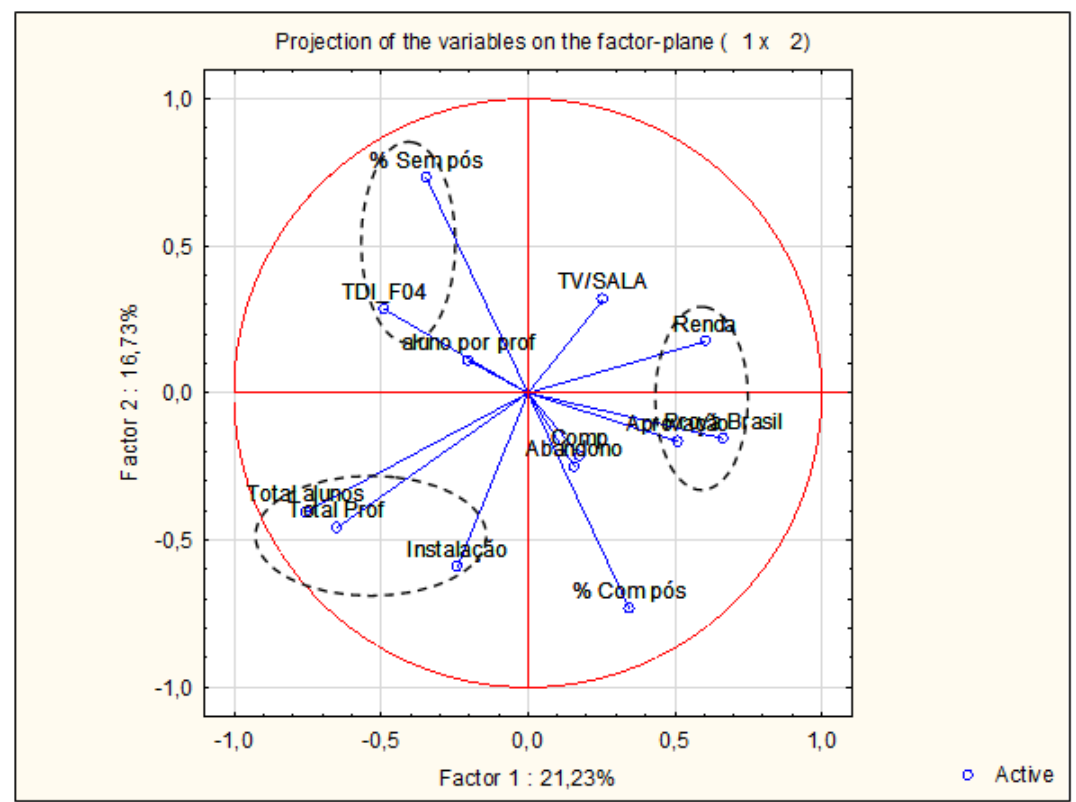

Figura 3.13: Análise de Componentes Principais Fator 1 e 2 do $5^{\circ}$ ano.

De forma análoga, a Análise de Componentes Principais para o $9^{\circ}$ ano gera as Tabelas B.2 do Apêndice e 3.6 onde tem-se que o Fator 1 explica Total de Professores, Porcentagem de Professores sem Pós-Graduação e Total de Alunos com sentido contrário a Renda, Aprovação e Porcentagem de Professores com Pós-Graduação, enquanto o Fator 2 explica a Taxa Distorção Idade e Série no sentido contrário a Aprovação, Aluno por Professor e a Prova Brasil. E o Fator 1 e Fator 2 explicam 
38,97\% da variabilidade total como mostra a Figura 3.14. Pode-se analisar cada uma das variáveis como coordenadas de um plano cartesiano, como por exemplo a Renda que é $(-0,63 ;-0,12)$. Mas a intenção é analisar os grupos as quais eles pertencem e isso é o que será destacado. Nesse sentido a Taxa de Distorção Idade e Série se contrapõem com Aprovação e Prova Brasil. Além disso, Total de Professores, Total de Aluno e Porcentagem de Professores sem Pós-Graduação se contrapõem com Porcentagem de professores com Pós-Graduação e Renda.

Tabela 3.6: Autovalores $9^{\circ}$ ano.

\begin{tabular}{l|c|c|c|c}
\hline & Autovalores & \% Total & Acumulado & Acumulado \\
\hline 1 & 3,29 & 25,32 & 3,29 & 25,32 \\
2 & 1,77 & 13,64 & 5,07 & 38,97 \\
3 & 1,57 & 12,05 & 6,63 & 51,01 \\
4 & 1,38 & 10,60 & 8,01 & 61,62 \\
5 & 1,22 & 9,37 & 9,23 & 71,00 \\
6 & 1,14 & 8,79 & 10,37 & 79,79 \\
7 & 0,65 & 4,96 & 11,02 & 84,75 \\
8 & 0,58 & 4,43 & 11,59 & 89,19 \\
9 & 0,54 & 4,18 & 12,14 & 93,37 \\
10 & 0,44 & 3,37 & 12,58 & 96,74 \\
11 & 0,40 & 3,07 & 12,98 & 99,81 \\
12 & 0,02 & 0,19 & 13,00 & 100,00 \\
\hline
\end{tabular}

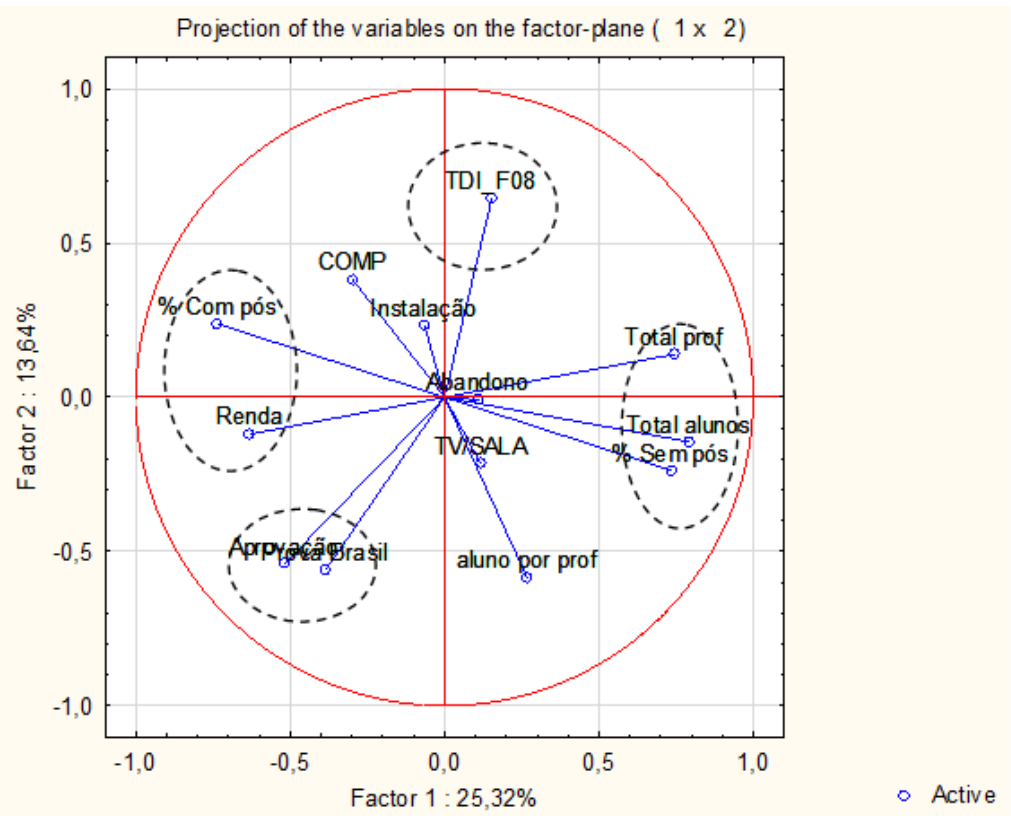

Figura 3.14: Análise de Componentes Principais Fator 1 e 2 do $9^{\circ}$ ano. 


\subsection{Seleção das escolas}

Foram construídos indicadores para resumir os aspectos de um grupo de variáveis relacionadas a alguma característica da escola. A maioria das variáveis que apresentam características das escolas é do tipo categórica e possui uma ordem natural: se a escola possui uma determinada dependência, se a escola possui um grande número de determinados equipamentos e se os equipamentos são devidamente utilizados na escola. É intuitivo presumir que alunos de uma escola com uma boa estrutura com relação a dependências, equipamentos e utilização dos recursos disponíveis na instituição têm melhores condições de aprendizagem e, em consequência, tendem a obter melhores desempenhos na Prova Brasil.

Os indicadores construídos têm como objetivo quantificar a qualidade da escola quanto a existência de dependências, quantidade e utilização de equipamentos e recursos disponíveis nas instituições, para testar a viabilidade de avaliá-las em um mesmo modelo de eficiência.

Inicialmente há dois tipos de variáveis que compõem os indicadores: qualitativas dicotômicas do tipo "Sim" ou "Não" (variáveis de existência de dependências e utilização de recursos) e variáveis discretas (quantidade de equipamentos).

\section{Indicador da existência de instalações}

Escolhido um conjunto de instalações, adotou-se como indicador da existência de instalações a proporção dessas instalações que existem na escola.

As instalações consideradas na construção do indicador foram:

1. Laboratório de informática;

2. Laboratório de ciências;

3. Sala de atendimento especial;

4. Quadra de esportes;

5. Biblioteca;

6. Dependência de PNE (Portador de Necessidades Especiais);

7. Refeitório;

8. Despensa;

9. Almoxarifado; 
10. Pátio;

11. Área verde;

12. Atendimento Educacional Especializado (AEE)

Instalações relativas a outras dependências não foram consideradas porque quase todas as escolas possuem (como por exemplo sala da direção, sala de professores, secretaria, banheiro, internet, entre outros), ou porque nenhuma escola possui, como por exemplo de banheiro externo a escola.

Além disso, foi construído a variável televisão por sala de aula (TV/SALA) porque a televisão atual substitui vários aparelhos como som, kit multimídia, DVD. A $T V / S A L A$ é um grande recurso que o professor pode acoplar no computador para fazer diversos trabalhos como gráfico de funções na matemática ou apresentar slides. Sem esquecer, alunos podem fazer slide em pdf e acoplar direto na televisão evitando diversos vírus.

Outra variável considerada foi Número de Computadores vezes Números de Salas sobre Números de alunos (Comp), por ser um recurso importante aos alunos, pois nem sempre têm computadores em suas casas. Por outro lado, o professor poderá ensinar aos alunos utilizar aplicativos que facilitam o aprendizado, como por exemplo o Winplot, Excel.

A partir da formação dos indicadores, que representam características estruturais das instituições, as escolas foram separadas em grupos cujos elementos apresentam indicadores com características semelhantes. Neste sentido, escolas que apresentam indicadores da infraestrutura muito distintos não devem ser comparadas. Para classificar as escolas em grupos homogêneos, a Análise de Conglomerados foi utilizada. Algumas escolas apresentam indicadores com valores elevados e outras com valores baixos. Por este motivo, o método de análise de conglomerados utilizado foi o de variância mínima ( $W$ ard), uma técnica hierárquica aglomerativa que consiste em tratar cada elemento inicialmente como um conglomerado. As combinações de escolas que produzem as menores variâncias são agrupadas em um conglomerado e, em seguida, são calculadas as novas variâncias dos conglomerados formados. A técnica se repete até que um conglomerado contendo todas as escolas seja formado. O objetivo deste método é obter um número de grupos que produzam as menores variâncias internas. Os indicadores possuem escalas diferenciados, portanto para a aplicação da técnica de formação de grupos os indicadores serão transformados de forma que todos possuam média 0 (zero) e variância 1 (um). Desta forma as escalas dos indicadores não exercem influência na aplicação da técnica. A medida de similaridade entre os elementos utilizada neste método é a distância euclidiana. Com isso, constroe-se um dendograma 
com as variáveis Renda da Região Administrativa (Renda), Instalações, TV/SALA e Comp.

\subsubsection{Seleção das escolas do $5^{\circ}$ ano}

Com as variáveis propostas acima aplicou-se Análise de Conglomerados nas 388 escolas do $5^{\circ}$ ano. Observou-se duas estruturas consistentes de grupos: uma delas com quatro grupos, basicamente determinados, cada um deles, por uma das variáveis utilizadas; e outra em dois grupos separando escolas bem equipadas em regiões de renda mais alta e escolas menos equipadas em regiões de renda mais baixa. Considerando os objetivos do trabalho, adotou-se a classificação em dois grupos. Assim, o primeiro (Conglomerado 1) tem 85 escolas e se caracteriza por escolas melhores equipadas em regiões de renda mais alta, enquanto o segundo (Conglomerado 2), com 253 escolas em regiões de renda mais baixa e piores condições de infraestrutura, como mostram as Figuras 3.15 e 3.16 .

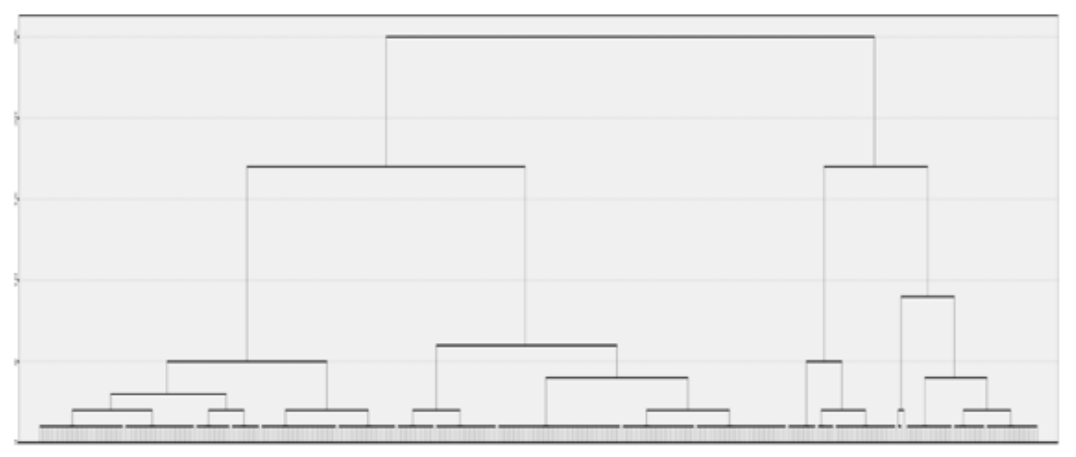

Figura 3.15: Dendograma $5^{\circ}$ ano.

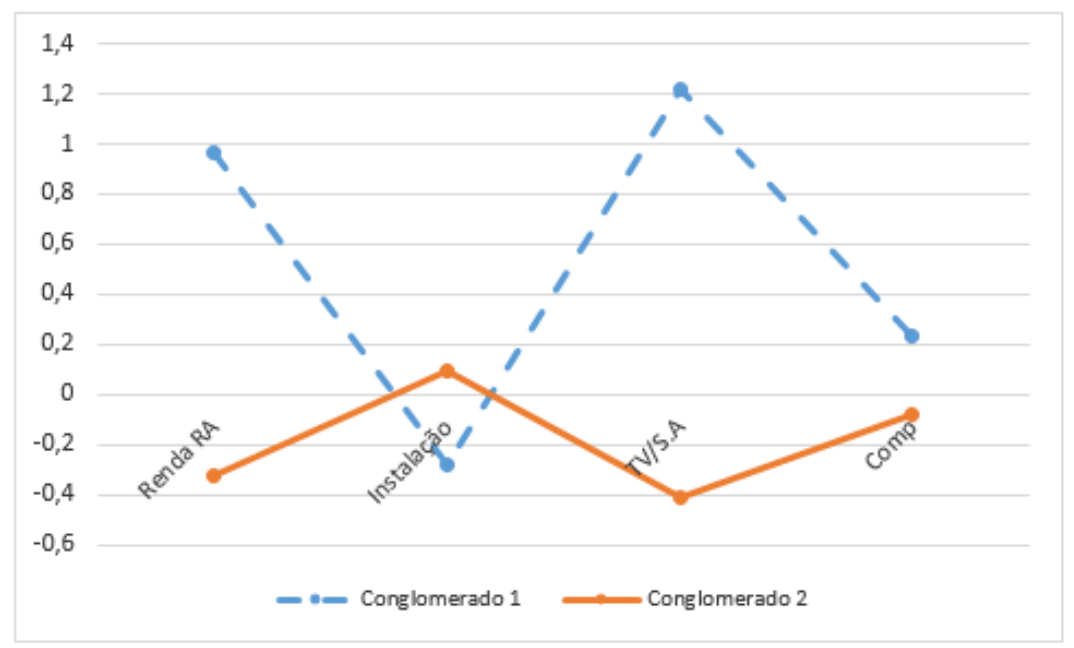

Figura 3.16: Média Padronizada das Variáveis Separadas por Conglomerado 1 e 2. 
As escolas do $1^{\circ}$ a $5^{\circ}$ ano que estão localizados em regiões mais ricas e com melhores infraestrutura possuem taxa de aprovação praticamente idêntica às escolas que estão localizados em regiões mais pobres e com pior infraestrutura, conforme se vê na Figura 3.17 .

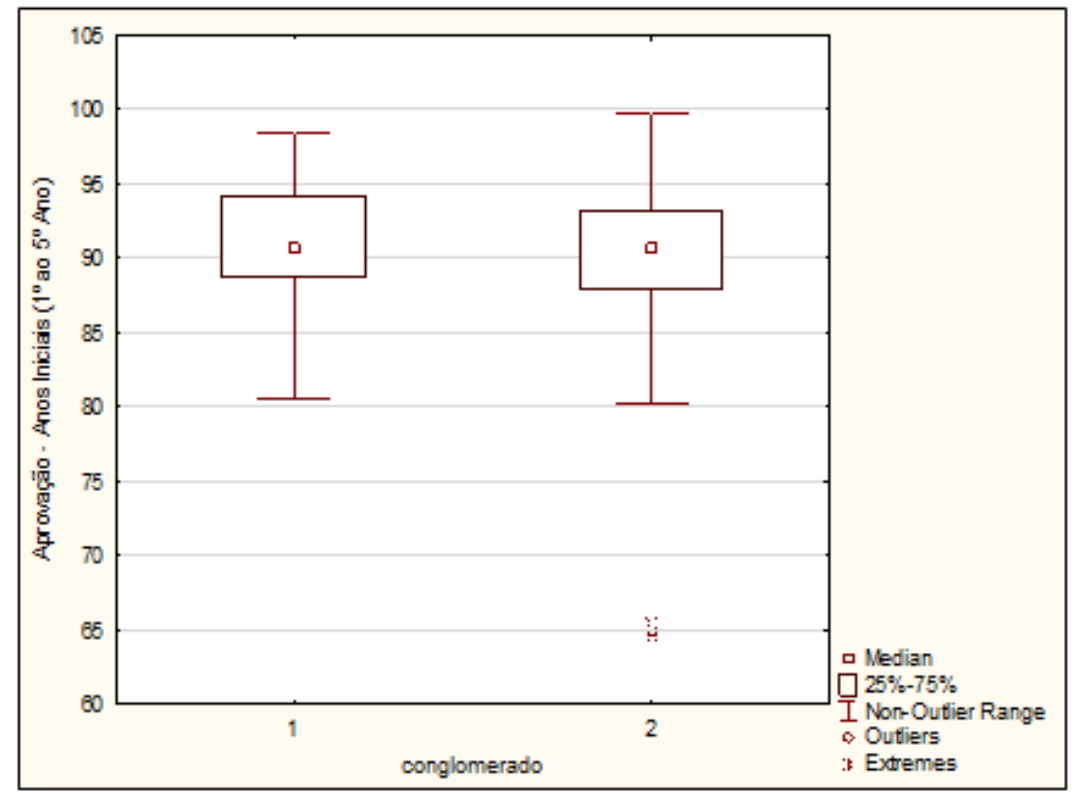

Figura 3.17: Box-Plot de Taxa de Aprovação Segundo Conglomerado 1 e 2.

Por outro lado, a Figura 3.18 mostra que no Conglomerado 1 os alunos possuem melhores rendimentos na Prova Brasil que no Conglomerado 2.

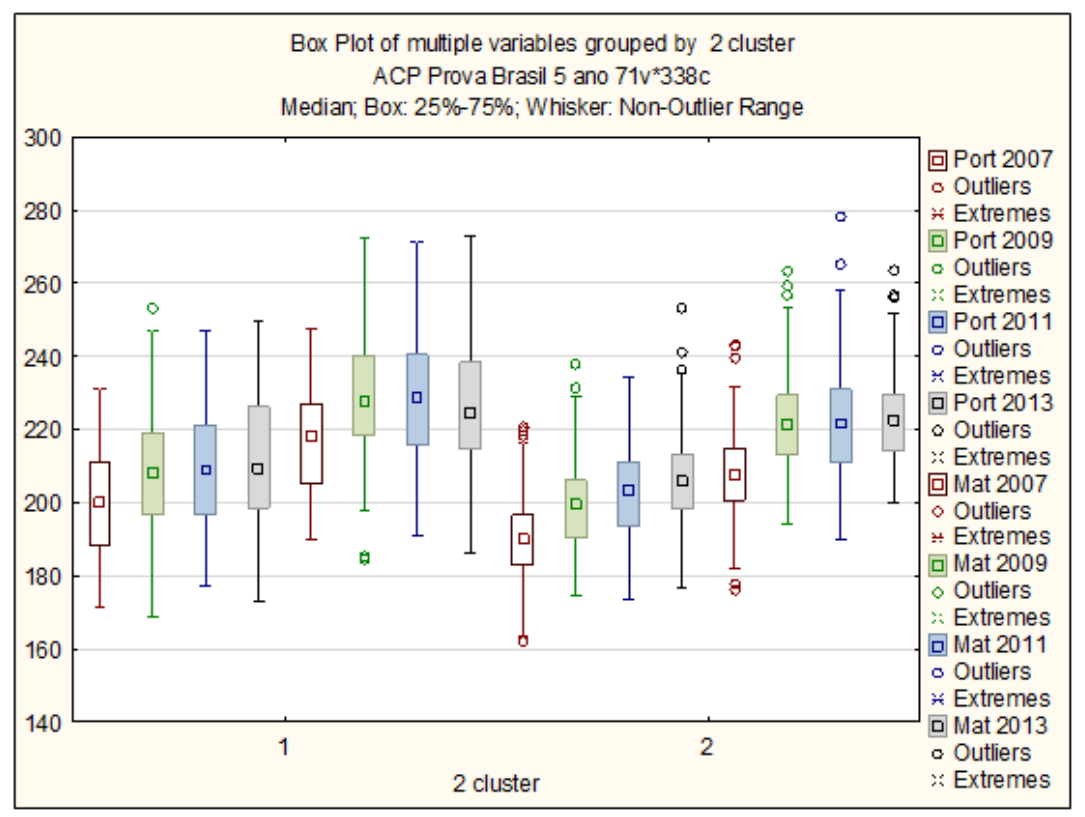

Figura 3.18: Nota da Prova Brasil segundo Conglomerados 1 e 2. 
Como foi dito acima, trabalha-se com a padronização da nota da Prova Brasil e pelo gráfico de Box-Plot tem-se a nota de Português 2013, Matemática 2013 e Média dessas duas notas. Como mostra a Figura 3.19 as três notas têm o mesmo comportamento e com isso será utilizado na análise de eficiência a Média da Prova Brasil padronizada como descritora de desempenho na Prova Brasil.

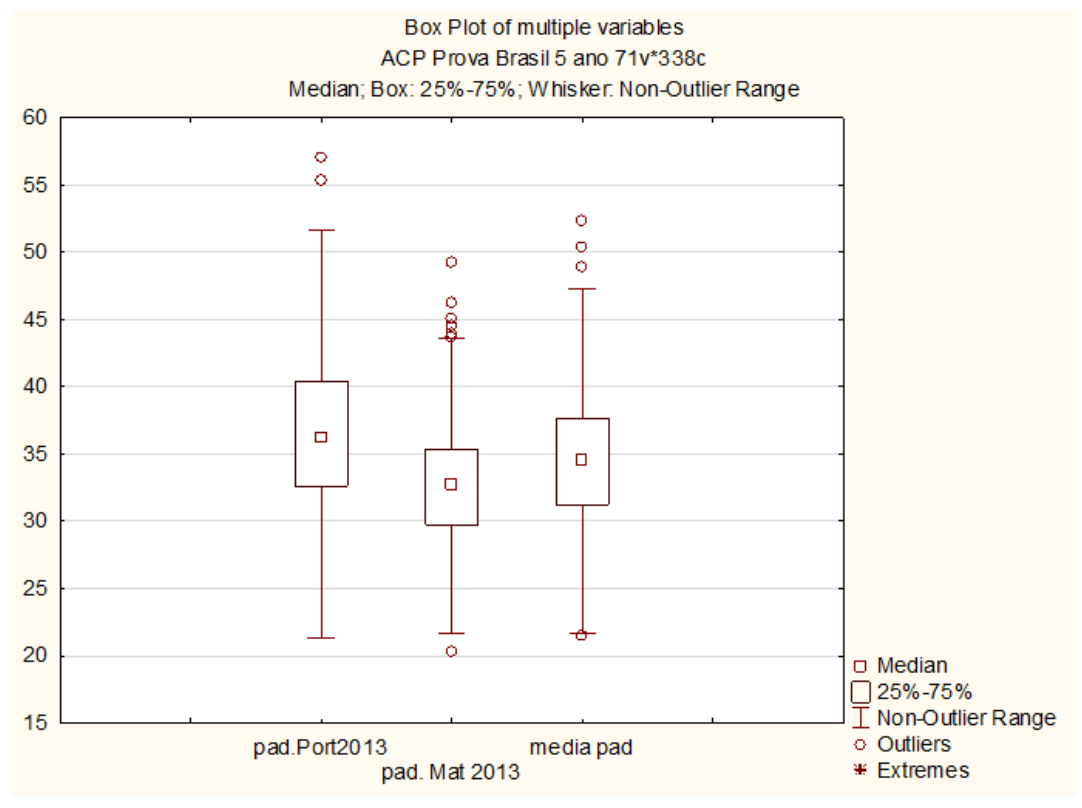

Figura 3.19: Box-Plot da Prova Brasil de Português, Matemática e Média dos dois em 2013.

A análise identificou dois conglomerados no $5^{\circ}$ ano com características diferentes de renda e infraestrutura. Assim a aplicação de DEA se fez dentro de cada Conglomerado.

\subsubsection{Seleção das escolas $9^{\circ}$ ano}

Com as mesmas variáveis que são Renda da Região Administrativa, Instalações, TV/SALA e Comp, novamente identificou-se dois conglomerados com as mesmas características encontradas no $5^{\circ}$ ano conforme as Figuras 3.20 e 3.21. A análise de conglomerados sugere a formação de dois conglomerados: o primeiro (Conglomerado 1) tem 60 escolas e se caracteriza por escolas melhores equipadas em regiões de renda mais alta, enquanto o segundo (Conglomerado 2), com 109 escolas em regiões de renda mais baixa e piores condições de infraestrutura.

A Análise de Conglomerados identificou dois conglomerados no $9^{\circ}$ ano com características diferentes de renda e infraestrutura. Assim a aplicação de DEA se fez dentro de cada conglomerado. 


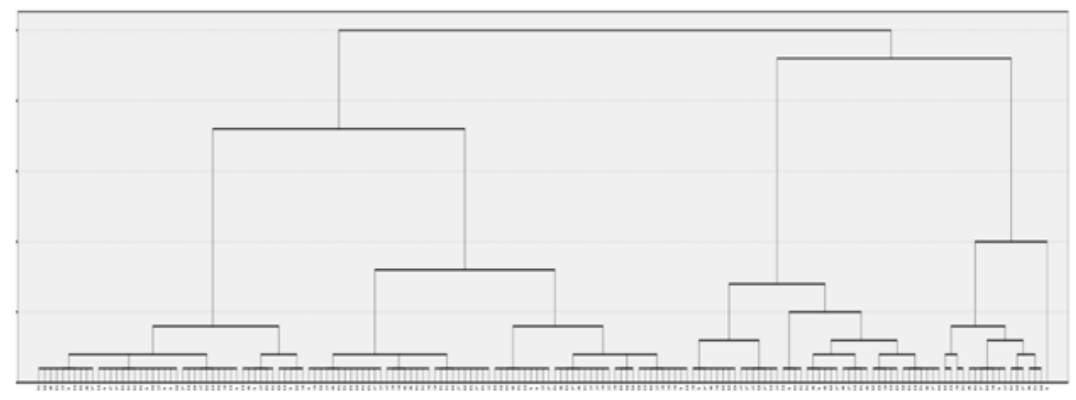

Figura 3.20: Dendograma $9^{\circ}$ ano.

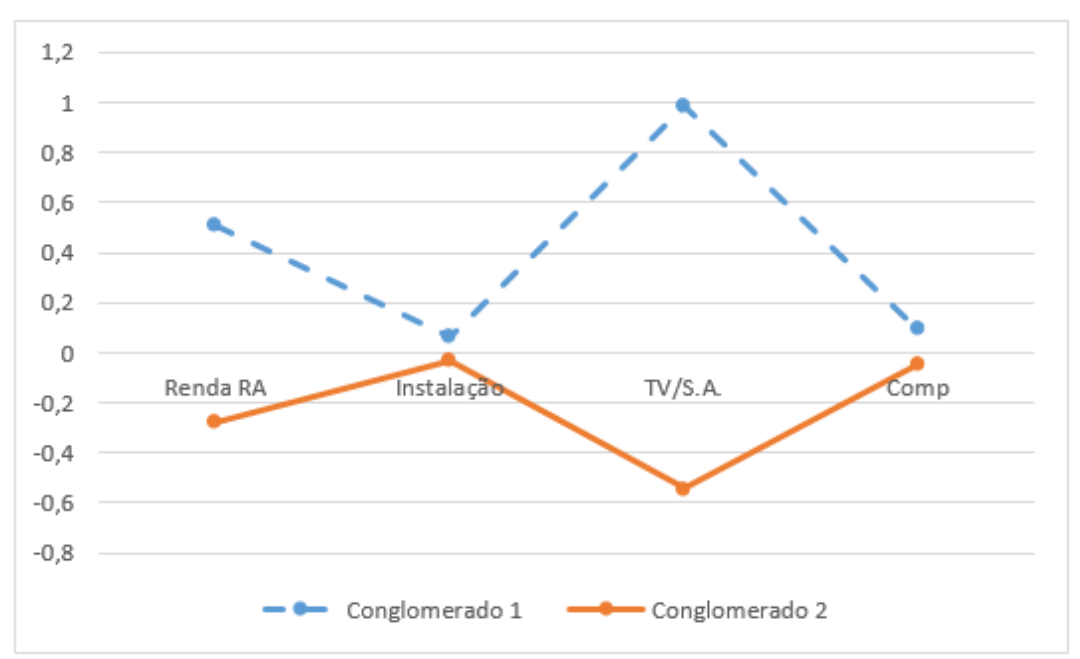

Figura 3.21: Média Padronizada das Variáveis Separados por Conglomerado 1 e 2.

Pela Figura 3.22, tem-se a divisão de dois grandes grupos que chamaremos de Conglomerado 1 e Conglomerado 2. Na divisão, os dois conglomerados são praticamente idênticos em termos da taxa de aprovação dos alunos do $6^{\circ}$ ao $9^{\circ}$ ano. 


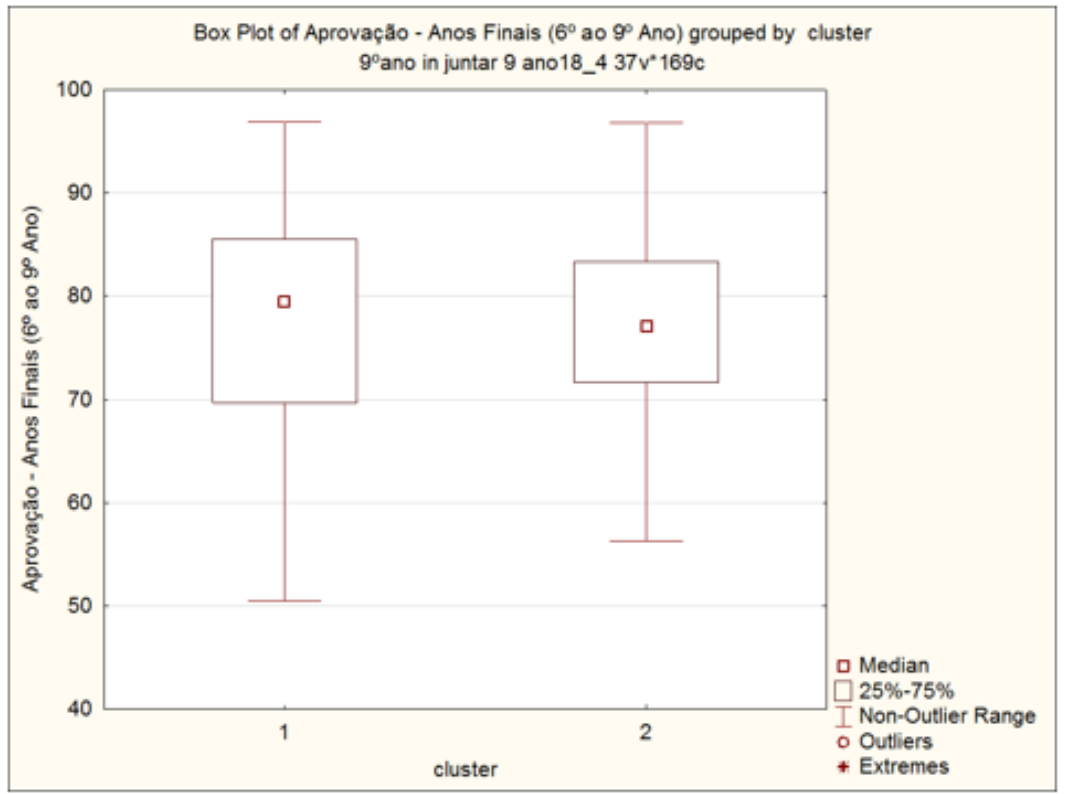

Figura 3.22: Box-Plot de Taxa de Aprovação Segundo Conglomerado 1 e 2.

Por outro lado, a Figura 3.23 mostra que no Conglomerado 1 os alunos possuem melhores rendimentos na Prova Brasil que no Conglomerado 2.

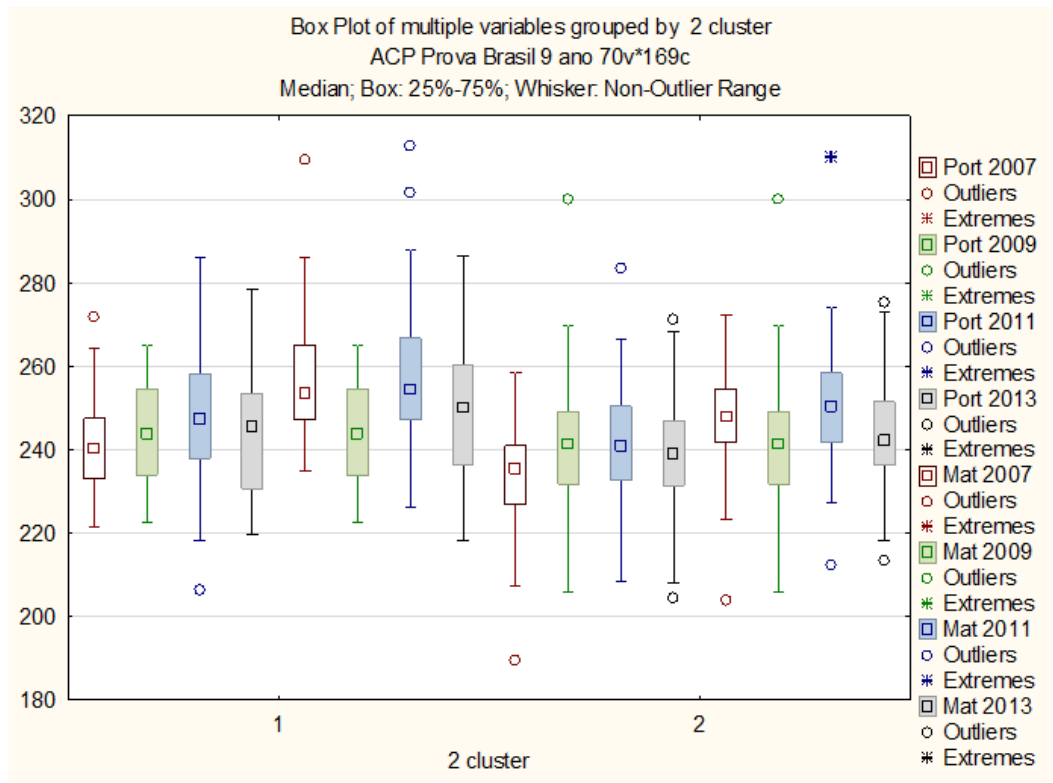

Figura 3.23: Nota da Prova Brasil Segundo Conglomerado 1 e 2. 


\section{Capítulo 4}

\section{Modelo DEA}

Para construir o modelo DEA de fronteira de retornos variáveis a escala (BCC) com a direção de aumento de produtividade, pois a intenção é aumentar a qualidade das escolas e levando-se em consideração a limitação do modelo CCR o qual pode criar objetivo inalcançável, fez-se a opção do modelo BCC. Aplicou-se o procedimento de seleção de variáveis de Norman \& Stoker a cada um dos quatro conglomerados identificados. Além disso, para medir a eficiência que é uma razão de produto sobre insumo, tem-se que identificar quais elementos são insumos, pois estes são variáveis utilizados nas escolas para chegar a um determinado resultado. E quais elementos são o produto que são as variáveis resultados. Neste caso os insumos são Instalações, Comp, TV/SALA, Número de Professores, Titulação dos Professores e os produtos são resultado da Prova Brasil, Taxa de Aprovação, Número de Alunos.

\subsection{Modelo DEA $5^{\circ}$ ano Conglomerado 1}

Seguindo a metodologia de Norman \& Stoker, o primeiro modelo consiste de variáveis com maior correlação e estas são Total de Alunos e Total de Professores. Com isso, será construído o primeiro modelo do DEA1, pois a correlação de Total de Alunos e Total de Professores é 0,92 conforme a Tabela B.3 do Apêndice. Tem-se a expressão:

$$
D E A 1=\frac{q_{1} \cdot \text { Total de Alunos }}{p_{1} \cdot \text { Total de Professores }} .
$$

A Figura 4.1 apresenta a fronteira de eficiência, enquanto a Tabela 4.1 identifica as escolas eficientes obtidas com modelo DEA1. 


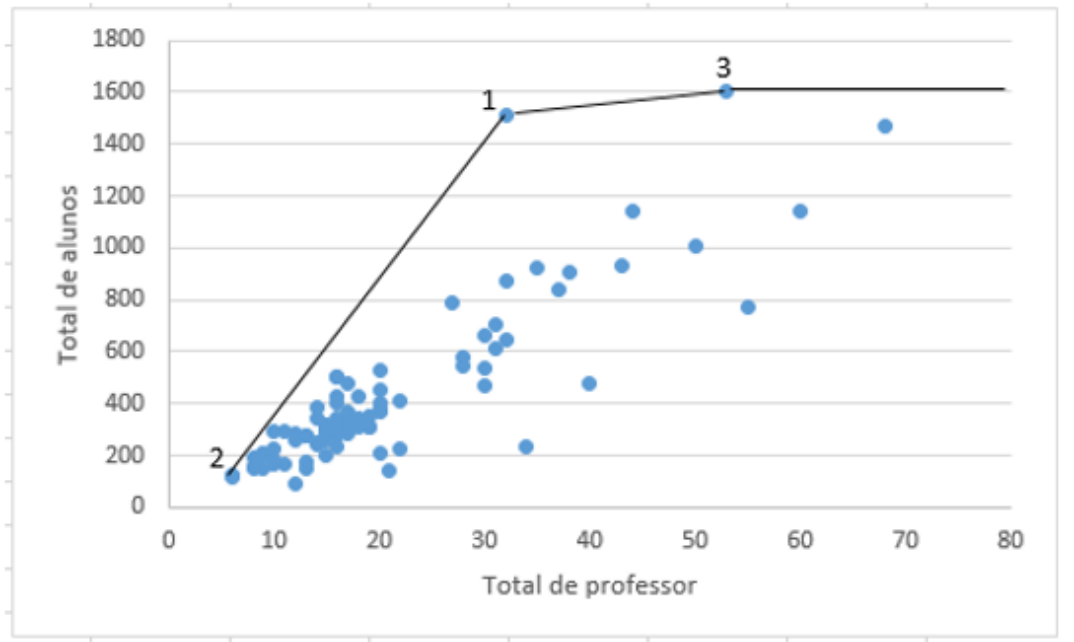

Figura 4.1: DEA1, 5 ano, Conglomerado 1.

Tabela 4.1: Escolas eficientes do DEA1.

\begin{tabular}{l|c|c}
\hline Eficientes & Total de professores & Total de alunos \\
\hline 1 - CEF 02 de Brazlândia & 53 & 1600 \\
2 - EC Aguilhada & 6 & 128 \\
3 - CEF 02 da Estrutural & 32 & 1509 \\
\hline
\end{tabular}

A EC Aguilhada é eficiente em função do seu porte. Por ter o menor número de professores e menor número de alunos do sistema ela não pode ser escrita como combinação convexa das demais escolas, sendo assim, considerada eficiente em razão da adoção do modelo DEA de retorno as variáveis a escala. O CEF 02 da Estrutural domina a relação Total de Alunos pelo Total de Professores. O CEF 02 de Brazlândia tem esta produtividade menor que o CEF 02 da Estrutural, porém é maior em relação aos números de alunos, não podendo assim ser descrito pelas demais escolas eficientes identificadas.

Analisando a associação entre a medida de eficiência construída pelo DEA1 e as demais variáveis observou-se uma correlação negativa entre DEA 1 e a média da Prova Brasil ( $\mathrm{r}=-0,24$, conforme Tabela B.3 do Apêndice). Com isso, seguindo o procedimento de Norman \& Stoker, a variável média da Prova Brasil foi incluída a função de desempenho resultando o modelo DEA2:

$$
D E A 2=\frac{q_{1} \cdot \text { Total de Alunos }+q_{2} \cdot \text { média da Prova Brasil }}{p_{1} \cdot \text { Total de Professores }} .
$$

Com esse modelo duas novas escolas foram consideradas eficientes perfazendo um total de cinco escolas eficientes no modelo DEA2, conforme a Figura 4.2 e a Tabela 4.2 . 
Tabela 4.2: Escolas eficientes DEA 2, $5^{\circ}$ ano, Conglomerado 1.

\begin{tabular}{l|c|c|c}
\hline Escolas eficientes & Total de Professores & Total de alunos & Prova Brasil \\
\hline 1 - EC 106 Norte & 17 & 332 & 52,29 \\
2 - CEF 02 de Brazlândia & 53 & 1600 & 33,41 \\
3 - EC Kanegae & 6 & 119 & 45,80 \\
4 - EC Aguilhada & 6 & 128 & 21,48 \\
5 - CEF 02 da Estrutural & 32 & 1509 & 28,55 \\
\hline
\end{tabular}

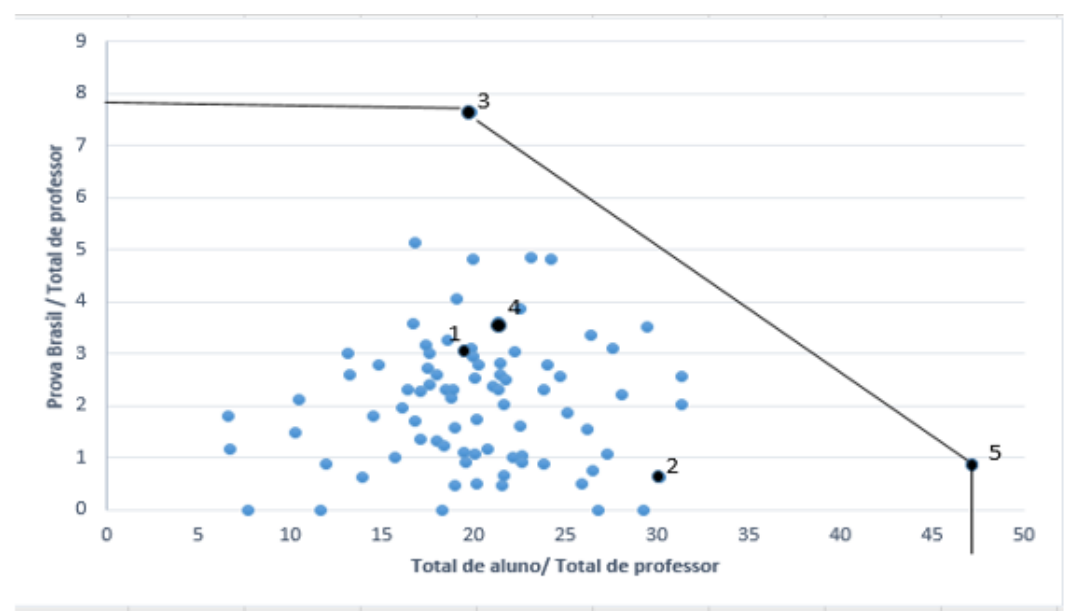

Figura 4.2: DEA 2, Conglomerado 1, $5^{\circ}$ ano.

A Figura 4.1 e a Figura 4.2 têm estruturas totalmente diferentes. A primeira figura apresenta uma relação produto por insumo tradicional em modelos de produção tendo no eixo da abscissa o número de professores (insumo) e na ordenada o número de alunos matriculados (produto). A segunda é uma estrutura de produtividades parciais, tendo no eixo da abscissa a razão entre Total de Alunos e Total de Professores, ou seja, uma razão de produto por insumo. No eixo da ordenada tem-se a razão entre a nota média na Prova Brasil e o total de professor que também é outra razão de produto por insumo. As escolas consideradas eficientes no modelo DEA1 continuam eficientes no modelo DEA2 por características da DEA. Além dessas, o modelo DEA2 identificou duas outras escolas eficientes que são EC 106 NORTE (que domina a nota da Prova Brasil) e a EC KANEGAE (que domina a relação Prova Brasil por Professor) .

A variável taxa de aprovação possuir maior correlação com DEA2 em relação aos dados que não foram utilizados. Construiu-se o DEA3 que é:

$$
D E A 3=\frac{q_{1} \cdot \text { Total de Alunos }+q_{2} \cdot \text { média da Prova Brasil }+q_{3} \cdot \text { Aprovação }}{p_{1} \cdot \text { Total de Professores }} .
$$

Com esse modelo, 78 escolas das 85 atribuíram pesos insignificantes na variável Prova Brasil e pesos máximos para a variável Taxa de Aprovação, inviabilizando a proposta de usar as notas da Prova Brasil como medida da qualidade do 
ensino. Isto é consequência da Taxa de Aprovação não diferenciar as escolas, uma vez que todas elas têm nesta variável um valor muito alto. Com isso, adotou-se o modelo DEA2 para a análise de eficiência das escolas do $5^{\circ}$ ano, Conglomerado 1.

$$
D E A 2=\frac{q_{1} \cdot \text { Total de Alunos }+q_{2} \cdot \text { média da Prova Brasil }}{p_{1} \cdot \text { Total de Professores }}
$$

\subsection{Modelo DEA - $5^{\circ}$ ano Conglomerado 2 e $9^{\circ}$ ano Conglomerados 1 e 2}

O mesmo critério de seleção de variáveis foi aplicado ao $5^{\circ}$ ano Conglomerado 2, $9^{\circ}$ ano Conglomerado 1 e $9^{\circ}$ ano Conglomerado 2 e obteve-se o mesmo modelo. Assim o modelo DEA 2 foi o modelo adotado para análise de eficiência em ambos os grupos (Conglomerado 1 e Conglomerado 2) nos dois níveis de ensino (Ensino Fundamental I e Ensino Fundamental II).

\subsection{Aplicação dos Modelos DEA}

\subsection{1 $\quad 5^{\circ}$ ano Conglomerado 1}

Aplicando-se o modelo DEA2 às escolas do $5^{\circ}$ ano Conglomerado1 identificouse cinco escolas eficientes conforme a Tabela 4.3 e a Figura 4.3 . As razões das eficiências dessas escolas foram explicadas na seção 3.3 do Capítulo 3.

Tabela 4.3: Escolas eficientes DEA 2, $5^{\circ}$ ano, Conglomerado 1.

\begin{tabular}{l|c|c|c}
\hline Escolas eficientes & Total de Professores & Total de alunos & Prova Brasil \\
\hline 1 - EC 106 Norte & 17 & 332 & 52,29 \\
2 - CEF 02 de Brazlândia & 53 & 1600 & 33,41 \\
3 - EC Kanegae & 6 & 119 & 45,80 \\
4 - EC Aguilhada & 6 & 128 & 21,48 \\
5 - CEF 02 da Estrutural & 32 & 1509 & 28,55 \\
\hline
\end{tabular}

Para cada escola considerada ineficiente, o DEA identifica as escolas de referências e indica possibilidade de aumento da produtividade baseadas na projeção do plano de operação executado pela escola na fronteira de eficiência, gerando dois conjuntos de metas:

1. meta proporcional, obtida pela expansão proporcional máxima da produção, representada na medida de eficiência obtida (distância à fronteira);

2. meta global, que acresce à meta proporcional eventuais folgas na produção de resultados. 


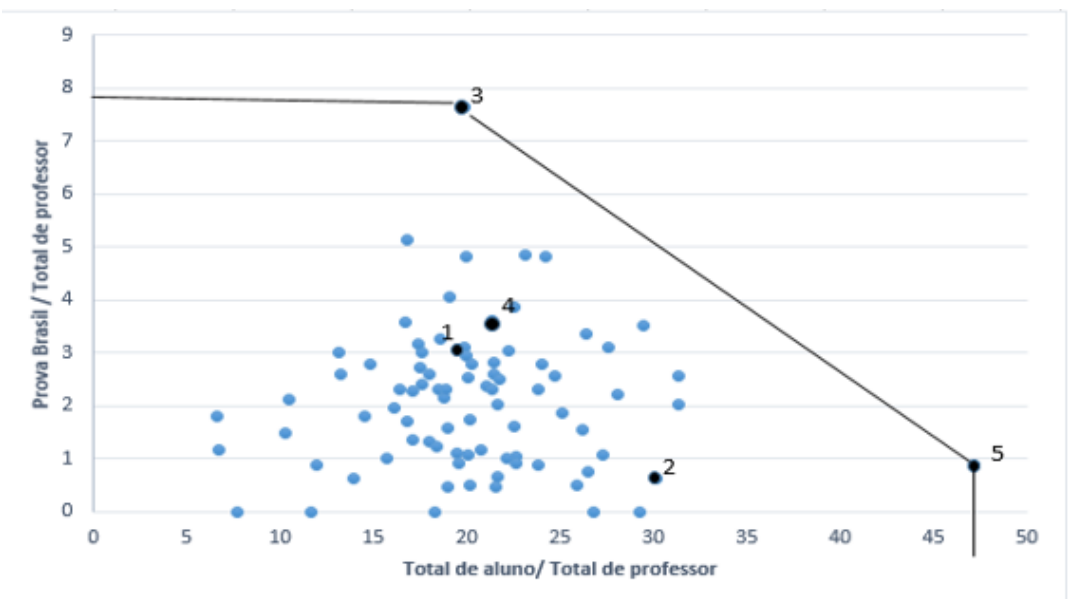

Figura 4.3: DEA 2, Conglomerado 1, 5 ano.

Para exemplificar a construção destas metas, analisaram-se os resultados obtidos pela escola (ineficiente) EC 209 Sul. Ela possui medida de eficiência de 0,78 e tem a Medida DEA igual a 1,28 indicando que pode aumentar proporcionalmente todos os resultados em $28 \%$ sem acréscimo dos recursos. Isto gera uma possibilidade de "aumento proporcional" da produção que chamou-se "meta proporcional". Esta projeção radial (proporcional) na direção da fronteira gerou folga na variável número de alunos indicando possibilidade de expansão da escola mantido o número de professores. Esta expansão, porém, depende de variáveis não consideradas neste trabalho (demanda, por exemplo). Agregando-se as folgas à meta proporcional, obtém-se a meta global que consiste no ponto da fronteira de eficiência no qual a EC 209 Sul foi projetada e que é definido pelas suas referências. A Figura 4.4 mostra os valores observados na EC 209 Sul e as metas projetadas pelo modelo DEA2.

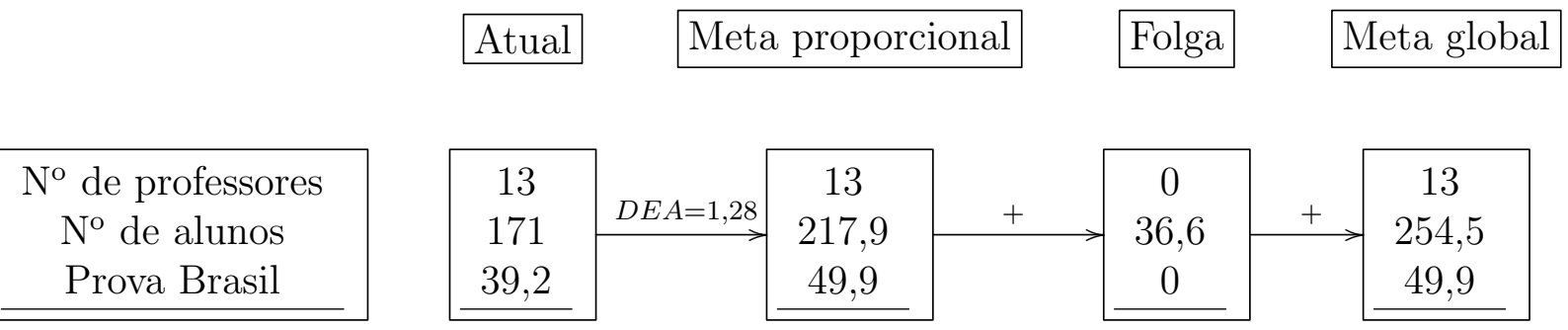

Figura 4.4: EC 209 Sul ineficiente para atingir a eficiência.

A escola EC 209 Sul tem como referências as escolas EC 106 NORTE e EC KANEGAE e a sua meta global é dada por:

$$
\text { EC } 209 \text { Sul }_{0}^{*}=0,64 E C 106 \text { NORTE +0,36 EC KANEGAE }
$$

Esta meta global constitui uma escola virtual e a trajetória entre os valores atuais da $E C 209 S u l_{0}^{*}$ e sua meta global identificou ações que conduzem a aumento da 
produtividade. As Tabelas B.4 e B.6 do Apêndice apresentam as metas proporcionais e globais das escolas ineficientes do $5^{\circ}$ ano do Conglomerado 1.

\subsection{2 $\quad 5^{\mathrm{o}}$ ano Conglomerado 2}

A aplicação do modelo DEA 2 as escolas do $5^{\circ}$ ano, Conglomerado 2 identificou oito escolas eficientes explicitadas na Tabela 4.4 e na Figura 4.5.

Tabela 4.4: DEA 2, $5^{\circ}$ ano, Conglomerado 2.

\begin{tabular}{l|c|c|c}
\hline Nome & Total de Professores & Total de alunos & Prova Brasil \\
\hline 1 - EC Brochado da Rocha & 4 & 56 & - \\
2 - EC 03 do Paranoá & 33 & 817 & 48,92 \\
3 - EC 05 do Núcleo Bandeirante & 13 & 230 & 50,36 \\
4 - EC Corrego do Barreiro & 5 & 126 & 35,30 \\
5 - CAIC Santa Maria & 54 & 1595 & 40,93 \\
6 - EC 604 de Samambaia & 22 & 1137 & 37,66 \\
7 - CEF 01 da Estrutural & 40 & 1864 & 31,03 \\
8 - CED Dona América Guimaraes & 29 & 2331 & - \\
\hline
\end{tabular}

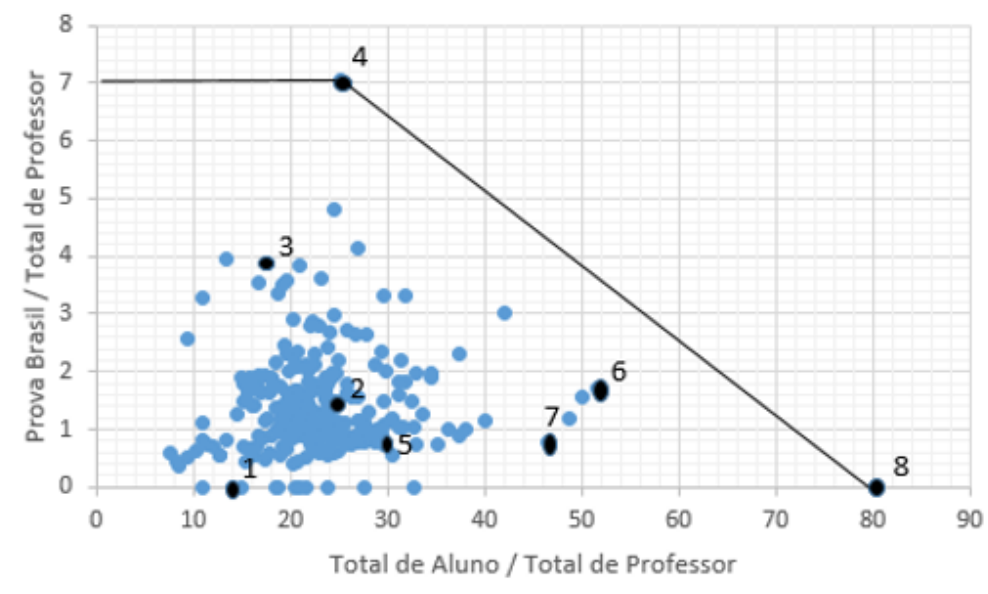

Figura 4.5: DEA 2, Conglomerado 2, $5^{\circ}$ ano.

A EC Brochado da Rocha é eficiente por ser a menor escola, a CED Dona América Guimaraes é eficiente por ser a maior escola e melhor relação Total de Alunos por Total de Professores, a EC 05 do Núcleo Bandeirante é eficiente por ter a maior nota da Prova Brasil e a EC Corrego do Barreiro é eficiente por ter maior relação entre Prova Brasil por Número de Professores. Enquanto as outras quatro escolas são eficientes porque são melhores que quaisquer combinações convexas entre essas escolas citadas. 


\subsection{3 $\quad 5^{\circ}$ ano comparando Conglomerado 1 e 2}

Para comparar as escolas dos Conglomerados 1 e 2, aplicou-se novamente o modelo DEA2 ao conjunto das escolas do Ensino Fundamental I, resultando dez escolas eficientes, duas delas do Conglomerado 1 e oito do Conglomerado 2. Desta forma, escolas do Conglomerado 2 (menos equipadas e em regiões de renda mais baixa) mantiveram-se eficientes mesmo quando comparadas com escolas do Conglomerado 1 (mais equipadas em regiões de renda mais alta). Essas escolas, mesmo em condições desfavoráveis, apresentam bom desempenho em relação ao número de alunos matriculados e seus resultados na Prova Brasil. Neste sentido, essas escolas constituem exemplos de boas práticas e as razões deste desempenho deve ser objeto de estudos futuros com um conjunto maior de variáveis. A Tabela 4.5 e a Figura 4.6 apresentam os resultados obtidos.

Tabela 4.5: Escolas Eficientes do $5^{\circ}$ ano, Conglomerado 1.

\begin{tabular}{l|l|c|c|c}
\hline Nome & $\begin{array}{l}\text { Total de } \\
\text { Professor }\end{array}$ & Total alunos & Prova Brasil & conglomerado \\
\hline $\begin{array}{l}\text { 1 - EC Brochado da Ro- } \\
\text { cha }\end{array}$ & 4 & 56 & - & 2 \\
2 - EC 03 do Paranoá & 33 & 817 & 48,92 & 2 \\
3 - EC 05 do Núcleo Ban- & 13 & 230 & 50,36 & 2 \\
deirante & & 126 & 35,30 & 2 \\
4 - EC Corrego do Bar- & 5 & 1595 & 40,93 & 2 \\
reiro & 54 & 1137 & 37,66 & 2 \\
5 - CAIC Santa Maria & 1864 & 31,03 & 2 \\
6 - EC 604 de Samambaia & 22 & 2331 & - & 2 \\
7 - CEF 01 da Estrutural & 40 & 332 & 52,29 & 1 \\
8 - CED Dona América & 29 & 119 & 45,80 & 1 \\
Guimaraes & 17 & 6 & & \\
9 - EC 106 Norte &
\end{tabular}




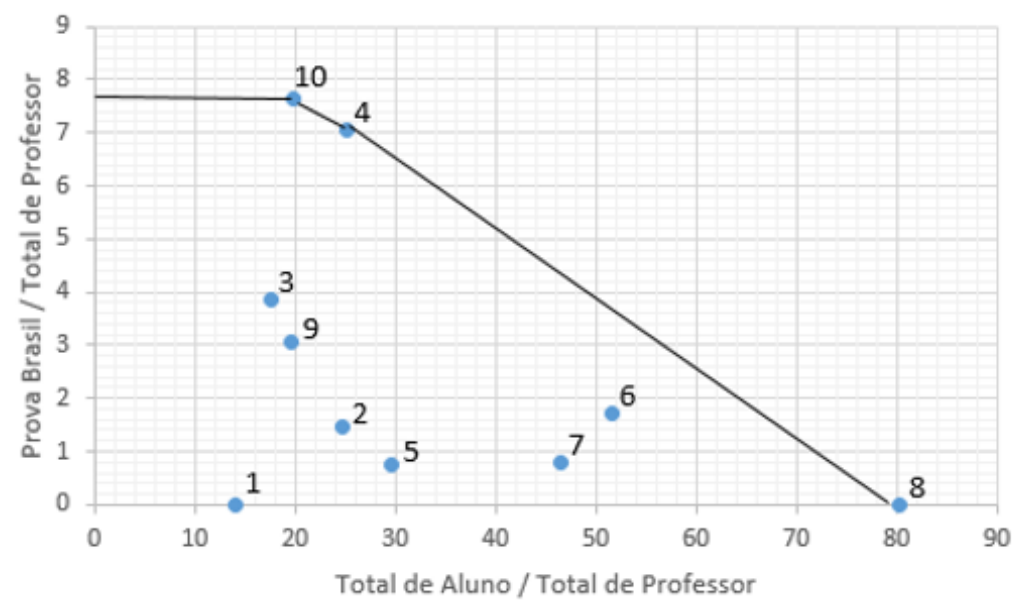

Figura 4.6: Escolas Eficientes.

\section{4 $\quad 9^{\circ}$ ano Conglomerado 1}

\subsubsection{Escolas Eficientes do $9^{\circ}$ ano, Conglomerado 1}

Aplicando-se o modelo DEA2 às escolas do $9^{\circ}$ ano Conglomerados 1 obtiveramse sete escolas eficientes conforme a Tabela 4.6 e a Figura 4.7.

Tabela 4.6: Escolas Eficientes do $9^{\circ}$ ano, Conglomerado 1.

\begin{tabular}{l|c|c|c}
\hline Nome & Total de Professores & Total alunos & Prova Brasil \\
\hline 1 - CEF 01 de Brasília & 17 & 446 & 55,40 \\
2 - CEF 04 de Brasília & 20 & 425 & 61,00 \\
3 - CEF Polivalente & 40 & 1099 & 56,82 \\
4 - CED 11 de Ceilândia & 68 & 2071 & 48,65 \\
5 - CED 104 do Recanto das & 37 & 1318 & 41,71 \\
Emas & & & \\
6 - CEF Bonsucesso & 15 & 320 & 59,62 \\
7 - CED Stella dos Cherubins & 50 & 1756 & 52,68 \\
Guimaraes Trois & & & \\
\hline
\end{tabular}

A Escola CEF 04 de Brasília é eficiente por ter maior nota da Prova Brasil. A CED 11 de Ceilândia é eficiente por ser a maior escola e não poder ser descrita como combinação convexa das demais, enquanto a CED 104 do Recanto das Emas é eficiente porque domina a relação Número de Alunos por Professores. A CEF Bonsucesso domina a relação Prova Brasil por Total de Professores. As demais duas escolas são eficientes em função da adoção de retornos variáveis à escala reduzindo a região viável às combinações convexas dos planos de operações observados. 


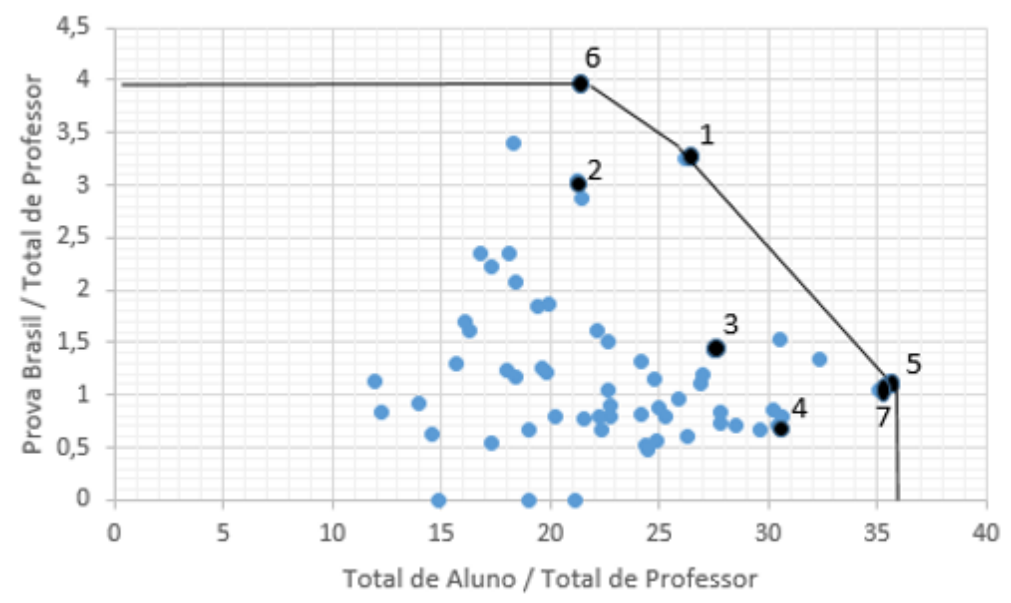

Figura 4.7: DEA 2, 9 ano, Conglomerado 1.

\subsection{2 $\quad 9^{\circ}$ ano, Conglomerado 2}

Aplicando-se o modelo DEA2 às escolas do $9^{\circ}$ ano conglomerados 2 obtiveramse 10 escolas eficientes conforme a Tabela 4.7 e a Figura 4.8.

Tabela 4.7: Escolas Eficientes $9^{\circ}$ ano, Conglomerado 2.

\begin{tabular}{l|c|c|c}
\hline Nome & Total de Professores & Total alunos & Prova Brasil \\
\hline 1 - CEF Ponte Alta do Norte & 13 & 294 & 52,63 \\
2 - CEF 08 de Taguatinga & 33 & 809 & 56,51 \\
3 - CEF 10 de Taguatinga & 18 & 869 & 44,56 \\
4 - CEF Jardim II & 12 & 247 & - \\
5 - CEF 01 do Núcleo Bandei- & 55 & 1021 & 56,60 \\
rante & & & \\
6 - CEF 25 de Ceilândia & 90 & 2415 & 53,21 \\
7 - CED 07 de Ceilândia & 93 & 1828 & 41,69 \\
8 - CEF 03 do Paranoá & 37 & 2189 & 47,51 \\
9 - CEF São Bartolomeu & 43 & 2331 & 39,70 \\
10 - CED Dona América Gui- & 54 & & \\
maraes & & & \\
\hline
\end{tabular}

A Escola CEF 08 de Taguatinga é eficiente porque possui a maior nota na Prova Brasil, a CEF JARDIM II é eficiente por ser a menor escola, a CED 07 DE Ceilândia é eficiente por ser a maior escola, CEF São Bartolomeu é eficiente porque domina a relação número de alunos por número de professor e a CEF Ponte Alta do Norte porque domina a relação Prova Brasil por número de professor. Enquanto as outras quatro escolas são eficientes pois são as melhores em combinação linear entre essas escolas. 


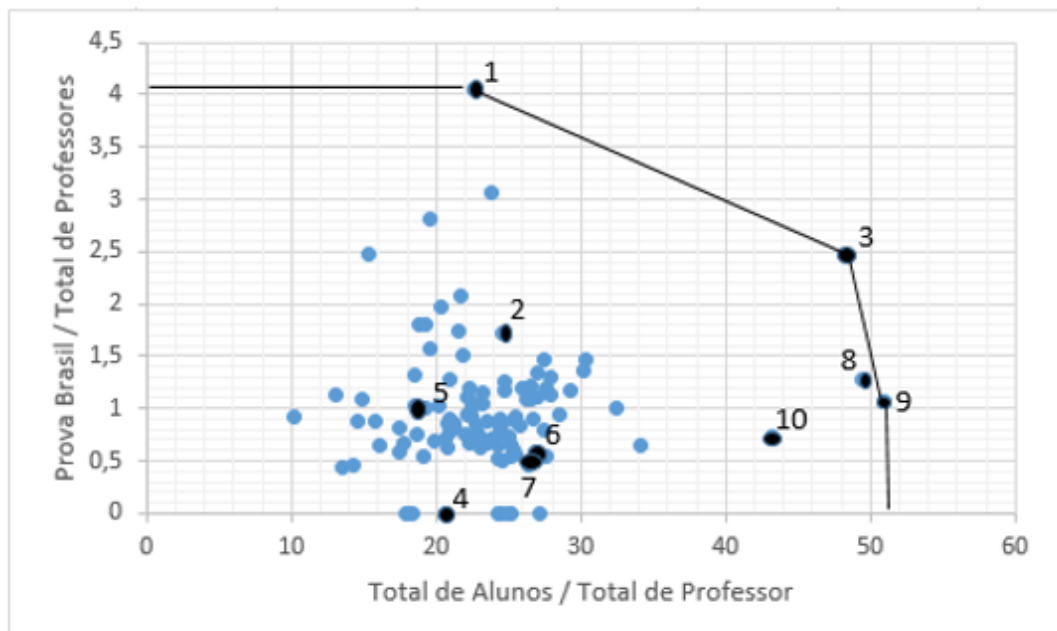

Figura 4.8: Escolas Eficientes $9^{\circ}$ ano, Conglomerado 2.

\subsubsection{Comparando as Escolas Eficientes do Conglomerado 1 e 2}

Aplicando-se o modelo DEA2 às escolas do $9^{\circ}$ ano, Conglomerados 1 e 2 obtiveram-se onze escolas eficientes conforme a Tabela 4.8 e a Figura 4.9 .

Tabela 4.8: Escolas Eficientes entre Conglomerado 1 e 2.

\begin{tabular}{l|l|c|c|c}
\hline Nome & $\begin{array}{l}\text { Total de } \\
\text { Professores }\end{array}$ & Total de alunos & Prova Brasil & conglomerado \\
\hline 1 - CEF 04 de Brasília & 20 & 425 & 61,00 & 1 \\
2 - CEF Bonsucesso & 15 & 320 & 59,62 & 1 \\
3 - CED Stella dos Che- & 50 & 1756 & 52,68 & 1 \\
rubins Guimaraes Trois & & & & \\
4 - CEF Ponte Alta do & 13 & 294 & 52,63 & 2 \\
Norte & & 869 & 44,56 & 2 \\
5 - CEF 10 de Taguatinga & 18 & 247 & - & 2 \\
6 - CEF Jardim II & 12 & 2415 & 53,21 & 2 \\
7 - CEF 25 de Ceilândia & 90 & 2449 & 41,69 & 2 \\
8 - CED 07 de Ceilândia & 93 & 1828 & 47,51 & 2 \\
9 - CEF 03 do Paranoá & 37 & 2189 & 45,70 & 2 \\
10 - CEF São Bartolomeu & 43 & 2331 & 39,53 & 2 \\
11 - CED Dona América & 54 & & & \\
Guimaraes & & & & \\
\hline
\end{tabular}

A Escola CEF Bonsucesso é eficiente por ter a maior a relação Prova Brasil por número de professor, a CED 07 de Ceilândia é eficiente por ser a maior escola, a CEF Jardim II é eficiente por ser a menor escola, a CEF 301 do Recanto das Emas é eficiente por ter a melhor relação número de alunos por número de professor e CEF 04 


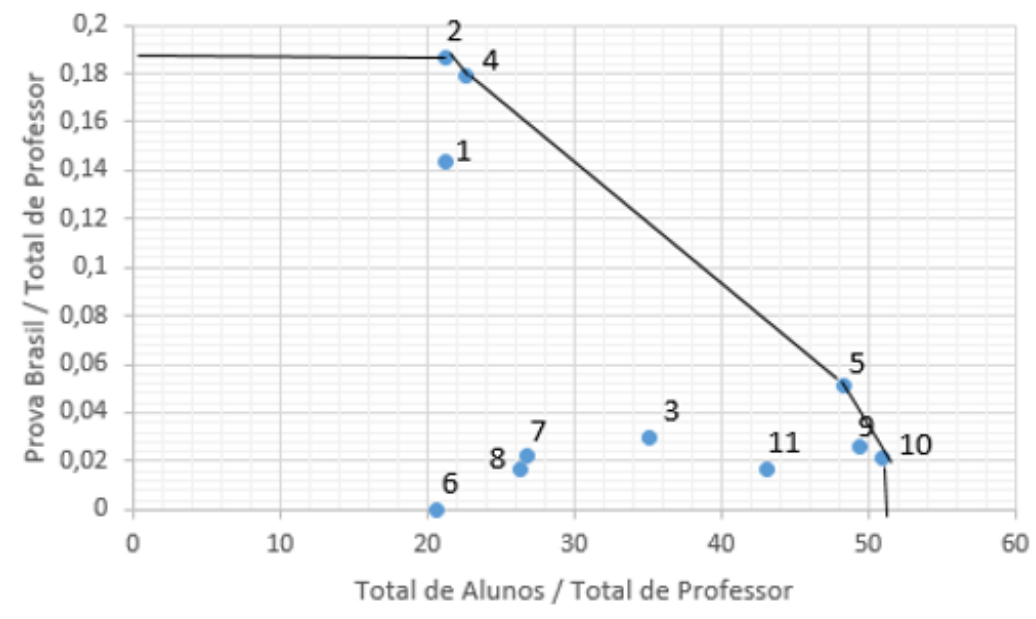

Figura 4.9: Escolas Eficientes do Conglomerado 1 e 2.

de Brasília possui a maior nota da Prova Brasil. Enquanto as outras seis escolas são eficientes por serem uma melhor combinação linear entre as outras escolas.

\subsection{Análise do DEA}

Em função das diferenças entre os grupos identificada na Análise de Conglomerados, aplicou-se a Análise Envoltória de Dados dentro de cada grupo em cada um dos segmentos (Ensino Fundamental I e Ensino Fundamental II), com a mesma função de desempenho que considerou o número total de professores como insumo e o número de alunos matriculados e os resultados da Prova Brasil como produtos. Resultaram quatro aplicações de DEA que permitiram identificar escolas eficientes em cada subgrupo considerado e estabelecer ações de melhoria naquelas consideradas ineficientes.

Assim, tanto nas escolas do Ensino Fundamental I quanto do Ensino Fundamental II, aplicou-se DEA em escolas com condições semelhantes de infraestrutura e renda local, permitindo maior comparabilidade e aceitação das referências.

Após analisar as escolas dentro de cada conglomerado, realizou-se uma aplicação de DEA agregando os conglomerados, tanto no Ensino Fundamental I, quanto no Ensino Fundamental II. Observou-se, em ambos os segmentos, que algumas escolas do conglomerado com piores condições de infraestrutura e renda se mantinham eficientes mesmo quando comparada com o universo das escolas. Essas escolas apresentam bom desempenho mesmo em condições desfavoráveis de infraestrutura e renda, qualificando-se, assim, como referências importantes do sistema de ensino, cujos processos de ensino-aprendizagem devem ser estudados em função do bom desempenho tanto quantitativo quando qualitativo alcançados. 


\section{Capítulo 5}

\section{Considerações Finais}

Esta pesquisa iniciou-se pela caracterização das escolas do Ensino Fundamental do sistema de ensino do DF. Foi observada a existência de escolas em condições diferentes tanto em relação a infraestrutura quanto ao ambiente socioeconômico no qual se insere.

Em um primeiro momento separou-se as escolas do Ensino Fundamental I ( $1^{\circ}$ ao $5^{\circ}$ ano $)$ e do Ensino Fundamental II ( $6^{\circ}$ ao $9^{\circ}$ ano). Dentro de cada um destes segmentos aplicou-se Análise de Conglomerados a partir de indicadores de infraestrutura da escola e renda da região em que se insere. Destacaram-se, em ambos os segmentos dois grupos de escolas. O primeiro caracterizado por instituições melhores equipadas em regiões de renda mais alta. O segundo por escolas em piores condições de infraestrutura em regiões de renda mais baixa.

Pela análise de conglomerados tem-se que as escolas mais equipadas possuem melhores notas na Prova Brasil e, com isto, há necessidade em investir mais em instalações, televisão por sala de aula e acesso a computador. Da análise pode-se inferir que quando a escola tem uma boa infraestrutura, isto motiva os docentes e os alunos. Nota-se que nessas escolas os professores e alunos possuem condições de fazer trabalhos diferenciados. Por exemplo, com uma boa biblioteca esse grupo passará a ler mais tendo como consequência um rendimento melhor na Prova Brasil. Além disso, com o acesso à internet sob a orientação do professor, os alunos podem consultar sites que podem ajudá-los a ter informações precisas, como vídeos aulas de "khan academy", "só matemática" entre outros.

Como a correlação linear entre a titulação do professor e a nota da Prova Brasil é baixa, há uma indicação de que os professores com maior formação não estão influenciando na nota da Prova Brasil. Pode-se deduzir que a estabilidade do professor acomoda e este não se motiva em preparar melhor as aulas. Com relação a esse motivo, sugere-se que o professor deva ter melhores salários em função do rendimento dos alunos. Além disso, sabe-se que quanto melhor a formação do professor ele também 
estará mais preparado em relação a metodologias de ensino-aprendizagem e domínio do conteúdo. Porém, não temos os dados referentes a quantidade e a qualidade dos cursos de formação que os professores obtiveram. Por isso, o professor deveria fazer cursos constantemente para que ele se mantenha atualizado. No caso do Distrito Federal, o professor tem até 10 horas semanais de coordenação que é utilizada para preparar aula, planejar projetos da escola e corrigir as provas, trabalhos, deveres de casa, lista de exercício. Por isto, deveria ter curso sobre o conteúdo que ele irá ministrar para forçar o professor a ficar atualizado sobre o assunto. É papel de um docente mostrar a importância da Prova Brasil e o que a nota obtida pode mostrar acerca do nível de desempenho do aluno em leitura e resolução de problemas. Com esta informação o próprio aluno poderia revisar os conteúdos descritos nas Tabela A.1 do anexo. Sabendo disso, os alunos poderiam ter um maior empenho em fazer essa avaliação. A falta de feedback do INEP para o aluno, pois os avaliados não possuem o resultado individual, pode indicar que estas pessoas que fazem a prova não enxergam a importância da Prova Brasil.

Em função das diferenças entre os grupos identificada na Análise de Conglomerados, aplicou-se a Análise Envoltória de Dados dentro de cada grupo em cada um dos segmentos (Ensino Fundamental I e Ensino Fundamental II), com a mesma função de desempenho que considerou o número total de professores como insumo e o número de alunos matriculados e os resultados da Prova Brasil como produtos. Resultaram quatro aplicações de DEA que permitiram identificar escolas eficientes em cada subgrupo considerado e estabelecer ações de melhoria naquelas consideradas ineficientes.

Assim, tanto nas escolas do Ensino Fundamental I quanto do Ensino Fundamental II, aplicou-se DEA em escolas com condições semelhantes de infraestrutura e renda local, permitindo maior comparabilidade e aceitação das referências.

Após analisar as escolas dentro de cada conglomerado, realizou-se uma aplicação de DEA agregando os conglomerados, tanto no Ensino Fundamental I, quanto no Ensino Fundamental II. Observou-se, em ambos os segmentos, que algumas escolas do conglomerado com piores condições de infraestrutura e renda se mantinham eficientes mesmo quando comparada com o universo das escolas. Essas escolas apresentam bom desempenho mesmo em condições desfavoráveis de infraestrutura e renda, qualificando-se, assim, como referências importantes do sistema de ensino, cujos processos de ensino-aprendizagem devem ser estudados em função do bom desempenho tanto quantitativo quanto qualitativo alcançados.

A DEA sugere ações que tornam estas escolas eficientes como referência e conduzem as demais a melhorias de desempenho.

A taxa de aprovação dos estudantes não se mostrou adequada na construção dos modelos DEA, uma vez que apresenta baixa variância, não diferenciando as escolas caracterizando-se mais como uma política de ensino do que como uma medida do 
desempenho do aluno. Pode-se deduzir que a maioria dos sistemas escolares ainda mantém amplamente a ficção segundo a qual todas as crianças de seis anos que entram na primeira série da escola obrigatória estariam igualmente desejosas e seriam capazes de aprender a ler e a escrever em um ano. Sabe que isso é falso, o que não impede que tal ficção permaneça no princípio da estrutura escolar, do tratamento das faixas etárias e da distribuição do programa em graus anuais. No início da escolaridade obrigatória, as diferenças de idades são as únicas que a escola aceita levar em conta. Para afrontar a formidável diversidade dos ritmos de desenvolvimento, desejou-se ignorar ou deixar por conta das dispensas por idade o fato de que, aos seis anos, certos alunos possam manifestar um nível de desenvolvimento que outros só atingirão aos sete ou oito, ao passo que outros já o haviam atingido aos quatro ou cinco. Um atraso de desenvolvimento só é considerado quando tiver originado dificuldades graves, até mesmo um fracasso. A repetição da primeira série de escolaridade obrigatória, que pretende aumentar a homogeneidade dos alunos que passam para o ano seguinte, está muito fortemente ligada à classe social, que é, assim, indiretamente considerada, por uma medida de diferenciação grosseira e cujos efeitos são duvidosos. Em [12], tem-se mais detalhes.

Apesar do pequeno número de variáveis disponíveis e da heterogeneidade das escolas, a metodologia proposta mostrou-se eficaz na descrição do sistema de ensino, na identificação dos melhores desempenhos e na construção de estratégias que conduzam as escolas ineficientes a melhorias. 


\section{Referências Bibliográficas}

[1] Anderberg, M. R. (1973), Cluster Analysis for Applications, New York: Academic Press. 18

[2] BANKER, R.D.; CHARNES A.; COOPER, W.W. Some models for estimation technical and scale inefficiencies in Data Envelopment Analysis. Management Science, 30 (9):1078-1092, 1984. 11

[3] BELLONI, J. A. Uma metodologia de avaliação da eficiência produtiva de universidades federais brasileiras. 2000. Tese (Doutorado em Engenharia de Produção) - Universidade Federal de Santa Catarina, Florianópolis, 2000. 6, 7

[4] BUSSAB, W. de O.; MIAZAKI, S. E.; ANDRADE, D. F.Introdução à análise de agrupamento. In: IX SIMPÓSIO BRASILEIRO DE PROBABILIDADE E ESTATÍSITICA. São Paulo: IME-USP, 1990. 18

[5] CHARnES, A.; COOPER, W. W.; RHODES, E. Measuring the efficiency of decision making units. European Journal of Operational Research, 2 (6) :429444, 1978. 9

[6] CHARNES,A. e COOPER, W.W. Programming with linear fractional functionals. Naval Res. Logist. Quart., 9, 181-185, 1962. 7

[7] CHARneS, A.; COOPER, W. W.; LEvin, A. Y.; SEIFORD, L. Data Envolopment Analysis: theory, methodology and applications. USA, Kluwer Academic Publishers, 1994. 5

[8] JOHnSON, Richard A. and Wichern, Dean W. Applied Multivarieate Statistica Analysis. Prentice Hall, Pearson. 20

[9] Estellita Lins, M.P. \& Angulo Meza, L. (2000).Análise Envoltória de Dados e perspectivas de integração no ambiente de Apoio à Decisão. Editora da COPPE/UFRJ, Rio de Janeiro. 5 
[10] FÄRE, R.; GROSSKOPF, S.; LOVELL, C.A.K. Production frontiers. New York, Cambridge University, 1994.

[11] NORMAn, M. e STOKER, B. Data Envelopment Analysis: The Assesment of 14

[12] PERRENOUD, Phillipe. Avaliação: da excelência à regularização das aprendizagens: entre duas lógicas. Porto Alegre, Artmed, 1998. 55

[13] RHODES, E.L. Data Envelopment Analysis and approaches for measuring the efficiency of decision making units with an application to program follow-through in U.S. education. Ph.D. Dissertation, Carnegie Mellon Unversity, 1978. 5

[14] Romesburg,H.C., 1984. Cluster Analysis for Researchers. Belmont, Calif.: Lifetime Learning Publications. 18

[15] www.inep.gov.br; último acesso em 30/03/2016. 2, 3

[16] http://dados.gov.br/dataset/taxas-de-rendimento-escolar-na-educacao-basica; último acesso em 30/03/2016. 29 


\section{Apêndice A}

\section{Apêndice}

Tabela A.1: Nível de Desempenho dos alunos segundo a Prova Brasil.

Português

\begin{tabular}{|c|c|}
\hline $\begin{array}{l}\text { Níveis de } \\
\text { Desempenho } \\
\text { dos alunos } \\
\text { em Leitura }\end{array}$ & O que os alunos conseguem fazer nesse nível \\
\hline $\begin{array}{l}\text { Nível } \\
0 \\
\text { abaixo } \\
\text { de } 125\end{array}$ & $\begin{array}{l}\text { A Prova Brasil não utilizou itens que avaliam as habilidades abaixo deste } \\
\text { nível. } \\
\text { Os alunos localizados abaixo do nível } 125 \text { requerem atenção especial, pois, } \\
\text { não demonstram habilidades muito elementares como as de: } \\
\text { Localizar informação (exemplo: o personagem principal, local e tempo da } \\
\text { narrativa); } \\
\text { Identificar o efeito de sentido decorrente da utilização de recursos gráficos } \\
\text { (exemplo: letras maiúsculas chamando a atenção em um cartaz); e } \\
\text { Identificar o tema, em um texto simples e curto. }\end{array}$ \\
\hline $\begin{array}{ll}\text { Nível } & 1 \\
- & 125 \text { a } \\
150\end{array}$ & $\begin{array}{l}\text { Os alunos do } 5^{\mathrm{o}} \text { e } 9^{\mathrm{o}} \text { anos }\left(4^{\mathrm{a}} \text {. e } 8^{\mathrm{a}} \text {. séries): }\right. \\
\text { Localizam informações explícitas em textos narrativos curtos, informativos } \\
\text { e anúncios; } \\
\text { Identificam o tema de um texto; } \\
\text { Localizam elementos como o personagem principal; } \\
\text { Estabelecem relação entre partes do texto: } \\
\text { personagem e ação; } \\
\text { ação e tempo; } \\
\text { ação e lugar. }\end{array}$ \\
\hline
\end{tabular}




\begin{tabular}{|c|c|}
\hline & O que os alunos conseguem fazer nesse nível \\
\hline $\begin{array}{l}\text { Nível } 2 \\
-150 \text { a } \\
175\end{array}$ & $\begin{array}{l}\text { Este nível é constituído por narrativas mais complexas e incorporam outros } \\
\text { gêneros textuais, por isto, ainda que algumas habilidades aqui apontadas } \\
\text { já estejam listadas anteriormente, elas se mostraram mais difíceis neste in- } \\
\text { tervalo. } \\
\text { Além das habilidades anteriormente citadas, os alunos do } 5^{\circ} \text { e } 9^{\circ} \text { anos }\left(4^{\mathrm{a}} \text {. }\right. \\
\text { e } 8^{\mathrm{a}} \text {. séries): } \\
\text { Localizam informação explícita. Exemplo: identificando, dentre vários per- } \\
\text { sonagens, o principal, e, em situações mais complexas, a partir de seleção e } \\
\text { comparação de partes do texto; } \\
\text { Identificam o tema de um texto; } \\
\text { Inferem informação em texto verbal (características do personagem) e não } \\
\text { verbal (tirinha); } \\
\text { interpretam pequenas matérias de jornal, trechos de enciclopédia, poemas } \\
\text { longos e prosa poética; } \\
\text { identificam o conflito gerador e finalidade do texto }\end{array}$ \\
\hline $\begin{array}{l}\text { Nível } 3 \\
-175 \text { a } \\
200\end{array}$ & $\begin{array}{l}\text { Além das habilidades anteriormente citadas, os alunos do } 5^{\circ} \text { e } 9^{\circ} \text { anos }\left(4^{\mathrm{a}} \text {. }\right. \\
\text { e } 8^{\mathrm{a}} \text {. séries): } \\
\text { interpretam, a partir de inferência, texto não-verbal (tirinha) de maior com- } \\
\text { plexidade temática; } \\
\text { identificam o tema a partir de características que tratam de sentimentos do } \\
\text { personagem principal; } \\
\text { reconhecem elementos que compõem uma narrativa com temática e voca- } \\
\text { bulário complexos. }\end{array}$ \\
\hline $\begin{array}{l}\text { Nível } 4 \\
-200 \text { a } \\
225\end{array}$ & $\begin{array}{l}\text { Além de demonstrar todas as habilidades anteriores a partir de anedotas, } \\
\text { fábulas e textos com linguagem gráfica pouco usual, narrativos complexos, } \\
\text { poéticos, informativos longos ou com informação científica, o s alunos do } 5^{\circ} \\
\text { e do } 9^{\circ} \text { anos }\left(4^{\mathrm{a}} \text {. E } 8^{\mathrm{a}} \text {. séries): }\right. \\
\text { identificam, dentre os elementos da narrativa que contém discurso direto, o } \\
\text { narrador observador; } \\
\text { selecionam entre informações explícitas e implícitas as correspondentes a } \\
\text { um personagem; } \\
\text { localizam informação em texto informativo, com estrutura e vocabulário } \\
\text { complexos; } \\
\text { inferem a informação que provoca efeito de humor no texto; }\end{array}$ \\
\hline
\end{tabular}




\begin{tabular}{|c|c|}
\hline & O que os alunos conseguem fazer nesse nível \\
\hline $\begin{array}{l}\text { Nível } \\
4-200 \\
\text { a } \quad 225 \\
\text { (cont.) }\end{array}$ & $\begin{array}{l}\text { interpretam texto verbal, cujo significado é construído com o apoio de ima- } \\
\text { gens, inferindo informação; } \\
\text { identificam o significado de uma expressão em texto informativo; } \\
\text { inferem o sentido de uma expressão metafórica e o efeito de sentido de uma } \\
\text { onomatopeia; } \\
\text { interpretam história em quadrinho a partir de inferências sobre a fala da } \\
\text { personagem, identificando o desfecho do conflito; } \\
\text { estabelecem relações entre as partes de um texto, identificando substituições } \\
\text { pronominais que contribuem para a coesão do texto. }\end{array}$ \\
\hline $\begin{array}{l}\text { Nível } 5 \\
-225 \text { a } \\
250\end{array}$ & $\begin{array}{l}\text { Além das habilidades anteriores, os alunos do } 5^{\circ} \text { e } 9^{\circ} \text { anos }\left(4^{\mathrm{a}} \text {. e } 8^{\mathrm{a}} \text {. séries): }\right. \\
\text { identificam o efeito de sentido decorrente do uso da pontuação (reticências); } \\
\text { inferem a finalidade do texto; } \\
\text { distinguem um fato da opinião relativa a este fato, numa narrativa com } \\
\text { narrador personagem; } \\
\text { distinguem o sentido metafórico do literal de uma expressão; } \\
\text { reconhecem efeitos de ironia ou humor em textos variados; } \\
\text { identificam a relação lógico-discursiva marcada por locução adverbial ou } \\
\text { conjunção comparativa; } \\
\text { interpretam texto com apoio de material gráfico; } \\
\text { localizam a informação principal. } \\
\text { Os alunos do } 9^{\circ} \text { ano, neste nível, ainda: } \\
\text { inferem o sentido de uma palavra ou expressão; } \\
\text { estabelecem relação causa/consequência entre partes e elementos do texto; } \\
\text { identificam o tema de textos narrativos, argumentativos e poéticos de } \\
\text { conteúdo complexo; } \\
\text { identificam a tese e os argumentos que a defendem em textos argumentati- } \\
\text { vos; } \\
\text { reconhecem o efeito de sentido decorrente da escolha de uma determinada } \\
\text { palavra ou expressão. }\end{array}$ \\
\hline $\begin{array}{l}\text { Nível } 6 \\
-250 \text { a } \\
275\end{array}$ & $\begin{array}{l}\text { Utilizando como base a variedade textual já descrita, neste nível os alunos } \\
\text { do } 5^{\circ} \text { e do } 9^{\circ} \text { anos }\left(4^{\mathrm{a}} \text {. e } 8^{\mathrm{a}} \text {. séries }\right) \text {, além de demonstrarem as habilidades } \\
\text { anteriores: } \\
\text { localizam características do personagem em texto poético; } \\
\text { distinguem um fato da opinião relativa a este fato; } \\
\text { identificam uma definição em texto expositivo; }\end{array}$ \\
\hline
\end{tabular}




\begin{tabular}{|c|c|}
\hline & O que os alunos conseguem fazer nesse nível \\
\hline $\begin{array}{l}\text { Nível } \\
6-250 \\
\text { a } \quad 275 \\
\text { (cont.) }\end{array}$ & $\begin{array}{l}\text { estabelecem relação causa/consequência entre partes e elementos do texto; } \\
\text { inferem a finalidade do texto a partir do suporte; } \\
\text { inferem o sentido de uma palavra ou expressão; } \\
\text { identificam a finalidade do texto; } \\
\text { identificam o assunto em um poema; } \\
\text { comparam textos que tratam do mesmo tema, reconhecendo diferentes for- } \\
\text { mas de tratar a informação; } \\
\text { interpretam texto a partir de material gráfico diverso (gráficos, tabelas, } \\
\text { etc); } \\
\text { estabelecem relações entre as partes de um texto, identificando substituições } \\
\text { pronominais que contribuem para a coesão do texto. } \\
\text { Os alunos do } 9^{\circ} \text { ano ( } 8^{\text {a }} \text {. série) ainda: } \\
\text { estabelecem relações entre partes de um texto, reconhecendo o sentido de } \\
\text { uma } \\
\text { expressão que contribui para a continuidade do texto; } \\
\text { estabelecem relações lógico-discursivas presentes no texto, marcadas por } \\
\text { conjunções, advérbios, etc; } \\
\text { reconhecem o efeito de sentido decorrente da exploração de recursos } \\
\text { ortográficos e/ou morfossintáticos; } \\
\text { identificam o conflito gerador do enredo e os elementos que constroem a } \\
\text { narrativa; } \\
\text { identificam a tese e o argumento que defendem em texto com a linguagem } \\
\text { informal; } \\
\text { inferem informação a partir de um julgamento em textos narrativos longos; } \\
\text { inferem efeitos de ironia ou humor em narrativas curtas; } \\
\text { inferem o sentido de uma expressão em texto narrativo longo e de voca- } \\
\text { bulário complexo }\end{array}$ \\
\hline $\begin{array}{l}\text { Nivel } 7 \\
-275 \text { a } \\
300\end{array}$ & $\begin{array}{l}\text { Além de demonstrar as habilidades dos níveis anteriores, no } 5^{\circ} \text { e no } 9^{\circ} \\
\text { anos }\left(4^{\mathrm{a}} \text {. e } 8^{\mathrm{a}} \text {. séries), os alunos: }\right. \\
\text { inferem informação em texto narrativo longo; } \\
\text { identificam relação lógico-discursiva marcada por locução adverbial de lu- } \\
\text { gar, advérbio de tempo ou termos comparativos em textos narrativos longos, } \\
\text { com temática e vocabulário complexos. } \\
\text { Os alunos do } 9^{\mathrm{o}} \text { ano }\left(8^{\mathrm{a}} \text {. série): }\right.\end{array}$ \\
\hline
\end{tabular}




\begin{tabular}{|c|c|}
\hline & O que os alunos conseguem fazer nesse nível \\
\hline $\begin{array}{l}\text { Nível } \\
7-275 \\
\text { a } \quad 300 \\
\text { (cont.) }\end{array}$ & $\begin{array}{l}\text { inferem informações implícitas em textos poéticos subjetivos, textos argu- } \\
\text { mentativos com intenção irônica, fragmento de narrativa literária clássica, } \\
\text { versão modernizada de fábula e histórias em quadrinhos; } \\
\text { reconhecem o efeito de sentido decorrente da utilização de uma determinada } \\
\text { expressão; } \\
\text { estabelecem relação causa/conseqüência entre partes e elementos do texto; } \\
\text { reconhecem posições distintas entre duas ou mais opiniões relativas ao } \\
\text { mesmo fato ou tema; } \\
\text { comparam textos que tratam do mesmo tema, reconhecendo diferentes for- } \\
\text { mas de tratar a informação. }\end{array}$ \\
\hline $\begin{array}{ll}\text { Nível } & 8 \\
-300 & \text { a } \\
325 & \end{array}$ & $\begin{array}{l}\text { Além de demonstrar as habilidades dos níveis anteriores, no } 5^{\circ} \text { e no } 9^{\circ} \text { anos } \\
\left(4^{\mathrm{a}} . \text { e } 8^{\mathrm{a}} \text {. séries), os alunos: identificam o assunto do texto em narrativas }\right. \\
\text { longas com vocabulário complexo; } \\
\text { inferem informações em fábulas. } \\
\text { Os alunos do } 9^{\circ} \text { ano ( } 8^{\mathrm{a}} \text {. série): } \\
\text { inferem o tema de texto poético; } \\
\text { inferem a finalidade de texto informativo; } \\
\text { identificam a opinião do autor em texto informativo com vocabulário com- } \\
\text { plexo; } \\
\text { diferenciam as partes principais das secundárias de um texto; } \\
\text { interpretam tabela a partir da comparação entre informações; } \\
\text { inferem o sentimento do personagem em história em quadrinhos; } \\
\text { estabelecem relação entre a tese e os argumentos oferecidos para sustentá- } \\
\text { la; } \\
\text { identificam a tese de um texto argumentativo; } \\
\text { identificam o conflito gerador do enredo; } \\
\text { reconhecem o efeito de sentido decorrente do uso da pontuação e de outras } \\
\text { notações. }\end{array}$ \\
\hline $\begin{array}{l}\text { Nível } 9 \\
-325 \text { a } \\
350\end{array}$ & $\begin{array}{l}\text { Além das habilidades descritas anteriormente, os alunos da } 9^{\circ} \text { ano }\left(8^{\mathrm{a}} \text {. série }\right) \\
\text { localizados neste nível demonstram habilidades de leitura que envolvem } \\
\text { compreensão global de texto; } \\
\text { avaliação e estabelecimento de relações entre textos e partes de textos mais } \\
\text { longos e com vocabulário complexos; inferem informações em diversos con- } \\
\text { textos; } \\
\text { e começam a ler com compreensão textos da literatura clássica. }\end{array}$ \\
\hline
\end{tabular}


Matemática

\begin{tabular}{|c|c|}
\hline $\begin{array}{l}\text { Níveis de } \\
\text { Desempe- } \\
\text { nho dos } \\
\text { alunos em } \\
\text { Matemática }\end{array}$ & O que os alunos conseguem fazer nesse nível e exemplos de competência \\
\hline $\begin{array}{l}\text { Nível } \\
0 \\
\text { abaixo } \\
\text { de } 125\end{array}$ & $\begin{array}{l}\text { A Prova Brasil não utilizou itens que avaliam as habilidades abaixo do nível } \\
125 . \\
\text { Os alunos localizados abaixo deste nível requerem atenção especial, pois } \\
\text { ainda não demonstraram ter desenvolvido as habilidades mais simples apre- } \\
\text { sentadas para os alunos do } 5^{\circ} \text { ano como exemplo: } \\
\text { somar e subtrair números decimais; } \\
\text { fazer adição com reserva; } \\
\text { multiplicar e dividir com dois algarismos; } \\
\text { trabalhar com frações. }\end{array}$ \\
\hline $\begin{array}{ll}\text { Nivel } & 1 \\
- & 125 \text { a } \\
150\end{array}$ & $\begin{array}{l}\text { Neste nível os alunos do } 5^{\circ} \text { e do } 9^{\mathrm{a}} \text { anos resolvem problemas de cálculo } \\
\text { de área com base na contagem das unidades de uma malha quadriculada } \\
\text { e, apoiados em representações gráficas, reconhecem a quarta parte de um } \\
\text { todo. }\end{array}$ \\
\hline $\begin{array}{l}\text { Nível } 2 \\
-150 \text { a } \\
175\end{array}$ & $\begin{array}{l}\text { Além das habilidades demonstradas no nível anterior, neste nível os alunos } \\
\text { do } 5^{\circ} \text { e } 9^{\circ} \text { anos são capazes de: } \\
\text { reconhecer o valor posicional dos algarismos em números naturais; } \\
\text { ler informações e dados apresentados em gráfico de coluna; } \\
\text { interpretar mapa que representa um itinerário. }\end{array}$ \\
\hline $\begin{array}{l}\text { Nível } 3 \\
-175 \text { a } \\
200\end{array}$ & $\begin{array}{l}\text { Além das habilidades demonstradas nos níveis anteriores, neste nível os alu- } \\
\text { nos do } 5^{\circ} \text { e } 9^{\circ} \text { anos: } \\
\text { calculam resultado de uma adição com números de três algarismos, com } \\
\text { apoio de material dourado planificado localizam informação em mapas de- } \\
\text { senhados em malha quadriculada; } \\
\text { reconhecem a escrita por extenso de números naturais e a sua composição } \\
\text { e decomposição em dezenas e unidades, considerando o seu valor posicional } \\
\text { na base decimal; } \\
\text { resolvem problemas relacionando diferentes unidades de uma mesma me- } \\
\text { dida para cálculo de intervalos (dias, semanas, horas e minutos) }\end{array}$ \\
\hline $\begin{array}{l}\text { Nível } 4 \\
-200 \text { a } \\
225\end{array}$ & $\begin{array}{l}\text { Além das habilidades descritas anteriormente, os alunos do } 5^{\circ} \text { e } 9^{\circ} \text { anos: } \\
\text { lêem informações e dados apresentados em tabela; } \\
\text { reconhecem a regra de formação de uma seqüência numérica e dão conti- } \\
\text { nuidade a ela; }\end{array}$ \\
\hline
\end{tabular}




\begin{tabular}{|c|c|}
\hline $\begin{array}{l}\text { Níveis de } \\
\text { Desempe- } \\
\text { nho dos } \\
\text { alunos em } \\
\text { Matemática } \\
\end{array}$ & O que os alunos conseguem fazer nesse nível e exemplos de competência \\
\hline $\begin{array}{l}\text { Nível } \\
4-200 \\
\text { a } 225 \\
\text { (cont.) }\end{array}$ & $\begin{array}{l}\text { resolvem problemas envolvendo subtração, estabelecendo relação entre di- } \\
\text { ferentes unidades monetárias; } \\
\text { resolvem situação-problema envolvendo: } \\
\text { aidéia de porcentagem; } \\
\text { diferentes significados da adição e subtração; } \\
\text { adição de números racionais na forma decimal; } \\
\text { identificam propriedades comuns e diferenças entre poliedros e corpos re- } \\
\text { dondos, relacionando figuras tridimensionais com suas planificações. }\end{array}$ \\
\hline $\begin{array}{l}\text { Nível } 5 \\
-225 \text { a } \\
250\end{array}$ & $\begin{array}{l}\text { Os alunos do } 5^{\circ} \text { e do } 9^{\circ} \text { anos, além das habilidades já descritas: } \\
\text { identificam a localização movimentação de objeto em mapas, desenhado em } \\
\text { malha quadriculada; } \\
\text { reconhecem e utilizam as regras do sistema de numeração decimal, tais como } \\
\text { agrupamentos e trocas na base } 10 \text { e o princípio do valor posicional; } \\
\text { calculam o resultado de uma adição por meio de uma técnica operatória; } \\
\text { lêem informações e dados apresentados em tabelas; } \\
\text { resolvem problema envolvendo o cálculo do perímetro de figuras planas, de- } \\
\text { senhadas em malhas quadriculadas; } \\
\text { resolvem problemas: } \\
\text { utilizando a escrita decimal de cédulas e moedas do sistema monetário bra- } \\
\text { sileiro; } \\
\text { estabelecendo trocas entre cédulas e moedas do sistema monetário brasi- } \\
\text { leiro, em função de seus valores; } \\
\text { com números racionais expressos na forma decimal, envolvendo diferentes } \\
\text { significados da adição ou subtração; } \\
\text { reconhecem a composição e decomposição de números naturais, na forma } \\
\text { polinomial; } \\
\text { identificam a divisão como a operação que resolve uma dada si- } \\
\text { tuaçãoproblema; } \\
\text { identificam a localização de números racionais na reta numérica. Os alunos } \\
\text { do 9a ano ainda: } \\
\text { identificam a localização/movimentação de objeto em mapas e outras re- } \\
\text { presentações gráficas; } \\
\text { lêem informações e dados apresentados em gráficos de colunas; } \\
\text { conseguem localizar dados em tabelas de múltiplas entradas; }\end{array}$ \\
\hline
\end{tabular}




\begin{tabular}{|c|c|}
\hline $\begin{array}{l}\text { Níveis de } \\
\text { Desempe- } \\
\text { nho dos } \\
\text { alunos em } \\
\text { Matemática }\end{array}$ & que os alunos conseguem fazer nesse nível e exemplos de competência \\
\hline $\begin{array}{l}\text { Nivel } \\
5-225 \\
\text { a } 250 \\
\text { (cont.) }\end{array}$ & $\begin{array}{l}\text { associam informações apresentadas em listas ou tabelas ao gráfico que as } \\
\text { representam e vice-versa; } \\
\text { identificam propriedades comuns e diferenças entre poliedros e corpos re- } \\
\text { dondos, relacionando figuras tridimensionais com suas planificações; } \\
\text { resolvem problemas envolvendo noções de porcentagem. }\end{array}$ \\
\hline $\begin{array}{l}\text { Nível } 6 \\
-250 \text { a } \\
275\end{array}$ & $\begin{array}{l}\text { O s alunos do } 5^{\circ} \text { e } 9^{\circ} \text { anos: } \\
\text { lidentifcam planificações de uma figura tridimensional; } \\
\text { resolvem problemas: } \\
\text { estabelecendo trocas entre cédulas e moedas do sistema monetário brasi- } \\
\text { leiro, em função de seus valores; } \\
\text { envolvendo diferentes significados da adição e subtração; } \\
\text { envolvendo o cálculo de área de figura plana, desenhada em malha } \\
\text { quadriculada; } \\
\text { reconhecem a decomposição de números naturais nas suas diversas ordens; } \\
\text { Identificam a localização de números racionais representados na forma de- } \\
\text { cimal na reta numérica; } \\
\text { estabelecem relação entre unidades de medida de tempo; } \\
\text { lêem tabelas comparando medidas de grandezas; } \\
\text { identificam propriedades comuns e diferenças entre figuras bidimensionais } \\
\text { pelo número de lados e pelos tipos de ângulos; } \\
\text { reconhecem a composição e decomposição de números naturais em sua } \\
\text { forma } \\
\text { polinomial. } \\
\text { Os alunos do 9o ano também: } \\
\text { reconhecem as representações decimais dos números racionais como uma } \\
\text { extensão do sistema de numeração decimal, identificando a existência de } \\
\text { "ordens" como décimos, centésimos e milésimos; } \\
\text { identificam a localização de números inteiros na reta numérica. }\end{array}$ \\
\hline $\begin{array}{l}\text { Nível } 7 \\
-275 \text { a } \\
300\end{array}$ & $\begin{array}{l}\text { Os alunos do } 5^{\circ} \text { e } 9^{\circ} \text { anos: } \\
\text { resolvem problemas com números naturais envolvendo diferentes significa- } \\
\text { dos da multiplicação e divisão, em situação combinatória; } \\
\text { reconhecem a conservação ou modificação de medidas dos lados, do } \\
\text { perímetro, da área em ampliação e/ou redução de figuras poligonais usando } \\
\text { malhas quadriculadas; }\end{array}$ \\
\hline
\end{tabular}




\begin{tabular}{|c|c|}
\hline $\begin{array}{l}\text { Níveis de } \\
\text { Desempe- } \\
\text { nho dos } \\
\text { alunos em } \\
\text { Matemática }\end{array}$ & O que os alunos conseguem fazer nesse nível e exemplos de competência \\
\hline 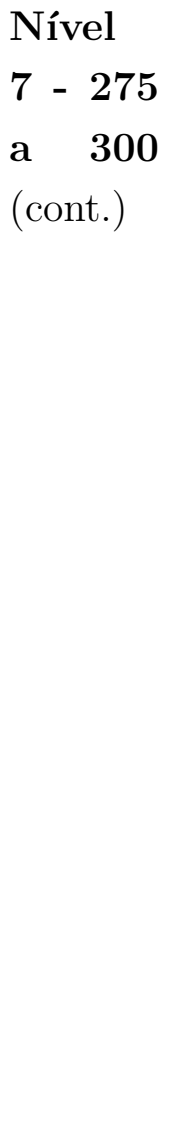 & $\begin{array}{l}\text { identificam propriedades comuns e diferenças entre figuras bidimensionais } \\
\text { pelo número de lados e tipos de ângulos; } \\
\text { identificam as posições dos lados de quadriláteros (paralelismo); } \\
\text { resolvem problemas: } \\
\text { utilizando divisão com resto diferente de zero; } \\
\text { com apoio de recurso gráfico, envolvendo noções de porcentagem; } \\
\text { estimam medida de grandezas utilizando unidades de medida convencionais } \\
\text { ou não; } \\
\text { estabelecem relações entre unidades de medida de tempo; } \\
\text { calculam o resultado de uma divisão por meio de uma técnica operatória; } \\
\text { No 9o ano: } \\
\text { identificam a localização/movimentação de objeto em mapas; } \\
\text { resolvem problema com números naturais, inteiros e racionais envolvendo } \\
\text { diferentes operações (adição, subtração, multiplicação, divisão, poten- } \\
\text { ciação); } \\
\text { calculam o valor numérico de uma expressão algébrica, incluindo poten- } \\
\text { ciação; } \\
\text { interpretam informações apresentadas por meio de coordenadas cartesianas; } \\
\text { identificam um sistema de equações do } 1^{\circ} \text { grau que expressa um problema }\end{array}$ \\
\hline $\begin{array}{ll}\text { Nível } & 8 \\
-300 \quad a \\
325\end{array}$ & $\begin{array}{l}\text { Os alunos do } 5^{\circ} \text { e do } 9^{\circ} \text { anos: } \\
\text { resolvem problemas; } \\
\text { envolvendo o cálculo do perímetro de figuras planas; } \\
\text { desenhadas em malhas quadriculadas; } \\
\text { envolvendo o cálculo de área de figuras planas, desenhadas em malha } \\
\text { quadriculada; } \\
\text { utilizando porcentagem; } \\
\text { utilizando unidades de medida padronizadas como } \mathrm{km} / \mathrm{m} / \mathrm{cm} / \mathrm{mm} \text {, } \\
\text { kg/g/mg, l/ml; } \\
\text { com números racionais expressos na forma decimal, envolvendo operações } \\
\text { de adição e subtração; } \\
\text { estimam a medida de grandezas utilizando unidades de medida convencio- } \\
\text { nal ou não; } \\
\text { lêem informações e dados apresentados em gráficos de coluna; }\end{array}$ \\
\hline
\end{tabular}




\begin{tabular}{|c|c|}
\hline $\begin{array}{l}\text { Níveis de } \\
\text { Desempe- } \\
\text { nho dos } \\
\text { alunos em } \\
\text { Matemática }\end{array}$ & O que os alunos conseguem fazer nesse nível e exemplos de competência \\
\hline $\begin{array}{l}\text { Nível } \\
8 \quad-300 \\
\text { a } \quad 325 \\
\text { (cont.) }\end{array}$ & $\begin{array}{l}\text { identificam a localização de números racionais representados na forma de- } \\
\text { cimal na reta numérica. }\end{array}$ \\
\hline $\begin{array}{l}\text { Nível } 9 \\
-325 \text { a } \\
350\end{array}$ & $\begin{array}{l}\text { Neste nível, os alunos do } 5^{\circ} \text { e } 9^{\circ} \text { anos: reconhecem a conservação ou mo- } \\
\text { dificação de medidas dos lados, do perímetro, da área em ampliação e/ou } \\
\text { redução de figuras poligonais usando malhas quadriculadas; } \\
\text { identificam fração como representação que pode estar associada a diferentes } \\
\text { significados; } \\
\text { resolvem equações do } 1^{\circ} \text { grau com uma incógnita; } \\
\text { identificam diferentes representações de um mesmo número racional; } \\
\text { calculam a área de um polígono desenhado em malha quadriculada; } \\
\text { reconhecem a representação numérica de uma fração a partir do preenchi- } \\
\text { mento de partes de uma figura. } \\
\text { No } 9^{\circ} \text { ano os alunos também: } \\
\text { reconhecem círculo/circunferência, seus elementos e algumas de suas } \\
\text { relações; } \\
\text { realizam conversão e somas de medidas de comprimento; } \\
\text { identificam a expressão algébrica que expressa uma regularidade observada } \\
\text { em seqüências de números ou figuras; } \\
\text { resolvem problemas utilizando relações entre diferentes unidades de medida; } \\
\text { resolvem problemas que envolvam equação do } 2^{\circ} \text { grau; } \\
\text { identificam fração como representação que pode estar associada a diferentes } \\
\text { significados; } \\
\text { resolvem problemas: } \\
\text { envolvendo a escrita decimal de cédulas e moedas do sistema monetário } \\
\text { brasileiro, utilizando várias operações (adição, subtração, multiplicação e } \\
\text { divisão); } \\
\text { utilizando as relações métricas do triângulo retângulo; } \\
\text { reconhecem que as imagens de uma figura construída por uma trans- } \\
\text { formação homotética são semelhantes, identificando propriedades e/ou me- } \\
\text { didas que se modificam ou não se alteram. }\end{array}$ \\
\hline
\end{tabular}




\begin{tabular}{|c|c|}
\hline $\begin{array}{l}\text { Níveis de } \\
\text { Desempe- } \\
\text { nho dos } \\
\text { alunos em } \\
\text { Matemática }\end{array}$ & O que os alunos conseguem fazer nesse nível e exemplos de competência \\
\hline $\begin{array}{l}\text { Nivel } \\
10 \\
350 \\
375\end{array}$ & $\begin{array}{l}\text { Além das habilidades demonstradas nos níveis anteriores, neste nível, os } \\
\text { aluno do } 5^{\circ} \text { e } 9^{\circ} \text { anos: } \\
\text { estimam a medida de grandezas utilizando unidades de medida convencio- } \\
\text { nal ou não; } \\
\text { identificam propriedades comuns e diferenças entre poliedros e corpos re- } \\
\text { dondos, relacionando figuras tridimensionais com suas planificações; } \\
\text { calculam o resultado de uma multiplicação ou divisão de números naturais. } \\
\text { No } 9^{\circ} \text { ano os alunos também: resolvem problemas envolvendo: } \\
\text { o cálculo de área e perímetro de figuras planas; } \\
\text { o cálculo do perímetro de figuras planas, desenhadas em malha quadricu- } \\
\text { lada; } \\
\text { ângulos, inclusive utilizando a Lei Angular de Tales e utilizando o Teorema } \\
\text { de Pitágoras; } \\
\text { noções de volume; } \\
\text { relações métricas do triângulo retângulo a partir de apoio gráfico significa- } \\
\text { tivo; } \\
\text { reconhecem as diferentes representações de um número racional; } \\
\text { estabelecem relação entre frações próprias e impróprias, as suas repre- } \\
\text { sentações decimais, assim como localizam-nas na reta numérica; } \\
\text { efetuam cálculos simples com valores aproximados de radicais; } \\
\text { identificam uma equação ou inequação do } 1^{\circ} \text { grau que expressa um pro- } \\
\text { blema; } \\
\text { interpretam informações apresentadas por meio de coordenadas cartesianas; } \\
\text { reconhecem as representações dos números racionais como uma extensão do } \\
\text { sistema de numeração decimal, identificando a existência de "ordens" como } \\
\text { décimos, centésimos e milésimos; } \\
\text { identificam relação entre quadriláteros por meio de suas propriedades; } \\
\text { efetuam cálculos com números inteiros, envolvendo as operações (adição; } \\
\text { subtração; multiplicação; divisão e potenciação); } \\
\text { identificam quadriláteros observando as posições relativas entre seus lados } \\
\text { (paralelos, concorrentes, perpendiculares); } \\
\text { identificam frações equivalentes; } \\
\text { efetuam somatório e cálculo de raiz quadrada; }\end{array}$ \\
\hline
\end{tabular}




\begin{tabular}{|c|c|}
\hline $\begin{array}{l}\text { Níveis de } \\
\text { Desempe- } \\
\text { nho dos } \\
\text { alunos em } \\
\text { Matemática }\end{array}$ & O que os alunos conseguem fazer nesse nível e exemplos de competência \\
\hline $\begin{array}{l}\text { Nivel } \\
10 \\
350 \\
\text { a } \quad 375 \\
\text { (cont.) }\end{array}$ & $\begin{array}{l}\text { identificam as medidas que não se alteram (ângulos) e as que se modificam } \\
\text { (perímetro, lados e área) em transformações (ampliações ou reduções) de } \\
\text { figuras poligonais usando malhas quadriculadas; } \\
\text { reconhecem ângulos como mudança de direção ou giros, identificando } \\
\text { ângulos retos e não-retos. }\end{array}$ \\
\hline $\begin{array}{l}\text { Nível } \\
11 \\
375 \\
400\end{array}$ & $\begin{array}{l}\text { Além das habilidades demonstradas nos níveis anteriores, neste nível os alu- } \\
\text { nos do } 9^{\circ} \text { ano: } \\
\text { reconhecem círculo/circunferência, seus elementos e algumas de suas } \\
\text { relações; } \\
\text { identificam propriedades de triângulos pela comparação de medidas de la- } \\
\text { dos e ângulos; } \\
\text { efetuam operações com números racionais, envolvendo a utilização de } \\
\text { parênteses (adição, subtração, multiplicação, divisão, potenciação); } \\
\text { reconhecem expressão algébrica que representa uma função a partir de uma } \\
\text { tabela; } \\
\text { reconhecem figuras semelhantes mediante o reconhecimento de relações de } \\
\text { proporcionalidade; } \\
\text { identificam: } \\
\text { a localização de números racionais na reta numérica; } \\
\text { propriedades de triângulos pela comparação de medidas de lados e ângulos; } \\
\text { propriedades comuns e diferenças entre figuras bidimensionais e tridimen- } \\
\text { sionais, relacionando-as com as suas planificações; } \\
\text { a relação entre as representações algébrica e geométrica de um sistema de } \\
\text { equações do 1o grau; } \\
\text { resolvem problemas: } \\
\text { envolvendo noções de volume; } \\
\text { envolvendo porcentagem; } \\
\text { utilizando propriedades dos polígonos (soma de seus ângulos internos, } \\
\text { número de diagonais, cálculo da medida de cada ângulo interno nos } \\
\text { polígonos regulares); } \\
\text { utilizando relações métricas do triângulo retângulo; } \\
\text { interpretando informações apresentadas em tabelas e/ou gráficos. }\end{array}$ \\
\hline
\end{tabular}




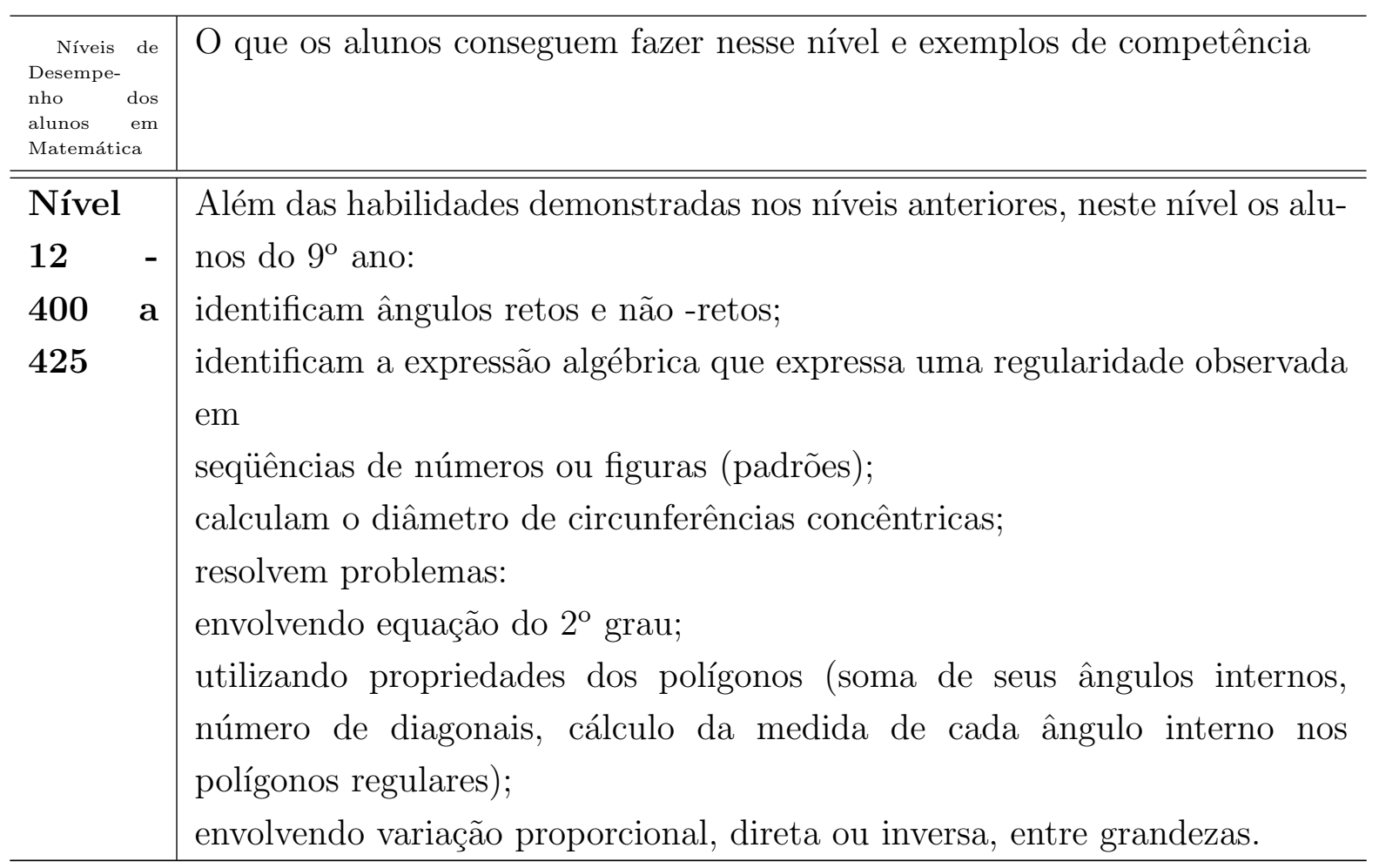


Apêndice $B$

Apêndice 
Apêndice B. Apêndice

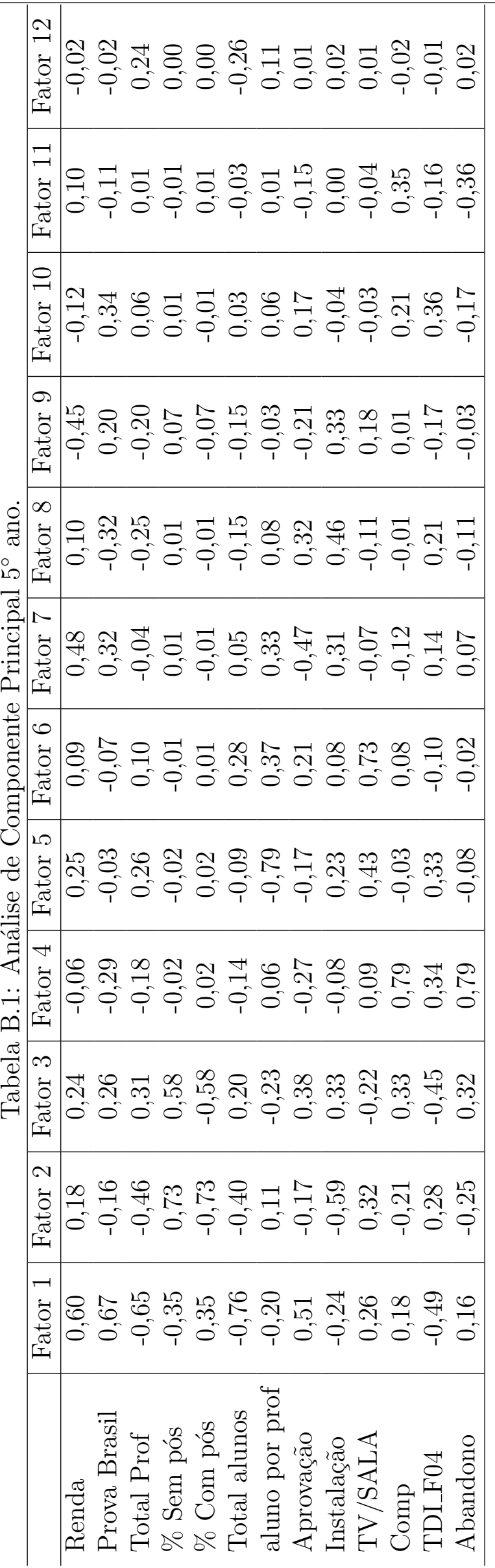

\begin{tabular}{|c|c|}
\hline 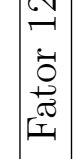 & 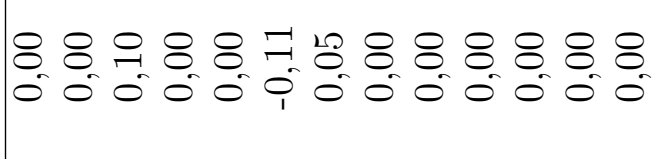 \\
\hline 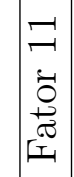 & 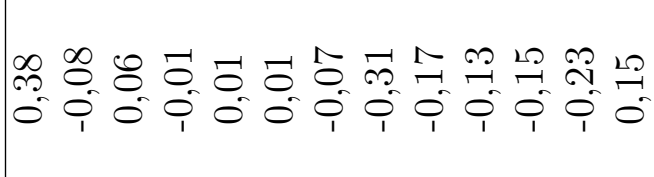 \\
\hline $\begin{array}{l}\overrightarrow{0} \\
0 \\
0\end{array}$ & 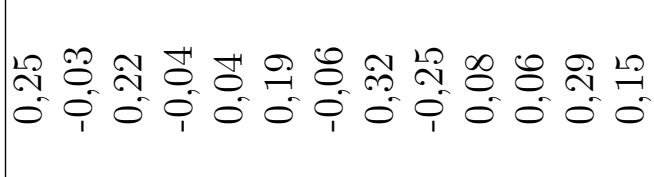 \\
\hline 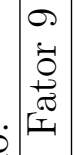 & 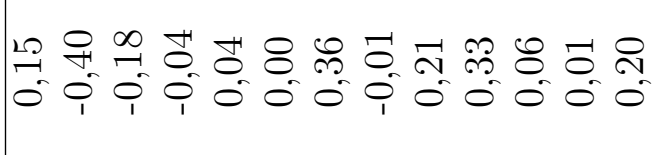 \\
\hline 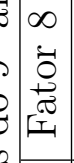 & 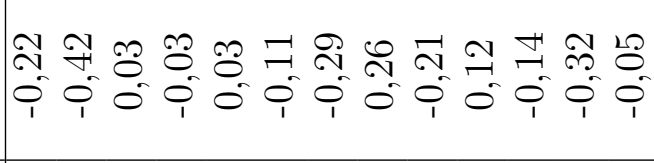 \\
\hline 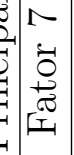 & 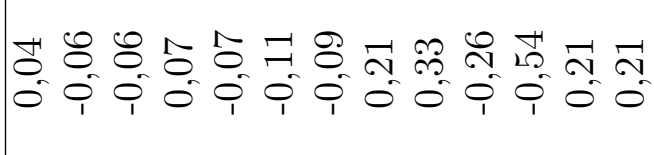 \\
\hline 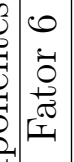 & 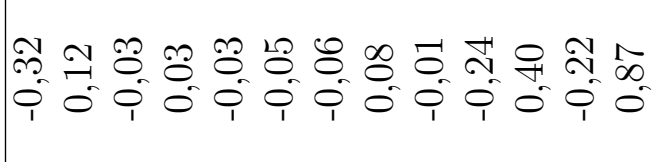 \\
\hline 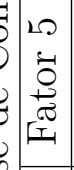 & 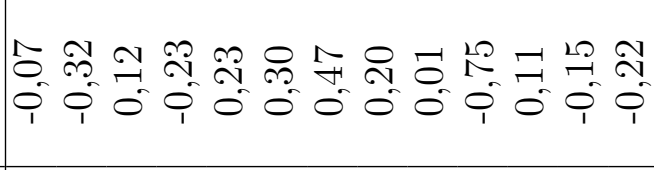 \\
\hline 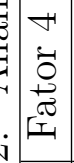 & 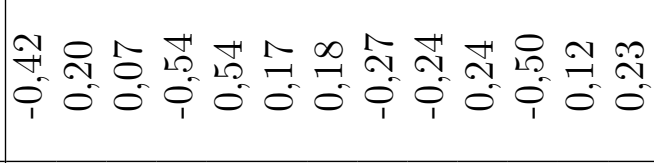 \\
\hline 垔 & 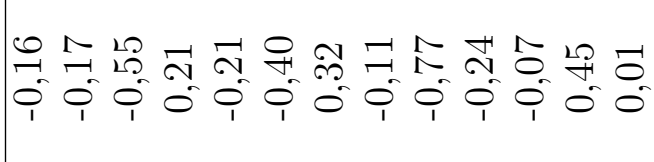 \\
\hline 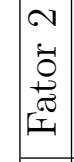 & 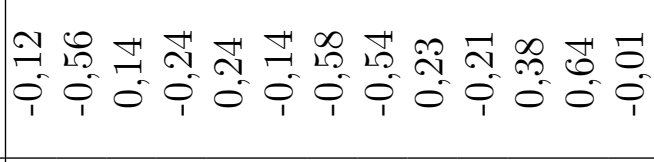 \\
\hline 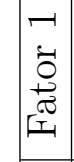 & $\begin{array}{llllllllllll}1 & 1 & 0 & 0 & 0 & 1 & 0 & 0 & 0 & 0 \\
0 & 0 & 0 & 0\end{array}$ \\
\hline & 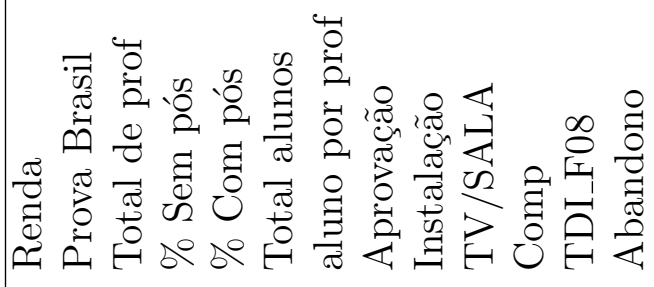 \\
\hline
\end{tabular}




\begin{tabular}{|c|c|c|c|c|}
\hline 我 & 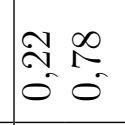 & 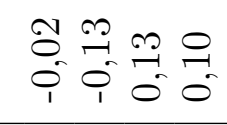 & :̊. & 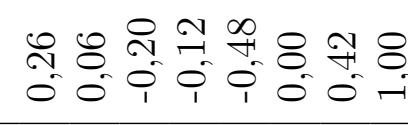 \\
\hline & 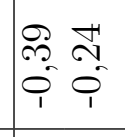 & 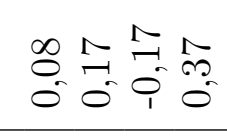 & $\begin{array}{l}\overrightarrow{0} \\
\sigma_{0} \\
0\end{array}$ & 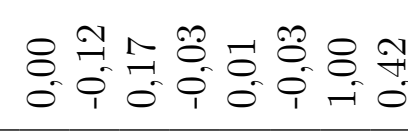 \\
\hline$\frac{\pi}{4}$ & {$\left[\begin{array}{ll}\approx & 4 \\
0 & 0 \\
0 & 0\end{array}\right.$} & 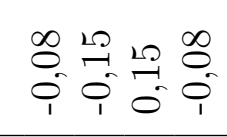 & si & 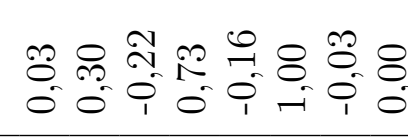 \\
\hline & 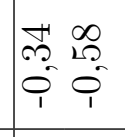 & 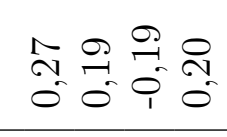 & $\begin{array}{l}8 \\
0 \\
i\end{array}$ & 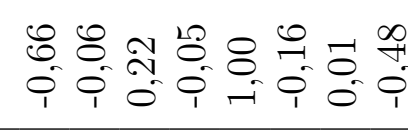 \\
\hline ठั & 在 & $\begin{array}{l}8.50 \\
0.00 \\
i=0 \\
\end{array}$ & $\ddot{0}$ & 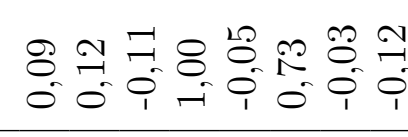 \\
\hline & 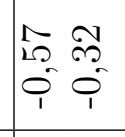 & 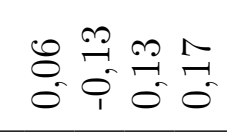 & ָֻ & 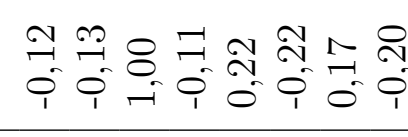 \\
\hline & 弪 : & 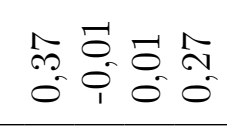 & $\stackrel{\infty}{c_{i}^{+}}$ & 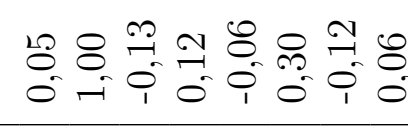 \\
\hline & 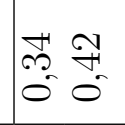 & 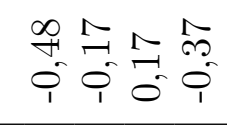 & Fे & 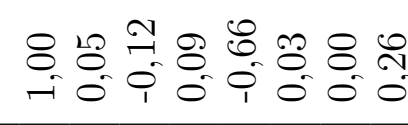 \\
\hline & 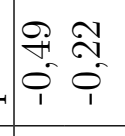 & 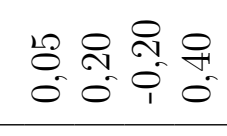 & $\stackrel{8}{-}$ & 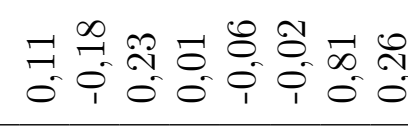 \\
\hline & $\begin{array}{ll}0 \\
0 \\
0 & 7 \\
i & 0 \\
1 & 0 \\
\end{array}$ & 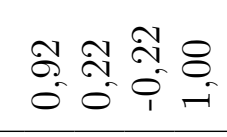 & 욤 & \\
\hline & 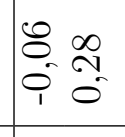 & 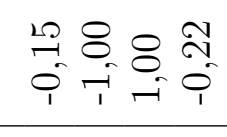 & क्षे & 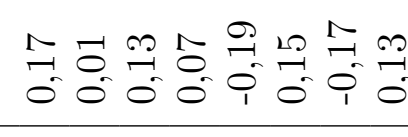 \\
\hline & $\mid \begin{array}{ll}0 & \infty \\
0 & 0 \\
0 & 0 \\
0 & 0\end{array}$ & 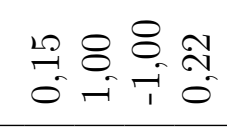 & वิ & 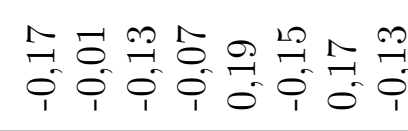 \\
\hline 吾崖 & $\begin{array}{ll}2 & \infty \\
0 & \infty \\
1 & 0 \\
1 & 0\end{array}$ & 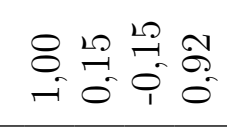 & $\stackrel{8}{\circ}$ & 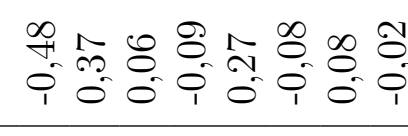 \\
\hline 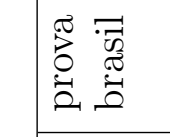 & 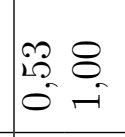 & 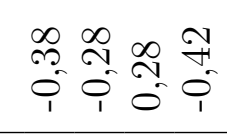 & $\begin{array}{l}\text { Nิ } \\
\text { î } \\
\end{array}$ & 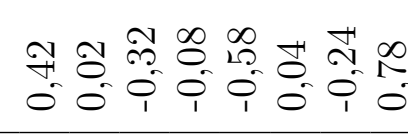 \\
\hline 苋 & 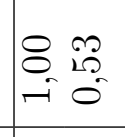 & 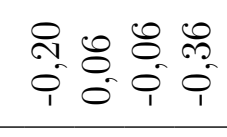 & $\begin{array}{l}\text { क्ष } \\
\text { i }\end{array}$ & 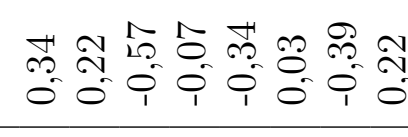 \\
\hline & 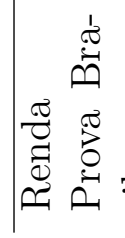 & 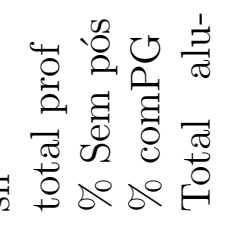 & $\stackrel{\ddot{\circ}}{\stackrel{2}{2}}$ & 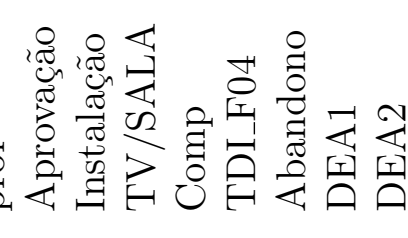 \\
\hline
\end{tabular}




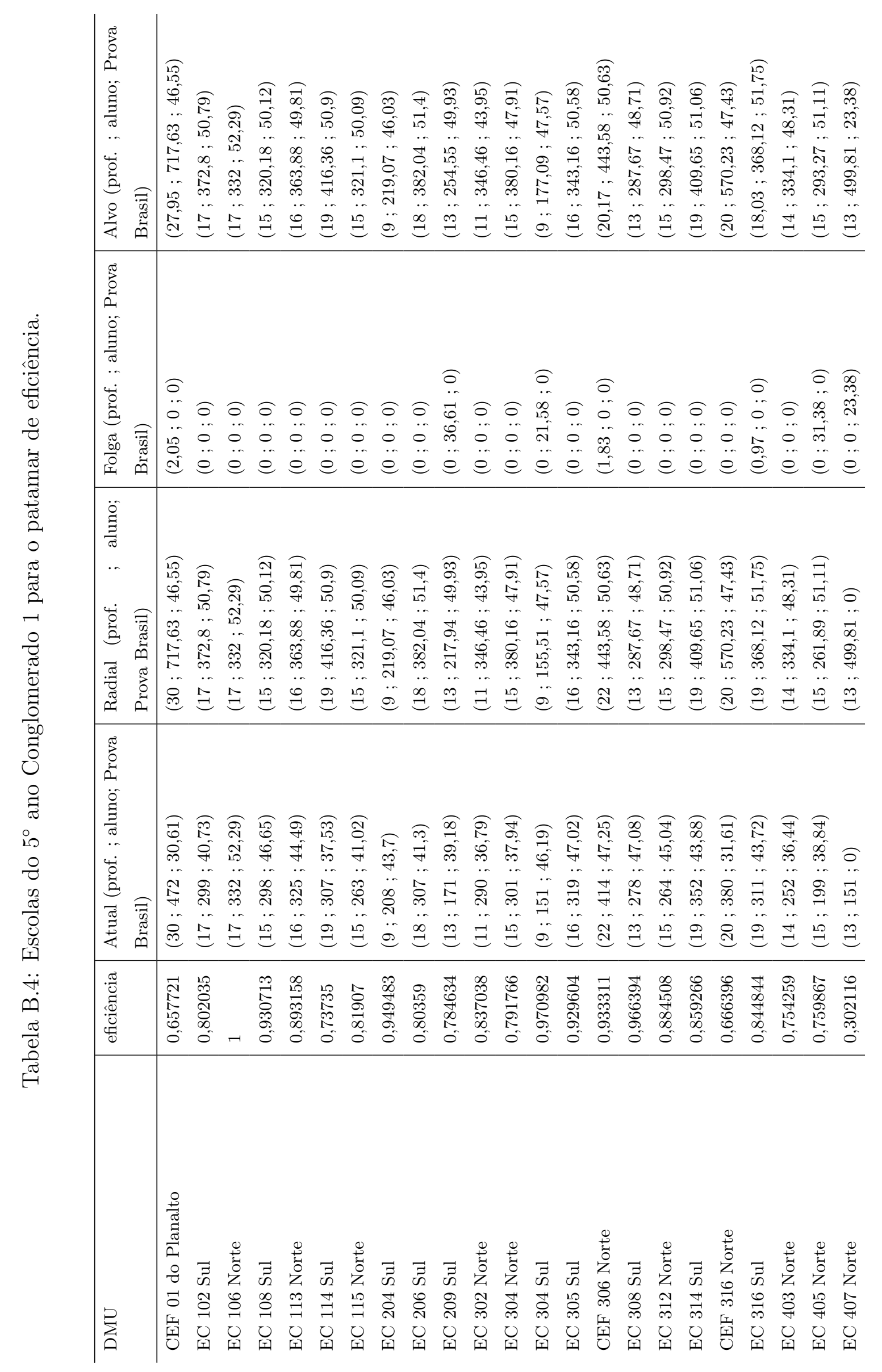




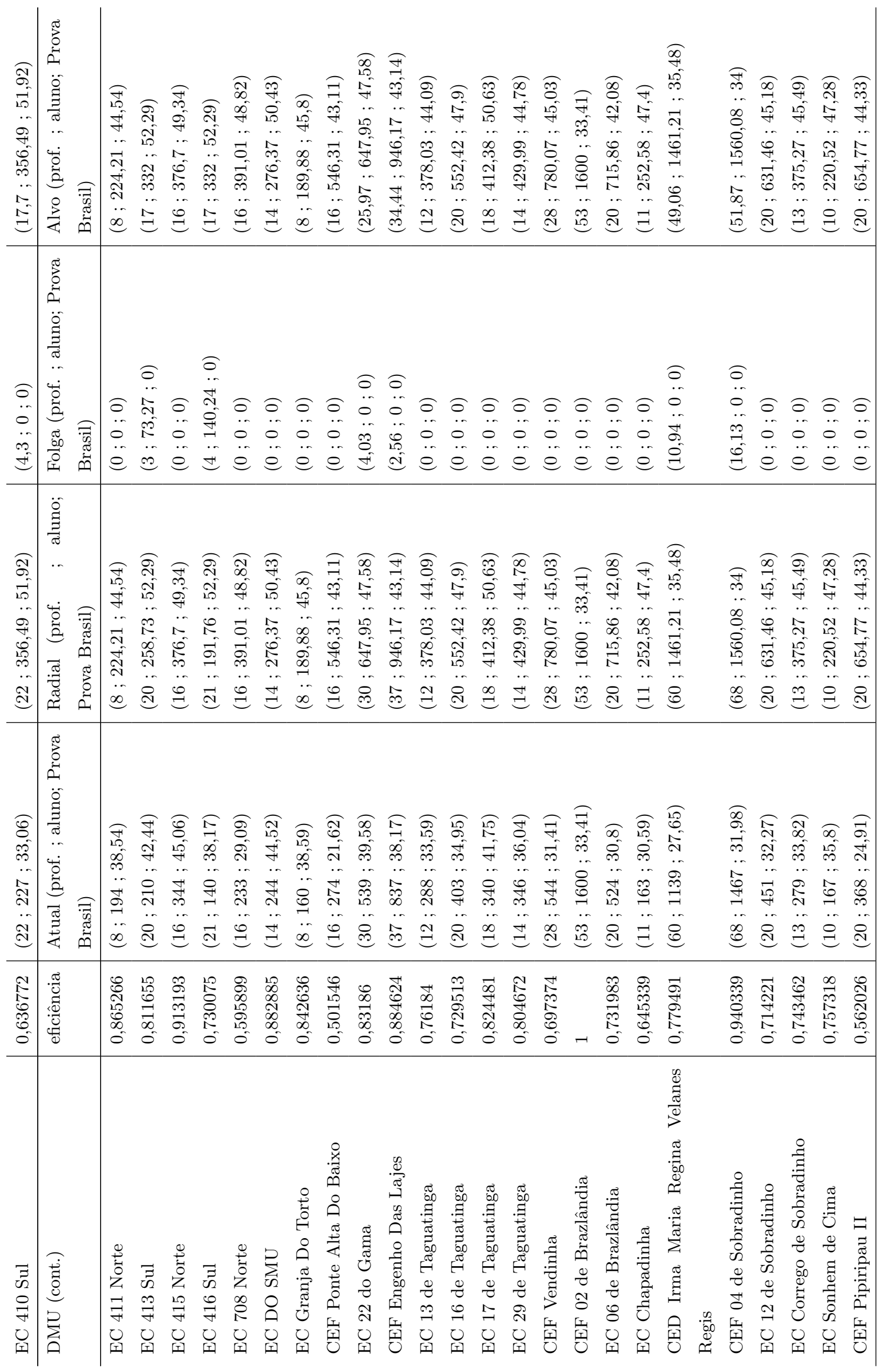




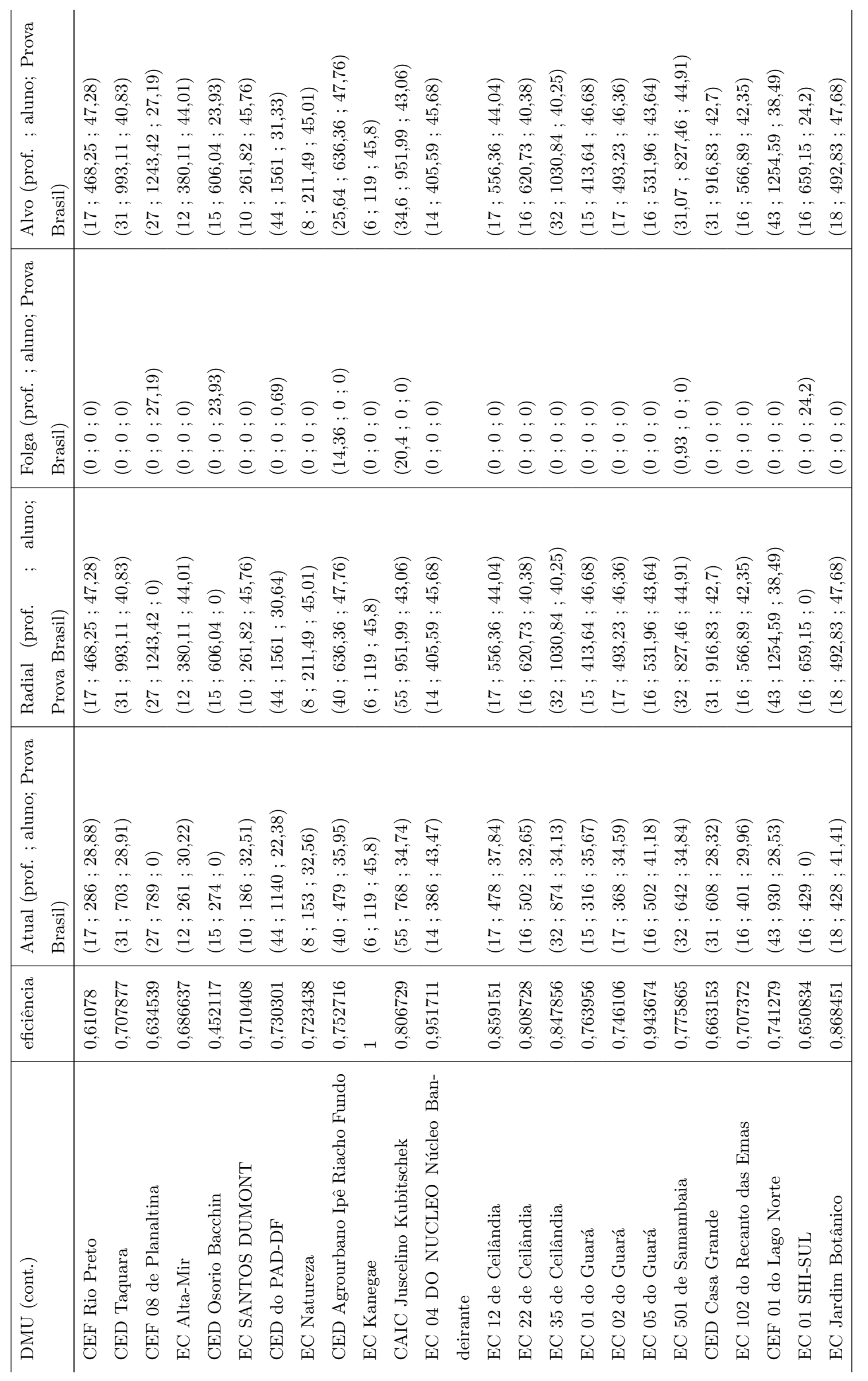




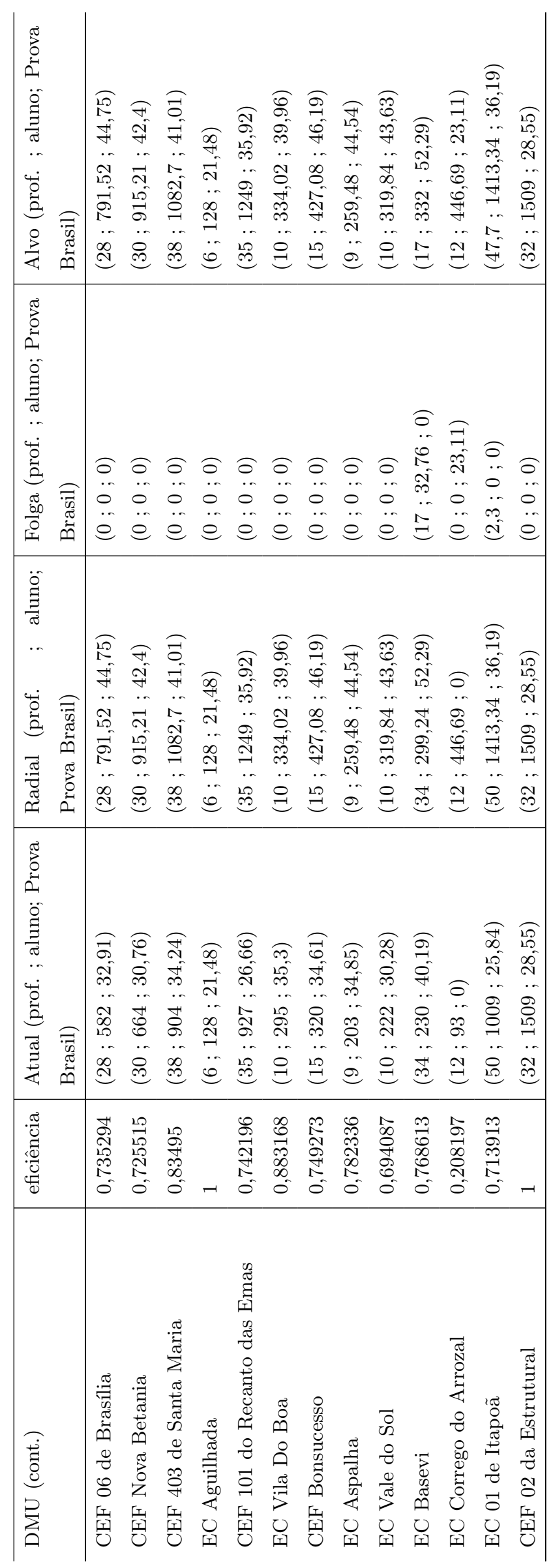


Tabela B.6: Escolas Eficientes segundo Escolas $5^{\circ}$ ano Conglomerado 1.

\begin{tabular}{|c|c|c|c|c|c|}
\hline $\mathrm{DMU}$ & $\begin{array}{ll}\text { EC } & 106 \\
\text { Norte } & \end{array}$ & $\begin{array}{l}\text { CEF } \\
02 \quad \text { DE } \\
\text { Brazlândia }\end{array}$ & $\begin{array}{l}\text { EC Kane- } \\
\text { gae }\end{array}$ & $\begin{array}{l}\text { EC Agui- } \\
\text { lhada }\end{array}$ & $\begin{array}{l}\text { CEF } 02 \text { da } \\
\text { Estrutural }\end{array}$ \\
\hline CEF 01 do Planalto & 0,695876 & 0,304124 & 0 & 0 & 0 \\
\hline EC $102 \mathrm{Sul}$ & 0,891218 & 0 & 0,062759 & 0 & 0,046023 \\
\hline EC 106 Norte & 1 & 0 & 0 & 0 & 0 \\
\hline EC 108 Sul & 0,746431 & 0 & 0,223213 & 0 & 0,030356 \\
\hline EC 113 Norte & 0,772476 & 0 & 0,169725 & 0 & 0,057799 \\
\hline EC 114 Sul & 0,931934 & 0,04662 & 0 & 0 & 0,021446 \\
\hline EC 115 Norte & 0,744002 & 0 & 0,224614 & 0 & 0,031384 \\
\hline EC $204 \mathrm{Sul}$ & 0,160815 & 0 & 0,791837 & 0 & 0,047347 \\
\hline EC $206 \mathrm{Sul}$ & 0,958901 & 0,018262 & 0 & 0 & 0,022837 \\
\hline EC $209 \mathrm{Sul}$ & 0,636364 & 0 & 0,363636 & 0 & 0 \\
\hline EC 302 Norte & 0,106239 & 0 & 0,7464 & 0 & 0,14736 \\
\hline EC 304 Norte & 0,586522 & 0 & 0,315468 & 0 & 0,09801 \\
\hline EC $304 \mathrm{Sul}$ & 0,272727 & 0 & 0,727273 & 0 & 0 \\
\hline EC $305 \mathrm{Sul}$ & 0,827719 & 0 & 0,137854 & 0 & 0,034427 \\
\hline CEF 306 Norte & 0,912002 & 0,087998 & 0 & 0 & 0 \\
\hline EC $308 \mathrm{Sul}$ & 0,548057 & 0 & 0,414583 & 0 & 0,037361 \\
\hline EC 312 Norte & 0,804322 & 0 & 0,189814 & 0 & 0,005864 \\
\hline EC $314 \mathrm{Sul}$ & 0,937963 & 0,050926 & 0 & 0 & 0,011112 \\
\hline CEF 316 Norte & 0,792451 & 0 & 0,004355 & 0 & 0,203194 \\
\hline EC $316 \mathrm{Sul}$ & 0,971518 & 0,028482 & 0 & 0 & 0 \\
\hline EC 403 Norte & 0,56679 & 0 & 0,365314 & 0 & 0,067897 \\
\hline EC 405 Norte & 0,818182 & 0 & 0,181818 & 0 & 0 \\
\hline EC 407 Norte & 0 & 0 & 0 & 0,730769 & 0,269231 \\
\hline EC $410 \mathrm{Sul}$ & 0,98069 & 0,01931 & 0 & 0 & 0 \\
\hline EC 411 Norte & 0,004571 & 0 & 0,92044 & 0 & 0,074989 \\
\hline EC $413 \mathrm{Sul}$ & 1 & 0 & 0 & 0 & 0 \\
\hline EC 415 Norte & 0,738289 & 0 & 0,189449 & 0 & 0,072263 \\
\hline EC $416 \mathrm{Sul}$ & 1 & 0 & 0 & 0 & 0 \\
\hline EC 708 Norte & 0,700148 & 0 & 0,211453 & 0 & 0,088399 \\
\hline EC DO SMU & 0,720721 & 0 & 0,276507 & 0 & 0,002772 \\
\hline EC Granja do Torto & 0,096094 & 0 & 0,867638 & 0 & 0,036268 \\
\hline CEF Ponte Alta do Baixo & 0,286087 & 0 & 0,450334 & 0 & 0,263579 \\
\hline EC 22 do Gama & 0,750832 & 0,249168 & 0 & 0 & 0 \\
\hline CEF Engenho das Lajes & 0,515643 & 0,484357 & 0 & 0 & 0 \\
\hline EC 13 de Taguatinga & 0,164599 & 0 & 0,67427 & 0 & 0,161131 \\
\hline EC 16 de Taguatinga & 0,813468 & 0,00962 & 0 & 0 & 0,176911 \\
\hline EC 17 de Taguatinga & 0,928231 & 0 & 0,002944 & 0 & 0,068825 \\
\hline
\end{tabular}




\begin{tabular}{|c|c|c|c|c|c|}
\hline EC 29 de Taguatinga & 0,311146 & 0 & 0,512801 & 0 & 0,176054 \\
\hline DMU (cont.) & $\begin{array}{ll}\text { EC } & 106 \\
\text { Norte }\end{array}$ & $\begin{array}{l}\text { CEF } \\
02 \quad \text { DE } \\
\text { Brazlândia }\end{array}$ & $\begin{array}{l}\text { EC Kane- } \\
\text { gae }\end{array}$ & $\begin{array}{l}\text { EC Agui- } \\
\text { lhada }\end{array}$ & $\begin{array}{l}\text { CEF } 02 \text { da } \\
\text { Estrutural }\end{array}$ \\
\hline CEF Vendinha & 0,639926 & 0,266613 & 0 & 0 & 0,093461 \\
\hline CEF 02 de Brazlândia & 0 & 1 & 0 & 0 & 0 \\
\hline EC 06 de Brazlândia & 0,404179 & 0 & 0,228358 & 0 & 0,367463 \\
\hline EC Chapadinha & 0,356533 & 0 & 0,602 & 0 & 0,041467 \\
\hline $\begin{array}{l}\text { CED Irmã Maria Regina Velanes } \\
\text { Regis }\end{array}$ & 0,109456 & 0,890544 & 0 & 0 & 0 \\
\hline CEF 04 de Sobradinho & 0,031486 & 0,968514 & 0 & 0 & 0 \\
\hline EC 12 de Sobradinho & 0,629217 & 0 & 0,098529 & 0 & 0,272254 \\
\hline EC Corrego de Sobradinho & 0,314494 & 0 & 0,54933 & 0 & 0,136176 \\
\hline EC Sonhem de Cima & 0,299488 & 0 & 0,673372 & 0 & 0,02714 \\
\hline CEF Pipiripau II & 0,567052 & 0 & 0,134393 & 0 & 0,298555 \\
\hline CEF Rio Preto & 0,636731 & 0 & 0,209578 & 0 & 0,153691 \\
\hline CED Taquara & 0,460033 & 0,280976 & 0 & 0 & 0,258991 \\
\hline CEF 08 de Planaltina & 0 & 0 & 0 & 0,192308 & 0,807692 \\
\hline EC Alta-Mir & 0,159049 & 0 & 0,677472 & 0 & 0,163479 \\
\hline CED Osorio Bacchin & 0 & 0 & 0 & 0,653846 & 0,346154 \\
\hline EC Santos Dumont & 0,18936 & 0 & 0,736908 & 0 & 0,073732 \\
\hline CED do PAD-DF & 0 & 0,571429 & 0 & 0 & 0,428571 \\
\hline EC Natureza & 0,03848 & 0 & 0,900877 & 0 & 0,060643 \\
\hline $\begin{array}{l}\text { CED Agrourbano Ipe Riacho } \\
\text { Fundo }\end{array}$ & 0,759967 & 0,240033 & 0 & 0 & 0 \\
\hline EC Kanegae & 0 & 0 & 1 & 0 & 0 \\
\hline CAIC Juscelino Kubitschek & 0,511047 & 0,488953 & 0 & 0 & 0 \\
\hline EC 04 do Núcleo Bandeirante & 0,376209 & 0 & 0,475264 & 0 & 0,148527 \\
\hline EC 12 de Ceilândia & 0,401821 & 0 & 0,345103 & 0 & 0,253076 \\
\hline EC 22 de Ceilândia & 0,087682 & 0 & 0,564799 & 0 & 0,347519 \\
\hline EC 35 de Ceilândia & 0,430004 & 0,307145 & 0 & 0 & 0,262851 \\
\hline EC 01 do Guará & 0,497278 & 0 & 0,366955 & 0 & 0,135767 \\
\hline EC 02 do Guará & 0,570148 & 0 & 0,247992 & 0 & 0,181861 \\
\hline EC 05 do Guará & 0,324339 & 0 & 0,428266 & 0 & 0,247395 \\
\hline EC 501 de Samambaia & 0,609256 & 0,390744 & 0 & 0 & 0 \\
\hline CED Casa Grande & 0,528628 & 0,329973 & 0 & 0 & 0,141399 \\
\hline EC 102 do Recanto das Emas & 0,231227 & 0 & 0,481984 & 0 & 0,286788 \\
\hline CEF 01 do Lago Norte & 0,271654 & 0,717848 & 0 & 0 & 0,010499 \\
\hline EC 01 SHI-SUL & 0 & 0 & 0 & 0,615385 & 0,384615 \\
\hline EC Jardim Botânico & 0,713738 & 0 & 0,12669 & 0 & 0,159572 \\
\hline CEF 06 de Brasília & 0,629628 & 0,259258 & 0 & 0 & 0,111113 \\
\hline CEF Nova Betania & 0,526188 & 0,28061 & 0 & 0 & 0,193202 \\
\hline CEF 403 de Santa Maria & 0,406746 & 0,576247 & 0 & 0 & 0,017008 \\
\hline
\end{tabular}




\begin{tabular}{l|l|l|l|l|l} 
EC Aguilhada & 0 & 0 & 0 & 1 & 0 \\
\hline DMU (cont.) & EC 106 & CEF & EC Kane- & EC Agui- & CEF 02 da \\
& Norte & $02 \quad$ DE & gae \\
lhada & Estrutural \\
\hline CEF 101 do Recanto das Emas & 0,245507 & 0,31822 & 0 & 0 & 0,436273 \\
EC Vila do Boa & 0 & 0 & 0,715203 & 0,130951 & 0,153846 \\
CEF Bonsucesso & 0,461434 & 0 & 0,387634 & 0 & 0,150932 \\
EC Aspalha & 0,05307 & 0 & 0,853998 & 0 & 0,092932 \\
EC Vale do Sol & 0,034664 & 0 & 0,826155 & 0 & 0,139181 \\
EC Basevi & 1 & 0 & 0 & 0 & 0 \\
EC Corrego do Arrozal & 0 & 0 & 0 & 0,769231 & 0,230769 \\
EC 01 de Itapoã & 0,14721 & 0,85279 & 0 & 0 & 0 \\
CEF 02 da Estrutural & 0 & 0 & 0 & 0 & 1 \\
\hline
\end{tabular}

